\title{
ipen
}

AUTARQUIA ASSOCIADA À UNIVERSIDADE DE SÃO PAULO

\section{AVALIAÇÃO DA MICROBIOTA FÚNGICA E DA PRESENÇA DE MICOTOXINAS EM AMOSTRAS DE PLANTAS MEDICINAIS IRRADIADAS ADQUIRIDAS NO COMÉRCIO VAREJISTAE ATACADISTA}

\section{SIMONE AQUINO}

Tese apresentada como parte dos requisitos para obtenção do Grau de Doutor em Ciências na Área de Tecnologia Nuclear - Aplicações.

Orientadora:

Dra. Anna Lucia C.H.Villavicencio 


\section{(c)}

INSTITUTO DE PESQUISAS ENERGÉTICAS E NUCLEARES Autarquia associada à Universidade de São Paulo

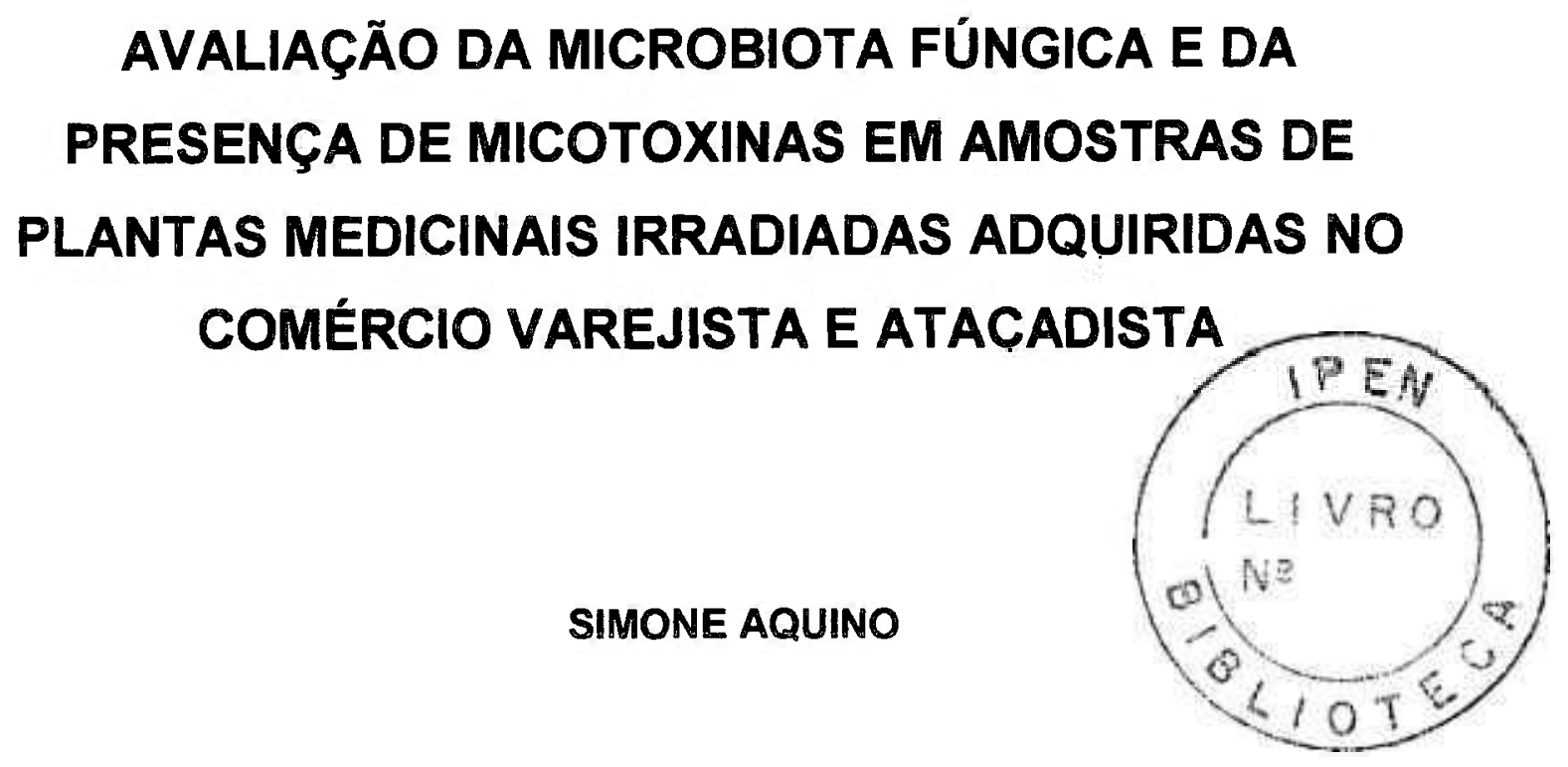

Tese apresentada como parte dos requisitos para obtenção do Grau de Doutor em Ciências na Área de Tecnologia Nuclear Aplicações.

Orientadora:

Dra. Anna Lucia C. H. Villavicencio 
À minha mãe Lúcia e meu pai Nei (in memoriam) pelo amor, incentivo e valorização dos estudos desde minha infância.

À minha familia, Wagner, Elaine, Rafael e Walter, por estarem ao meu lado em momentos cheios de obstáculos. 


\section{AGRADECIMENTOS}

À Dra. Anna Lucia C. H. Villavicencio por partilhar seus conhecimentos, amizade e, sobretudo me ensinar que determinação, persistência e força de vontade são as bases da busca cientifica.

Ao Prof. Dr. Benedito Corrêa por sua inestimável amizade, paciência e conselhos e me aceitar em seu grupo e me orientar como sua própria aluna.

Ao Instituto de Pesquisas Energéticas e Nucleares - IPEN-CNEN e CRTD, representado pelo Dr. Wilson Aparecido Parejo Calvo, pela oportunidade, apoio e financiamento em todas as etapas deste trabalho.

À MSc. Edlayne Gonçalez, Dra. Maria Helena Rossi, Dra. Joana D'arc Felicio, Dr. Marcos R. Potenza, Juliana H. C. Nogueira, pelos conselhos, orientações e desenvolvimento prático das análises realizadas no Instituto Biológico de São Paulo, fundamentais neste projeto.

À Dra. Sueli Borrely, Dr. Afonso R. Aquino e aos meus colegas Michel, Ingrid, Reginaldo, Vladimir, Thaise, Gustavo, Priscila e Rosamaria, pelo carinho $e$ amizade nos momentos de convivência no IPEN.

A Tatiana Alves dos Reis, Técnica do Laboratório de Micotoxinas do ICB II, pelo companheirismo e por ensinar as metodologias e execução das análises desenvolvidas neste trabalho.

Aos engenheiros Elizabeth Somessari e Carlos Gaia da Silveira, pelo carinho e por auxiliarem no processo de irradiação das amostras.

A Patrícia, Raquel, Mauro, Adriana, Ivyna, Fabiane, Daniele, Shirley, Viviane, Liliana, Aninha e Mônica Louvison pela amizade e convivência afetuosa no ICB II.

Ao CNPq pelo auxílio financeiro, sem o qual, não seria possível o desenvolvimento deste projeto.

A todos aqueles que, direta ou indiretamente, colaboraram para $\circ$ desenvolvimento e conclusão deste trabalho, os meus inestimáveis agradecimentos. 
"As pessoas que vencem neste mundo são as que procuram as circunstâncias de que precisame, quando não as encontram, as criam." Bernard Shaw 


\title{
AVALIAÇÃO DA MICROBIOTA FÚNGICA E DA PRESENÇA DE MICOTOXINAS EM AMOSTRAS DE PLANTAS MEDICINAIS IRRADIADAS ADQUIRIDAS NO COMÉRCIO VAREJISTA E ATACADISTA
}

\author{
SIMONE AQUINO
}

\section{RESUMO}

O presente estudo analisou os efeitos da radiação gama na sobrevivência de fungos em plantas medicinais embaladas, adquiridas do comércio atacadista e varejista, em diferentes períodos ( 0 e 30 dias) após o tratamento por iriadiação. Cinco tipos de plantas medicinais (Peumus boldus, Camellia sinensis, Maytenus ilicifolia, Paullinia cupana and Cassia angustifolia), foram coletadas de diferentes municípios do Estado de São Paulo e submetidas ao tratamento por irradiação, utilizando-se uma fonte ${ }^{60} \mathrm{Co}$ (tipo Gammacell 220), com doses de 5,0 kGy e $10 \mathrm{kGy}$ e taxa de dose de 3,0 $\mathrm{kGy} / \mathrm{h}$. Amostras não irradiadas (grupo controle) foram usadas na contagem de fungos e diluições seriadas de $10^{-1}$ a $10^{-6}$ das amostras foram semeadas em duplicata e plaqueadas usando o método de cultura em superfície, em ágar Dicloran Glicerol $18 \%$ (DG18) e contadas após cinco dias a $25^{\circ} \mathrm{C}$. O grupo controle revelou a presença dos gêneros Aspergillus e Penicillium, os quais são conhecidos como fungos toxigênicos e poucas amostras do grupo controle estavam dentro dos limites seguros, estabelecidos pela Organização Mundial de Saúde (OMS, 1998) para plantas medicinais. Em resposta a resistência do tratamento por ionização, na dose de $5 \mathrm{kGy}$, foi observado que os gêneros Aspergillus, Phoma e Syncephalastrum foram radiorresistentes, após o processo (dia 0 e $30^{\circ}$ dia). $O$ tratamento por radiação gama foi efetivo na descontaminação de todas as amostras de plantas medicinais, após 30 dias, com a dose de $10 \mathrm{kGy}$ e mantidas em condições de vedação. Não foram detectadas aflatoxinas nas amostras do grupo controle, ainda que estas amostras estivessem intensamente contaminadas com Aspergillus flavus. 


\title{
EVALUATION OF FUNGAL BIOBURDEN AND MICOTOXINS PRESENCE IN IRRADIATED SAMPLES OF MEDICINAL PLANTS PURCHASED FROM WHOLESALE AND RETAIL MARKET
}

\section{SIMONE AQUINO}

\begin{abstract}
This present study evaluated the effect of gamma radiation on the fungal survival in packed medicinal plants, purchased from wholesale and retail market, in different period ( 0 and 30 days) after the treatment. Five kind of medicinal plants (Peumus boldus, Camellia sinensis, Maytenus ilicifolia, Paullinia cupana and Cassia angustifolia), were collected from different cities of São Paulo State, and submitted to irradiation treatment using a ${ }^{60} \mathrm{Co}$ source (type Gammacell 220) with doses of 5,0 kGy and $10 \mathrm{kGy}$ and at dose rate of $3.0 \mathrm{kGy} / \mathrm{h}$. Non-irradiated samples (control group) were used for fungal counts and serial dilutions from $10^{-1}$ to $10^{-6}$ of the samples were seeded in duplicates and plated using the surface culture method in Dichloran $18 \%$ Glycerol Agar (DG 18) and were counted after five days at $25^{\circ} \mathrm{C}$. The control group revealed the presence of genera Aspergillus and Penicillium, which are known as toxigenic fungi and a few samples of control group were within the safety limits of World Health Organization (WHO, 1998) to medicinal plants. In response to resistance of ionizing treatment, in the dose of $5 \mathrm{kGy}$, it was observed that the genera Aspergillus, Phoma and Syncephalastrum were radio-resistant after the process (day 0 and $30^{\circ}$ day). The treatment by gamma radiation was effective in decontamination of all irradiated samples of medicinal plants, after 30 days, with the dose of $10 \mathrm{kGy}$ and kept of veiled conditions. It was not detected aflatoxins in samples of control group, even though these samples were heavily contaminated with Aspergillus flavus.
\end{abstract}




\section{SUMARIO}

1 INTRODUÇÃO

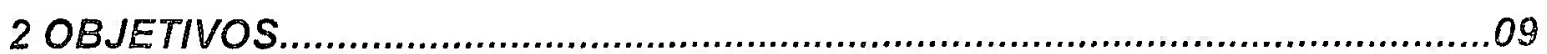

3 REVISÃO DA LITERATURA

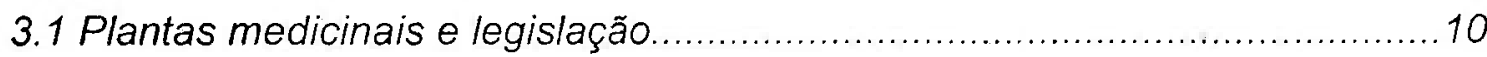

3.2 Contaminação fúngica em produtos de origem vegetal.............................17

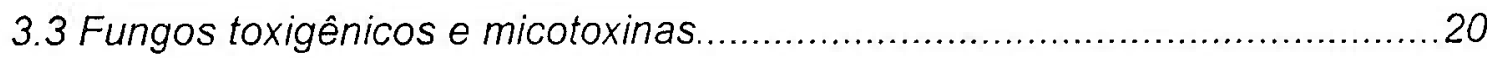

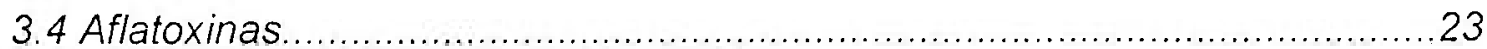

3.5 Efeitos da radiação ionizante em fungos e $\mathrm{em}$ aflatoxinas..........................2.25

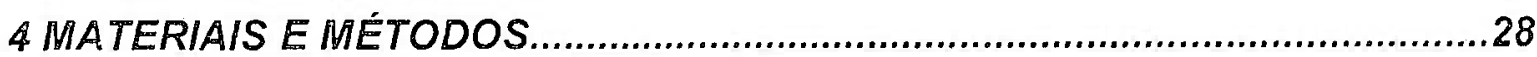

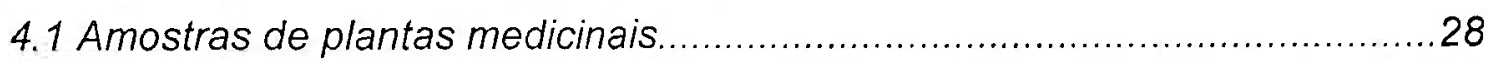

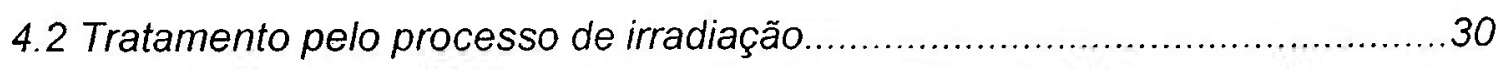

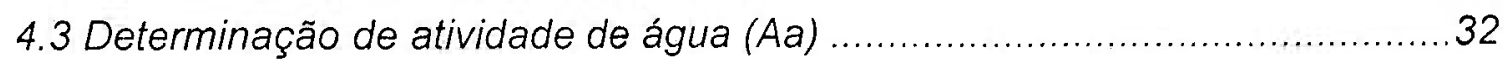

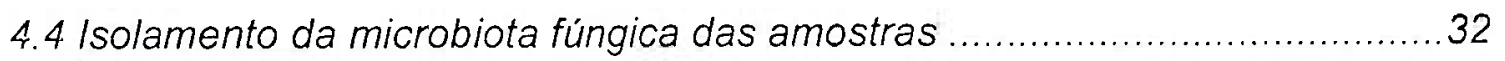

4.5 Potencial toxigênico das cepas de Aspergillus flavus isolados......................34

4.6 Análise da presença de aflatoxinas nas amostras.........................................35

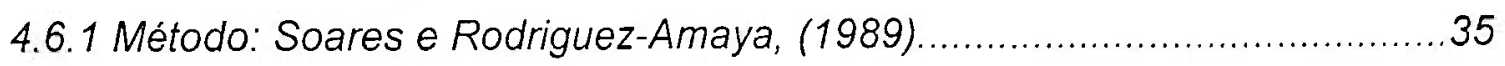

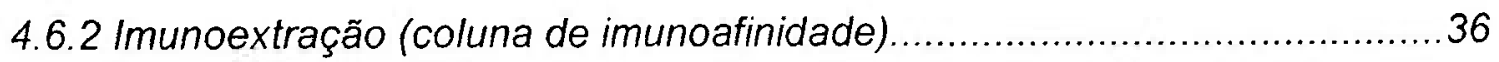

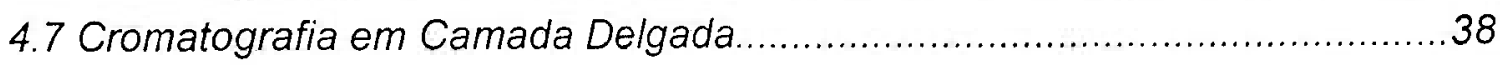

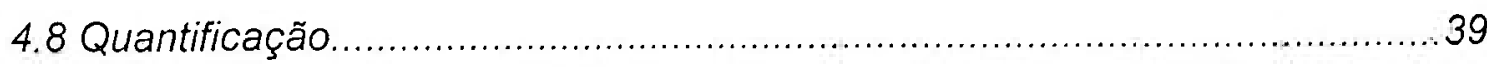

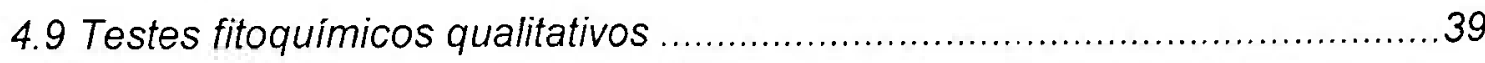

5 DELINEAMENTO EXPERIMENTAL......................................................42

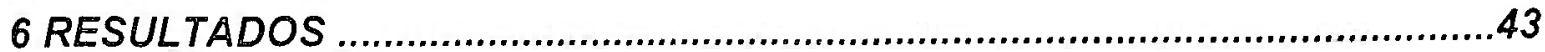

6.1 Determinação da atividade de água $(A a)$............................................43 
6.2 Pesquisa da microbiota füngica do grupo controle ...............................44

6.3 Freqüência (\%) da contaminação fúngica por locais de venda .............50

6.4 Pesquisa da microbiota fúngica (amostras irradiadas). .......................51

6.5 Extração de Aflatoxinas das amostras .............................................65

6.5. Extração de aflatoxinas (Soares e Rodriguez-Amaya, 1989).............6.65

6.5 .2 Imunoextração.................................................................66 66

6.6 Potencial toxigênico das cepas de A. flavus isolados..........................66

6.7 Testes fitoquimicos qualitativos.......................................................66

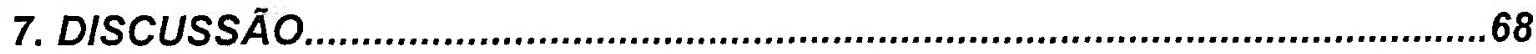

7.1 Determinação da atividade de água $(A a)$........................................68

7. 2 Pesquisa da microbiota fúngica do grupo controle ...............................70

7.3 Freqüência (\%) de isolados fúngicos por locais de venda....................71

7. 4 Pesquisa da microbiota fúngica (amostras irradiadas). .......................72

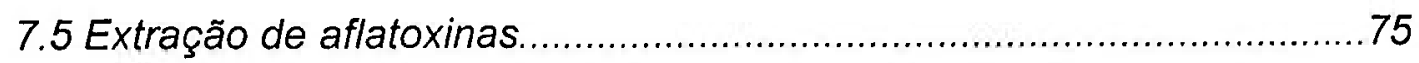

7.5.1 Método: Soares e Rodriguez-Amaya (1989). ................................75

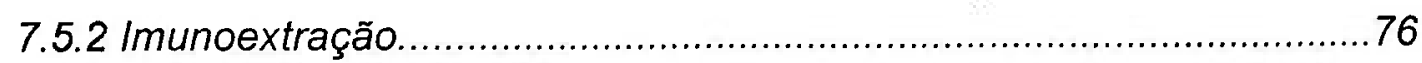

7.6 Potencial toxigênico das cepas de A. flavus isolados..........................78

7.7 Testes fitoquimicos qualitativos................................................ 80

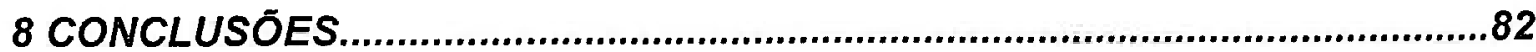

REFERÊNCIAS BIBLIOGRÁFICAS.....................................................84 


\section{LISTA DE TABELAS}

Página

TABELA 1 Designação, emprego e substâncias marcadoras das plantas medicinais Boldo, Sene, Espinheira Santa, Guaraná e Chá verde.

TABELA 2 Atividade de água das amostras controle (C), irradiadas com $5 \mathrm{kGy}(5)$ e irradiadas com $10 \mathrm{kGy}(10)$ de drogas vegetais, adquiridas do mercado atacadista e varejista.

TABELA 3 Contagens de fungos isolados (UFC/g) das amostras do grupo controle (não irradiadas) e irradiadas com a dose de $5 \mathrm{kGy}$ analisadas no dia 0 e após 30 dias de Boldo. .55

TABELA 4 Contagens de fungos isolados (UFC/g) das amostras do grupo controle (não irradiadas) e irradiadas com a dose de $5 \mathrm{kGy}$ analisadas no dia 0 e após 30 dias de Espinheira santa. 56

TABELA 5 Contagens de fungos isolados (UFC/g) das amostras do grupo controle (não irradiadas) e irradiadas com a dose de $5 \mathrm{kGy}$ analisadas no dia 0 e após 30 dias de Sene. 57

TABELA 6 Contagens de fungos isolados (UFC/g) das amostras do grupo controle (não irradiadas) e irradiadas com a dose de $5 \mathrm{kGy}$ analisadas no dia 0 e após 30 dias de Guaraná em pó. 
TABELA 7 Contagens de fungos isolados (UFC/g) das amostras do grupo controle (não irradiadas) e irradiadas com a dose de $5 k G y$ analisadas no dia 0 e após 30 dias de Chá verde.

TABELA 8 Contagens de fungos isolados (UFC/g) das amostras do grupo controle (não irradiadas) e irradiadas com a dose de $10 \mathrm{kGy}$ analisadas no dia 0 e após 30 dias de Boldo. 60

TABELA 9 Contagens de fungos isolados (UFC/g) das amostras do grupo controle (não irradiadas) e irradiadas com a dose de $10 \mathrm{kGy}$ analisadas no dia 0 e após 30 dias de Espinheira santa.

TABELA 10 Contagens de fungos isolados (UFC/g) das amostras do grupo controle (não irradiadas) e irradiadas com a dose de $10 \mathrm{kGy}$ analisadas no dia 0 e após 30 dias de Sene. 62

TABELA 11 Contagens de fungos isolados (UFC/g) das amostras do grupo controle (não irradiadas) e irradiadas com a dose de $10 \mathrm{kGy}$ analisadas no dia 0 e após 30 dias de Guaraná em pó. 63

TABELA 12 Contagens de fungos isolados (UFC/g) das amostras do grupo controle (não irradiadas) e irradiadas com a dose de $10 \mathrm{kGy}$ analisadas no dia 0 e após 30 dias de Chá verde. 


\section{LISTA DE FIGURAS}

Página

FIGURA 1 Estruturas quimicas das principais aflatoxinas.

FIGURA 2 Pontos de venda em feira livre e apresentação à granel em sacarias 28

FIGURA 3. Pontos de venda em feira livre e apresentação à granel em sacarias 28

FIGURA 4 Pontos de venda em feira livre e apresentação à granel em sacarias 28

FIGURA 5 Produtos dispostos em lojas especializadas e embalados. 29

FIGURA 6 Produtos dispostos em lojas especializadas e embalados. .29

FIGURA 7 Produtos dispostos em lojas especializadas e embalados. 29

FIGURA 8 Fracionamento e preparo das amostras coletadas do mercado atacadista para análises em laboratório.

FIGURA 9 Fracionamento e preparo das amostras coletadas do mercado atacadista para análises em laboratório.

FIGURA 10 Fracionamento e preparo das amostras coletadas do mercado atacadista para análises em laboratório.

FIGURA 11 Fracionamento e preparo das amostras coletadas do mercado atacadista para análises em laboratório. 
FIGURA 12 Sene.

FIGURA 13 Guaraná. 30

FIGURA 14 Espinheira santa. 30

FIGURA 15 Chá verde .30

FIGURA 16 Boldo. 30

FIGURA 17 Amostras embaladas para o tratamento pelo processo de irradiação. 31

FIGURA 18 Amostras embaladas para o tratamento pelo processo de irradiação.

FIGURA 19 Fonte Gammacell $-{ }^{60} \mathrm{Co}$ (IPEN - CNEN/SP).

FIGURA 20 Equipamento Aqualab do Laboratório de Micotoxinas (ICB II-USP) utilizado na determinação da Aa.

FIGURA 21 Isolamento da microbiota.

FIGURA 22 Incubação das placas a $25^{\circ} \mathrm{C}$. 33

FIGURA 23 Imagem de microscopia óptica de Aspergillus spp. 33

FIGURA 24 Imagem de microscopia óptica de Penicillium spp. 33 
FIGURA 25 Teste de potencial toxigênico em ágar côco de Aspergillus spp.

FIGURA 26 Teste de potencial toxigênico em ágar côco de Aspergillus spp.

FIGURA 27 Esquema de extração de aflatoxinas (Soares \& Rodriguez-Amaya1989) 36

FIGURA 28 Coluna Aflatest ${ }^{\oplus}$-VICAM. 37

FIGURA 29 Uso da coluna laboratório de Micotoxinas (CB II/USP). 37

FIGURA 30 Imunoextração de aflatoxinas por coluna de imunoafinidade (Bugno, 2006). 38

FIGURA 31 Cromatografia em camada delgada (CCD). 39

FIGURA 32 Rotaevaporador (Instituto Biológico). .40

FIGURA 33 Extratos obtidos após secagem. 40

FIGURA 34 Representação esquemática das etapas do experimento .42

FIGURA 35 Isolados fúngicos em placas de Petri (diluições de $10^{-1}$ a $10^{-5}$ ) .44

FIGURA 36 Freqüência de gêneros de fungos isolados em amostras de Boldo (não irradiadas) 
FIGURA 38 Freqüência de gêneros de fungos isolados em amostras de Espinheira santa (nẫo irradiadas) 46

FIGURA 39 Isolados fúngicos do grupo controle de Espinheira santa. .46

FIGURA 40 Freqüência de espécies de Aspergillus isolados em amostras de Espinheira santa (não irradiadas)...

FIGURA 41 Freqüência de gêneros de fungos isolados em amostras de Sene (não irradiadas).

FIGURA 42 Freqüência de espécies de Aspergillus isolados em amostras de Sene (não irradiadas).

FIGURA 43. Freqüência de gêneros de fungos isolados em Guaraná em pó (não irradiado).

FIGURA 44 Freqüência de espécies de Aspergillus isolados em amostras de Guaraná (não irradiadas).

FIGURA 45 Freqüência de gêneros de fungos isolados em Chá verde (não irradiado).

FIGURA 46 Freqüência de espécies de Aspergillus isolados em amostras de Chá verde (não irradiado)..

FIGURA 47 Comparação da contaminação fúngica de plantas medicinais de acordo com a forma de comercialização..

FIGURA 48 Freqüência de fungos da amostras controles e irradiadas no dia 0 e após 30 dias.. 
FIGURA 49 Phoma spp. em Sene (5 kGy).

FIGURA 50 Aspergillus spp. em Sene (5kGy). 53

FIGURA 51 Colônia de A. niger. 53

FIGURA 52 Colônia de Syncephalastrum spp. 53

FIGURA 53 Syncephalastrum spp. 53

FIGURA 54 Gêneros fúngicos isolados em drogas vegetais, após o tratamento com a dose de $5 \mathrm{kGy}$ (dia 0 ).

FIGURA 55 Gêneros fúngicos isolados em drogas vegetais, após o tratamento com a dose de $5 \mathrm{kGy}\left(30^{\circ} \mathrm{dia}\right)$.

FIGURA 56 Isolados fúngicos em amostras de Sene após 30 dias do tratamento pelo processo de irradiação (controle, 5 e $10 \mathrm{kGy}$ ). 65

FIGURA 57 Cromatografia (EE) de Chá verde (controle, 5 e 10 kGy). 67

FIGURA 58 Cromatografia (EH) de Chá verde (controle, 5 e $10 \mathrm{kGy}$ ) 67

FIGURA 59 Cromatografia (EE) de E. santa (controle, 5 e $10 \mathrm{kGy}$ ) .67

FIGURA 60 Cromatografia (EH) de E. santa (controle, 5 e $10 \mathrm{kGy}$ ) .67

FIGURA 61 Cromatografia (EE) das amostras do grupo controle, $5 \in 10$ kGy.......67

FIGURA 62 Cromatografia (EH) das amostras do grupo controle, 5 e $10 \mathrm{kGy} \ldots \ldots . .67$ 


\section{IVTropucão}

Produtos naturais com propriedades terapêuticas são utilizados desde 0 início da história da civilização humana e, durante muito tempo, foi o principal recurso terapêutico empregado na prevenção, no tratamento, na cura de distúrbios, disfunçōes ou doenças em homens e animais (Choi et al., 2002; Veiga et al., 2005).

O descobrimento das propriedades curativas das plantas ocorreu de forma meramente intuitiva, através da observação de animais, que buscavam rás ervas a cura para suas doenças (Hart, 2005). Estudos arqueológicos demonstraram a existência de antigos papiros egípcios contendo a descrição do uso de plantas, na terapia médica, que se divulgou para a Mesopotâmia, disseminando-se mais tarde entre os gregos e romanos, que herdaram e aperfeiçoaram os conhecimentos egipcios (Mors, 1982). A maioria das plantas medicinais de interesse nos dias atuais, advém de civilizações antigas da África, Ásia, América cio norte, Central e do Sul (Phillipson, 2001).

Recentemente, o foi encontrado junto ao corpo do chamado Iceman (Homem do gelo), descoberto nos Alpes Italianos em 1991, com idade aproximada de 5.300 anos, fragmentos de "fungo de videira" (Birch fungus ou Piptoporus betulinus), presumidamente usado como laxante e antibiótico (Capasso, 1998).

Durante o Renascimento, com a valorização da experimentação e com as grandes viagens para as Índias e América, nasceu um novo período de progresso no conhecimento das plantas e suas aplicações, após um periodo de estagnação na Idade Média. A partir do século XV houve uma preocupação em catalogar um 
grande número de vegetais, identificando-os e classificando-os de acordo com a procedência e características dos principios ativos. A medicina popular e o conhecimento sobre o uso de plantas são os resultados de várias influências primitivas, culturais e históricas (Garcia, 2003; Rates, 2001).

Heinrich et al. (1992) relatam que levantamentos realizados com uma comunidade indígena, demonstraram que o sabor "amargo e adstringente" eram os indicadores na seleção do uso da erva para propósitos de cura e tratamento. Estas observações sugerem que os homens primitivos e animais buscavam as partes de plantas mais amargas, adstringentes ou repugnantes.

De 25 plantas medicinais estudadas, encontradas na natureza, o sabor amargo ou adstringente foi citado em 16 (73\%) destas. O gosto amargo, adstringente ou repugnante, caracterizando a não palatabilidade de uma parte da planta, indica que esta é a região onde a substância química marcadora ou ativa encontra-se presente (Hart, 2005).

A Revolução Industrial e o desenvolvimento da química orgânica provocaram a substituição dos medicamentos vegetais por produtos contendo princípios ativos deles extraidos, ou seus derivados sintéticos, através de modificações estruturais e sintese de novas moléculas. Os produtos naturais passaram a apresentar um significado místico e esta abordagem era oposta ao novo modus vivendi das sociedades industrializadas, que consideravam a utilização de produtos naturais como opção de pessoas incultas e de baixa renda e não aferiam a estes produtos qualquer valor farmacológico (Rates, 2001).

Entretanto, com o passar do tempo, as plantas continuaram sendo importantes no desenvolvimento de novas drogas e cerca de $30 \%$ dos fármacos prescritos são derivados de plantas e dos 252 fármacos considerados básicos ou 
essenciais pela OMS, $11 \%$ são exclusivamente de origem vegetal (Calixto 2000; Calixto 2005; Chan 2003, Rates 2001).

O crescimento da indústria farmacêutica e o desenvolvimento de novos $e$ mais eficazes fármacos sintéticos, não diminuíram a importância das plantas medicinais e, nas últimas décadas, tem sido verificado progressivo aumento na demanda de plantas medicinais em paises como França, Itália, Inglaterra, Espanha e Estados Unidos (Abu-Irmaileh e Afifi, 2003; Bent e Ko, 2004).

Foi neste contexto, observada a tendência generalizada de retorno ao tratamento de doenças com plantas, que a Organização Mundial da Saúde (OMS), em Assembléia Geral em 1978, determinou o início de um prograrra mundial com o fim de avaliar e utilizar os remédios da chamada medicina tradicional. A OMS estima que $80 \%$ da população deste planeta, de algum modo, utiliza plantas medicinais como medicamentos e que 25.000 espécies de plantas sejam usadas nas preparações da medicina tradicional. $\dot{E}$ conveniente lembrar que mais de 365.000 espécies de plantas já foram catalogadas e isto corresponde a cerca de $60 \%$ das plantas existentes (Garcia, 2006).

Por definição, drogas vegetais são plantas medicinais ou suas partes, que após processos de coleta, estabilização e secagem estão em condições de serem utilizadas como medicamentos. As preparações derivadas de droga vegetal são produtos da extração da matéria-prima vegetal, como por exemplo, extratos, tinturas e exsudatos, enquanto que fitoterápicos correspondem a medicamentos obtidos exclusivamente de matérias-primas vegetais, sendo caracterizados pelo conhecimento de sua eficácia e dos riscos de seu uso, assim como pela reprodutibilidade e constância de sua qualidade (Brasil, 2004).

Atualmente, aproximadamente $82 \%$ da população brasileira utiliza produtos à base de ervas. Vários são os fatores econômicos, sociais e culturais que influenciam a utilização de plantas medicinais e terapias alternativas: 
- Elevado custo dos medicamentos convencionais, que torna o acesso proibitivo à parte da população (Fennel et al., 2004; Veiga et al., 2005);

- Insatisfação com a medicina convencional (considerada ineficiente) e busca por terapias alternativas (Abu-Irmaileh e Afifi, 2003, Rates, 2001);

- Freocupação com efeitos adversos de medicamentos convencionais e a crença que medicamentos naturais são mais seguros e saudáveis (AbuIrmaileh e Afifi, 2003, Rates, 2001; Chan, 2003).

A movimentação no mercado de produtos de origem vegetal reflete o crescente interesse e aumento do comércio. Estima-se que, em 1997, o mercado mundial movimentou cerca de US\$ 10 bilhões, com crescimento de $6,5 \%$ ar ano (Calixto 2000; Rates, 2001). Neste mesmo ano, o mercado europeu movimentou cerca de US\$ 7 bilhões, sendo US\$ 3,5 bilhões na Alemanha, US\$1,8 bilhão na França, US\$ 800 milhões na Itália, US $\$ 500$ milhões no Reino Unido, US\$300 milhões na Espanha e cerca de US\$ 100 milhões nos países nórdicos. No Japão e alguns paises da Ásia alcançaram cerca de US\$2,1 bilhões e US\$2,3 bilhões, respectivamente (Calixto 2000; Rates, 2001; Veiga et al., 2005).

No Brasil, até 1996, a estimativa do consumo de medicamentos sintéticos girava em torno de $63 \%$, adquiridos por uma parcela da população de apenas $20 \%$. O restante encontrava nos produtos de origem natural, especialmente as plantas medicinais, a principal ou única fonte de recursos terapêuticos, justificando o crescimento do mercado de medicamentos fitoterápicos, na ordem de $15 \%$ ao ano (Di Stasi 1996).

O Brasil não se destaca na produção de fitoterápicos, quando comparado a países como China, India e Alemanha. O mercado interno movimenta cerca de US\$ 500 milhões, apesar de apresentar a maior biodiversidade do planeta, com 60.000 espécies vegetais que correspondem a $20 \%$ de toda flora mundial. Problemas econômicos, culturais e sociais, falta de planejamento que garanta a 
utilização racional dos recursos naturais e o difícil acesso a informações cientíícas que permitam assegurar a qualidade, eficácia e segurança, são algumas das dificuldades encontradas e que, freqüentemente, resultam em produtos cuja qualidade não atende requisitos minimos (Simões e Schenkel, 2003; Rates, 2001).

O uso individual de fitoterápicos não é considerado como um problema de Saúde Pública. No entanto, o uso de medicamentos naturais passou a ser um problema de Saúde Pública, nos dias atuais, com o advento da produção maciça e o consumo massificado de lotes considerados como "alterados, adulterados ou impróprios para o consumo", onde qualquer problema relacionado à baixa qualidade atinge centenas de pessoas, conforme descrito no artigo 62, da Lei Federal 6.360 (Brasil, 1976).

A maioria das plantas medicinais, comercializadas in natura ou embaladas, apresenta-se fora do padrão, ou seja, o produto não tem assegurado suas propriedades terapêuticas e aromáticas preconizadas e/ou estão contaminados por impurezas, tais como terra, areia, dejetos animais, outras espécies vegetais, coliformes fecais, etc., contradizendo a idéia de que os produtos de origem vegetal sejam freqüentemente considerados seguros por sua origem natural. Esta situação foi gerada pela pouca exigência dos consumidores com relação à qualidade do produto, à ação incipiente da fiscalização oficial e aos produtores que oferecem um produto de baixa qualidade, ocasionando um círculo vicioso, em prejuízo ao público interno fraco e desinformado (Brasil, 2006).

A necessidade de comprovação da qualidade, segurança e eficácia envolvem análises complexas e a falta de especificações farmacopêicas, contribui para a baixa qualidade dos produtos de origem vegetal, além de possibilitar a ocorrência de adulterações. São vários os relatos de produtos de origem vegetal adulterados, incorretamente identificados ou substituídos por espécies diferentes com mesma indicação de uso (Bent e Ko, 2004, Veiga et al., 2005). 
Muitos produtos podem estar contaminados com resíduos de pesticidas, metais tóxicos, como arsênico, chumbo, mercúrio, cádmio e tálio, além de microrganismos e suas toxinas (De Smet, 2004; Tassaneeyakul et al., 2004). Entre as fontes de contaminação, podem ser citados o ambiente, as condições de cultivo e colheita, secagem, processamento, armazenamento e o transporte de plantas medicinais (Chourasia, 1995; Chan, 2003; Smolinske, 2005).

Fatores ambientais podem interferir na qualidade de drogas vegetais e preparações derivadas não apenas por permitirem a decomposição química de seus constituintes, mas também por permitirem a contaminação por microrganismos e, portanto, é esperado que drogas vegetais estejam contaminadas por um amplo espectro de microrganismos. Diversos trabalhos relatam a presença de fungos toxigênicos em especiarias, substratos de plantas medicinais e frutas (Aziz et al., 1997; Abu-Irmaileh e Afifi, 2003; Efuntoye, 1996).

Esporos ou fragmentos de micélio (presentes no solo, em restos de plantas, sementes ou transportados pela chuva e insetos) são os responsáveis pelo início da contaminação e pelo desenvolvimento do fungo na planta, particularmente no que se refere às sementes imaturas (Aziz et al., 2002).

Durante a colheita, as sementes são expostas a danos mecânicos e à contaminação fúngica. Após a colheita, o desenvolvimento dos fungos toxigênicos e a produção de micotoxinas são dependentes de uma complexa série de fatores (Ciegler, 1978):

(1) susceptibilidade do substrato à colonização do fungo toxigênico;

(2) fatores físicos: temperatura do ambiente, umidade do substrato, umidade relativa do ar durante o armazenamento, aeração, danos mecânicos e tempo de armazenamento; 
(3) fatores biológicos: capacidade genética do fungo em produzir micotoxinas, quantidade de esporos viéveis, interação de diferentes fungos existentes no mesmo substrato, inieração de micotoxinas e presença de insetos.

A presença de fungos potencialmente toxigênicos encontrados em drogas vegetais, deve ser considerado um indicativo em potencial para a contaminação por micotoxinas, que podem causar efeitos agudos e crônicos em várias espécies, nos diferentes órgãos e sistemas (Nunes, 2003).

Cerca de 300 toxinas são conhecidas, entretanto, somente algumas têm sido bem estudadas. Para as micotoxicoses humanas, as aflatoxinas e ocratoxinas são apontadas como carcinogénicas, e as iusariotoxinas (tricotecenos e fumonisinas) são de considerável importância, podendo causar riscos à saúde humana e animal (Yoshisawa, 1999; Nunes, 2003).

Efuntoye (1999) avaliou a relação entre tempo de estocagem das plantas (por um periodo de três meses) e niveis toxigênicos, demonstrando que, quanto maior o tempo de armazenamento, maior era a produção de toxinas. $O$ mesmo autor ainda observou que, apús 90 dias de estocagem, os níveis toxigênicos apresentaram elevação máxima nas plantas.

Nunes (2003) demonstrou altos niveis de aflatoxinas em 50 amostras de cinco tipos de fitoterápicos de uso comum na cidade de São Paulo. Neste estudo foi constatado que $80 \%$ das amostras analisadas apresentaram elevados índices de contaminação, tornando o produto impróprio para o consumo, sendo que $56 \%$ dos isolados de Aspergillus flavus e os dois isolados de Aspergillus parasiticus produziram aflatoxinas.

Roy et al. (1988) demonstraram a presença de aflatoxinas em 14 de 15 amostras de plantas medicinais, estudadas na India, sendo encontradas as 
seguintes espécies fúngicas: Aspergillus flavus, A. candidus, A. niger, A luchusnsis, A. ochraceus, A. nidulans, Fusarium verticillioides, F. oxysporum, Curvularia lunata, Penicillium citrinum, Alternata alternaria e Rhizopus stolonifer.

O emprego do tratamento pelo processo de irradiação pode ser um valioso meio de prevenir os riscos de contaminação fúngica, além de representar a alternativa mais adequada para a descontaminação desta classe de produtos. Aziz et al. (1997), estudaram os efeitos da radiação gama na viabilidade de fungos e actinomicetos contaminantes de plantas medicinais, revelando que $5 \mathrm{kGy}$ foi a dose letal para a maioria dos fungos e actinomicetos contaminantes. Sweiha (1984) e Moussa (1988) relataram que actinomicetos são inteiramente eliminados após o iratamento com a dose de $10 \mathrm{kGy}$.

Os custos líquidos da irradiação oscilam entre 10 e 15 dólares americanos por tonelada, no caso da aplicação de uma dose baixa (por exemplo, para inibir germinações nas batatas e nas cebolas) e, entre 100 e 250 dólares por tonelada, no caso de aplicação de uma dose alta (por exemplo, para garantir a qualidade higiênica das especiarias). Em alguns casos, a irradiação pode ser muito menos custosa ou, como na maioria dos casos, o preço final do produto não aumenta somente pelo fato de que um produto tenha sido tratado pelo processo de radiação ionizante (ICGFI, 1999). 


\section{OBJETIVOS}

O presente estudo propôs um levantamento da contaminação fúngica de plantas medicinais, em cinco municípios, onde há predominância da classe mais baixa da população e o comércio de plantas medicinais é intenso. Com base nessas considerações, os principais objetivos foram:

- Apresentar um panorama local do mercado de plantas medicinais e características dos produtos comercializados quanto à contaminação fúngica;

- Isolar e identificar os principais gêneros fúngicos em cinco amostras de drogas vegetais coletadas do comércio varejista e atacadista de quatro municipios pertencentes à Direção Regional de Saúde (DIR IV-Franco da Rocha) e do município de São Paulo;

- Identificar as principais espécies e analisar o potencial toxigênico do gênero Aspergillus, bem como determinar a presença de aflatoxinas nas amostras de plantas medicinais coletadas;

- Verificar os efeitos da radiação ionizante (raios gama), nas doses de 5 e $10 \mathrm{kGy}$ na descontaminação das drogas vegetais logo após o tratamento (dia 0) e após 30 dias;

- Analisar o perfil fitoquímico das drogas vegetais, após o tratamento pelo processo de radiação ionizante, com as doses de 5 e $10 \mathrm{kGy}$. 


\section{REVISÃO DA LITERATURA}

\subsection{Plantas medicinais e legislação}

Fitoquimicos são substâncias produzidas naturalmente pelas plantas, para protegê-las contra vírus, bactérias e fungos. Eles parecem ajudar na prevenção de alguns tipos de doenças e incluem centenas de substâncias como carotenóides, flavonóides, isoflavonas, compostos fenólicos, licopeno, saponinas, terpenos, sulfetos alílicos, indol e várias outras (Simões et al., 2003).

Os fitoquímicos podem ser facilmente encontradús nús alimentos que fazem parte da nossa alimentação habitual: frutas, vegetais, grãos, legumes e sementes. Por meio de plantas medicinais secas ou frescas e seus extratos naturais, a fitoterapia trata das várias enfermidades. Chamamos de plantas medicinais as que têm aplicação consagrada pelo uso médico ou pelo povo, que constam da Farmacopéia Brasileira ou do The Merk index (Panizza, 1997).

A importância do emprego da matéria-prima vegetal, na obtenção de um fitoterápico, representa um fator importante na produção de um medicamento com qualidade. As matérias-primas ativas de origem vegetal (planta fresca, seca, inteira ou em partes), devido à sua complexidade de composição, requerem cuidados especiais, tanto no armazenamento quanto durante a sua transformação. $\mathrm{Na}$ produção de produtos fitoterápicos, grande atenção deve ser dada ao planejamento da preservação da qualidade físico-química e microbiológica, quer na matériaprima ativa, quer dos produtos intermediário e final (Sonaglio et al., 2003).

Nos anos 80 e 90, em função do aumento do consurno de plantas medicinais decorrente do modismo naturalista existente à época, começaram a surgir regulamentações setoriais complementares para e exploração e comercialização de plantas medicinais (Teixeira, 1985). 
A legislação, sobre medicamentos de origem vegetal, recebe diferentes abordegens em sua regulação no mundo. Na Europa e Ccréia os produtores são obrigadios a apresentarem provas cientificas da segurança e eficácia de cada produto (De Smet, 2004). Nos Estados Unidos, são classificados como suplementos alimentares e não é permitido afirmações quanto a propriedades farmacêuticas, mas são requeridas a certificação e o controle de qualidade destes produtos. A regulação e fiscalização são mais precárias nos paises ern desenvolvimento, onde há grande número de produtos utilizados com base na tradição e no conhecimento empírico sobre seu uso (Sardesai, 2002, Fennel et al., 2004).

No Brasil, os primeiros atos normativos de expressão referentes às plantas medicinais, estavam relacionados com as atividades ligadas à saúde, baseados nos regimentos portugueses que citavam os cuidados com preparações de medicamentos. Essas regulamentações perduraram até a chegada da Família Real portuguesa no Brasil, mas tal fato pouco contribuiu para a normatização dos produtos fitoquimicos, mesmo no período de independência (Marques e Petrovick, 2003).

Os mesmos autores relatam que a publicação da primeira Farmacopéia Brasileira elaborada (praticamente sozinho ao longo de 12 anos de pesquisa) por Rodolfo Albino, contemplou mais de duzentas e oitenta espécies botânicas nacionais e estrangeiras, compondo as monografias a serem usadas como referência nos aspectos de controle da qualidade na produção de medicamentos, Com a expansão das boticas e regulamentação da profissão farmacêutica a partir de 1931, outros Decretos seriam posteriormente publicados para a regulamentação e fiscalização das atividades relacionadas às drogas vegetais.

Atualmente, a fiscalização dos medicamentos fitoterápicos, no Brasil, é realizada pela Anvisa (Agência Nacional de Vigilância Sanitária). O Ministério da 
Saúde, em dezembro de 2000, realizou o Fórum Nacional para a Discussẽo da Proposla de Politica Nacional de Plantas Medicinais e Medicamentos Fitóerápicos. Segundo dados da Anvisa, alguns fitoterápicos podem auxiliar nas patologias mais diversas, como no tratamento de problemas digestivos e biliares. Contudo, aleria para que os pacientes tenham acompanhamento médico, para que não sejam prejudicados com as restrições de uso dos medicamentos (Conselho Regional de Farmácia, 2006). A Resolução - RE n. ${ }^{\circ} 88$, publicada em 16 de março de 2004, relaciona alguns tipos de fitoterápicos com suas propriedades benéficas para a saúde e suas doses recomendadas para uso como por exemplo, a Espinheira santa, Guaraná, Boldo e Sene, onde constam orientações como venda sem prescrição médica e sem restrições de uso para tais drogas vegetais (TAB. 1) (Brasii, 2004).

Boldo-do-Chile (Peumus boldus), Espinheira santa (Maytenus ilicifolia), Guaraná (Paullinia cupana), Sene (Cassia angustifolia) e Chá verde (Camellia sinensis) são algumas das drogas vegetais de maior procura no comércio de produtos naturais e considerando a forma caseira de consumo de drogas vegetais, (como infusões de folhas desidratadas), é importante ressaltar os limites de contaminação microbiológica de tais produtos. Comparando-se com os limites preconizados pela Portaria $n^{\circ} 451$ (revogada pela RDC $n .^{\circ} 12$ ) que determinava os padrões microbiológicos para alimentos e produtos de infusão como chá, café, mate, etc., os valores considerados aceitáveis para bolores e leveduras eram de até $5 \times 10^{3}$ UFC/ g (Brasil, 1997; Brasil, 2001).

A Portaria $\mathrm{n}^{\circ} 123$ de 19 de outubro de 1994, da Secretaria de Vigilância Sanitária do Ministério da Saúde (Brasil, 1994), estabelecia o limite para bolores e leveduras de $1,0 \times 10^{4} \mathrm{UFC} / \mathrm{g}$ em drogas vegetais e determinava a ausência de fungos do gênero Aspergillus, dentre outros microrganismos e seus contaminantes. No entanto, tais especificações não se mantiveram na legislação, uma vez que a 
Portaria $n^{\circ} 123$ foi revogada pela Resolução - RDC $n^{\circ}$. 17, publicada em 24 de fevereiro de 2000 pela ANVISA.

TABELA 1. Designação, emprego e substâncias marcadoras das plaritas medicinais Boldo, Sene, Espinheira Santa, Guaraná e Chá Verde.

\begin{tabular}{|c|c|c|c|}
\hline Nome da planta & $\begin{array}{l}\text { Principios ativos ou } \\
\text { marcadores }\end{array}$ & $\begin{array}{l}\text { Parte da } \\
\text { planta }\end{array}$ & Emprego \\
\hline $\begin{array}{l}\text { Boldo-do-Chile } \\
\text { (Peumus boldus) }\end{array}$ & $\begin{array}{l}\text { Oleo essencial (eucaliptol, } \\
\text { ascaridol, cineol, eugenol e } \\
\text { alfa pineno); alcalóides } \\
\text { (boldina); taninos; } \\
\text { glicosídeos; flavonóides }\end{array}$ & Folhas & $\begin{array}{l}\text { Colecistites; eliminador } \\
\text { de cálculo biliar; } \\
\text { afecções gástricas, } \\
\text { hepáticas e renais; } \\
\text { insuficiência hepática. }\end{array}$ \\
\hline $\begin{array}{l}\text { Espinheira santa } \\
\text { (Maytentis ilicifolia) }\end{array}$ & $\begin{array}{c}\text { Carotenóides; taninos; óleo } \\
\text { essencial; terpenos } \\
\text { (maitensina, maitomprina, } \\
\text { maitombutina e maitolidina); } \\
\text { flavonóides; pigmentos } \\
\text { antocianina; mucilagens; } \\
\text { açúcares. }\end{array}$ & Folhas & $\begin{array}{l}\text { Afecções gástricas, } \\
\text { úiceias, feiidas, } \\
\text { escaias, afecções da } \\
\text { pele, fermentações } \\
\text { intestinais. }\end{array}$ \\
\hline $\begin{array}{c}\text { Guaraná (Paullinia } \\
\text { cupana) }\end{array}$ & $\begin{array}{l}\text { Cafeina; óleo fixo; } \\
\text { pigmentos (matéria-prima } \\
\text { corante formada de } 2 \\
\text { substâncias, uma vermelha } \\
\text { e outra parda); saponinas; } \\
\text { amidos; pectinas; fibras; } \\
\text { sais minerais; taninos. }\end{array}$ & Semente & $\begin{array}{c}\text { Diarréias crônicas; } \\
\text { disenterias; enxaquecas; } \\
\text { hemicranias; máscara } \\
\text { facial para pele oleosa; } \\
\text { astenia; estimulante do } \\
\text { SNC. }\end{array}$ \\
\hline $\begin{array}{l}\text { Sene (Cassia } \\
\text { angustifolia) }\end{array}$ & $\begin{array}{c}\text { Derivados } \\
\text { hidroxiantracênicos } \\
\text { (calculados como } \\
\text { senosídeo B) }\end{array}$ & $\begin{array}{l}\text { Folhas e } \\
\text { frutos }\end{array}$ & $\begin{array}{c}\text { Laxativo Suave; } \\
\text { Indicada na constipação } \\
\text { por inércia intestinal }\end{array}$ \\
\hline $\begin{array}{c}\text { Chá verde (Camellia } \\
\text { sinensis) }\end{array}$ & $\begin{array}{c}\text { Catequinas, epicatequina } \\
\text { (EC), epicatequina galato } \\
\text { (ECG), epigalocatequina } \\
\text { (EGC) e epigalocatequina } \\
\text { galato (EGCG). }\end{array}$ & Folhas & $\begin{array}{c}\text { Ação antioxidante; } \\
\text { diminuição dos niveis de } \\
\text { colesterol total, pressão } \\
\text { arterial; propriedades } \\
\text { ligadas ao } \\
\text { emagrecimenio }\end{array}$ \\
\hline
\end{tabular}


A RDC $n^{\circ}$. 17, foi que definiu o regulamento dos medicamentos de origem vegetal e fitoterápicos. Essa resolução enquadrava os produtos em três classes: novos, tradicionais e isentos de registro, em virtude da necessidade de uma politica que coordenasse os produtos de origem natural que, até então, estavam à venda no mercado em categorias indefinidas.

Após a instauração da RDC $n^{\circ}$. 17, foram constatadas algumas falhas em relação à identificação dos produtos fitoterápicos de origem nacional, principalmente em relação ao registro na categoria dos tradicionais.

Posteriormente, a Resolução - RDC nº 48 publicada em 16 de março de 2004, revogou a RDC $\mathrm{n}^{\circ}$. 17 e definiu fitoterápico como "medicamento obtido empregando-se exclusivamente matérias-primas ativas vegetais". É caracierizado pelo conhecimento da eficácia e dos riscos de seu uso, assim como pela reprodutibilidade e constância de sua qualidade. Sua eficácia e segurança são validadas através de levantamentos etnofarmacológicos de utilização, documentações tecno-científicas em publicações ou ensaios clínicos. Não se considera medicamento fitoterápico aquele que, na sua composição, inclua substâncias ativas isoladas, de qualquer origem, nem as associações destas com extratos vegetais". Ainda definiu matéria prima vegetal como "planta medicinal fresca, droga vegetal ou derivada de droga vegetal".

Para registro de um fitoterápico, a RDC n. ${ }^{\circ} 48$ exige a documentação do controle de qualidade do produto acabado, bem como os registros dos testes de pureza e integridade, incluindo: cinzas, cinzas insolúveis em ácido clorídrico, umidade, pesquisa de matérias estranhas, pesquisa de contaminantes microbiológicos e de metais tóxicos. Em caso de utilização de métodos para eliminação de contaminantes, deve-se descrever o método e a pesquisa de eventuais alterações da matéria-prima. 
De acordo com a legislação referente a esta classe de produtos, todas as empresas que solicitam o registro de um fitoterápico, devem apresentar literatura cientifica sobre aspectos relacionados à segurança e eficácia de sua utilização e, apenas são aceitos estudos publicados em revistas e compêndios internacionais reconhecidos pela Agencia Nacional de Vigilância Sanitária (Brasil, 2004). A qualidade implica controle e nele estão envolvidos experimentos nos quais se insere o controle de microrganismos, entre os quais se encontram os fungos filamentosos (Brandão, 1998; Bugno, 2002; Santos, 1995).

Na RDC $n^{\circ} 48$ os limites para contaminação fúngica de drogas vegetais não foram mantidos e, apenas estabelece que o controle da qualidade de drogas vegetais e fitoterápicos devem estar de acordo com a referência bibliográfica da Farmacopéia consultada e reconhecida pela ANVISA.

Embora a prática da fitoterapia encontre uma série de dificuldades, 0 Ministério da Saúde publicou a Portaria $n^{\circ}$ 971, de 3 de maio de 2006, que estabelece a Política Nacional de Práticas Integrativas e Complementares, visando oferecer ao Sistema Único de Saúde - SUS, a possibilidade de tratamento com plantas medicinais e fitoterápicos (Brasil, 2006).

Em 1998 a Worid Health Organization (WHO) publicou o documento Quality control methods for medicinal plant materials, onde são descritos protocolos de metodologias para o controle da qualidade de plantas medicinais. Neste documento consta a determinação de limites de microrganismos patogênicos, incluindo-se fungos toxigênicos, bem como para as aflatoxinas. Os limites para fungos em diferentes substratos de plantas são WHO (1998):

- Limite para contaminação de plantas em estado natural, colhidas sob condições aceitáveis de higiene e onde se pretende aplicar tratamentos adicionais (incluindo descontaminação adicional por processos químicos ou 
físicos): Fungos filamentosos, máximo de $10^{5}$ unidades formadoras de colônias por grama (UFC/g);

- Para matérias-primas de plantas pré-tratadas, antes do consumo, (com água fervente em chás ou infusões) ou que são usadas em formas tópicas: Leveduras e bolores máximo $10^{4} \mathrm{UFC} / \mathrm{g}$;

- Para outras matérias-primas de uso interno: Leveduras e bolores máximo $10^{3} \mathrm{UFC} / \mathrm{g}$.

A Farmacopéia Britânica (2004) e a Farmacopáia Europ̣éia (2000), no anexo intitulado Microbial Quality of Pharmaceutical Preparations, apresenta as seguintes recomendações minimas (sem status mandatório) para produtos contendo uma ou mais drogas vegetais:

- Produtos a que serão adicionados água fervente antes de seu consumo: máximo de $10^{5} \mathrm{UFC} / g$ de bolores e leveduras;

- Para os demais produtos: máximo de $10^{4} \mathrm{UFC} / \mathrm{g}$ de bolores e leveduras.

A Farmacopéia Brasileira (1998) e seus fascículos publicados de 1996 a 2005, apresentam um total de 42 monografias de drogas vegetais e não determina especificações microbiológicas para drogas vegetais, mas indica o limite para produtos de uso oral de $10^{2} \mathrm{UFC} / g$ de bolores e leveduras. A $28^{\mathrm{a}}$ edição da farmacopéia Americana (USP, 2005) recomenda o limite de $10^{3} \mathrm{UFC} / \mathrm{g}$ como especificações mínimas de bolores e leveduras para drogas vegetais (Bugno, 2006). 
Não existe, até o presente momento, uma regulamentação especifica para limites de aflatoxinas em fitoterápicos no Brasil. Para aflatoxinas, a WHO determina testes para a possivel presença de aflatoxinas $B_{1}, B_{2}, G_{1}$ e $G_{2}$, cuja presença de cada uma delas, em qualquer matéria-prima originária de plantas medicinais, é considerada como altamente perigosa. A interpretação dos resultados considerados satisfatórios para pesquisas de aflatoxinas ocorre quando nenhuma mancha é obtida das amostras, correspondente à posição da mancha padrão de aflatoxina, após a cromatografia. Caso apareça uma mancha correspondente à posição da marca do padrão, a amostra deverá ser considerada positiva para a presença da micotoxina e ser posteriormente quantificada.

\subsection{Contaminação fúngica em produtos de origem vegetal}

A obtenção de produtos fitoterápicos, quer seja em escala oficinal, hospitalar ou industrial, requer a produção de acordo com os conceitos atuais de qualidade $e$ as matérias-primas ativas de origem vegetal, requerem cuidados especiais, tanto no armazenamento quanto na sua transformação.

Nas últimas décadas, poucos estudos foram publicados sobre a contaminação fúngica em plantas medicinais. Lutomsky e Kedzia (1980) analisaram 246 amostras de drogas vegetais e verificaram contagens superiores a $10^{2}$ UFC/g de bolores e leveduras em $90 \%$ das amostras e 50 amostras apresentaram os gêneros Aspergillus e Penicillium.

Roy et al. (1988) verificaram a presença de 13 espécies fúngicas, como $A$. flavus, A. candidus, A. niger, A. niger, A. luchuensis, A. ochraceus, A. niciulans, Fusarium verticillioides (moniliforme) e Penicillium citrinum, as quais eram as mais freqüentes. Em 124 amostras de condimentos e ervas advindos de mercados espanhóis, Garrido e colaboradores constataram que $87,5 \%$ apresentaram 
contagens acima de $10^{2} \mathrm{UFC} / g$, com a presença dominante dos gêneros Aspergillus e Penicillium.

Fischer et al. (1993), relataram que 84 amostras de especialidades fitoterápicas, obtidas no comércio de São Paulo, apresentaram contaģens superiores a $10^{2}$ UFC (de bolores e leveduras) por grama de amostra. Chourasia (1995) verificou a presença, principalmente de Aspergillus spp. (A. flavus, $A$. parasiticus e $A$. ochraceus) e Fusarium spp., em $54 \%$ de amostras de drogas vegetais de Bhagapur, Índia.

Santos et al. (i995) analisaram $5 i$ amostras de produtos nitoterajplcos e verificaram que $21,6 \%$ das amostras estavam contaminadas com bolores e leveduras com contagens superiores a $10^{2} \mathrm{UFC} / \mathrm{g}$, com a presença de Aspergillus spp. e Penicillium spp., em 23,5\% e 2,0\%, respectivamente, nas amostras. Efuntoye (1996) isolou 28 espécies de fungos em $25 \%$ das amostras de plantas medicinais adquiridas em Ibadan (Nigéria), cujas espécies dominantes foram $A$. niger, A. flavus, F.verticillioides (moniliforme) e P. expansum.

Alexander et al. (1997) constataram que, em 25 especialidades fitoterápicas constituídas de 250 amostras de comprimidos, 46 amostras em pós e grânulos, 58 amostras de líquido oral e 71 amostras de produtos para uso tópico, 6,4\% apresentaram contagens superiores a $2 \times 10^{2} \mathrm{UFC} / \mathrm{g}$ e em $20 \%$ das amostras de pós ou grânulos, a contaminação era superior a $10^{4} \mathrm{UFC} / \mathrm{g}$. Aziz et al. (1998) verificaram a presença de 10 gêneros fúngicos em 84 amostras de plantas medicinais, coletadas no Cairo (Egito) sendo detectados com maior freqüência $A$. flavus, A. parasiticus, A. niger, Fusarium oxysporum e Fenicillium viriciicatum. 
Halt (1998) analisou 62 amostras de drogas vegetais e 11 amostras de chás com contagens fúngicas variando entre $10^{2}$ e $10^{5}$ e entre $10^{2}$ e $10^{4} \mathrm{UFC} / \mathrm{g}$, respectivamente. $O$ autor isolou os gêneros predominanies como Aspergillic e Penicillium. Abou-Arab et al. (1999) analisaram amostras de drogas vegetais e verificaram que os gêneros Aspergillus e Penicillium foram os mais isolados, também observados por Elshafie et al. (1999) em 48 amostras de chá preto (Camellia sinensis L.) onde a freqüência dominante observada foi de $A$. niger, $A$. flavus e Penicillium spp.

Nos últimos anos, o interesse pelo estudo da contaminação fúngica em plantas medicinais cresceu em relação às décadas anteriores. Estudos mais recerites demonstraiam que a contaminação de bolores ainda permanece elevada. Em 138 amostras de drogas vegetais, adquiridas no comércio da Áustria e Alemanha, Czech et al. (2001) verificaram que $80 \%$ apresentaram contaminação fúngica acima de $10^{2} \mathrm{UFC} / \mathrm{g}$ (com contagens variando entre $10^{1}$ e $10^{6} \mathrm{UFC} / \mathrm{g}$ ). Martins et al. (2001) avaliaram 62 amostras de 7 tipos de plantas medicinais, adquiridas em Lisboa (Portugal) e verificaram populações médias de fungos da ordem de $10^{5} \mathrm{UFC} / \mathrm{g}$.

Martins et al. (2001) avaliaram 62 amostras de plantas medicinais, adquiridas em Lisboa (Portugal) e verificaram a presença de Fusarium spp. $(59,7 \%)$, Aspergillus flavus (22,6\%), A. glaucus (32,2\%) e A. niger (46,8\%), além de Penicillium spp. (61,3\%). Rizzo et al. (2004) isolaram A. flavus e A. parasiticus em $52 \%$ de 152 amostras de plantas medicinais na Argentina, enquanto $16 \%$ apresentaram contaminação com $F$. verticilioides e $F$. proliferatum.

Rocha et al. (2004) analisaram 40 amostras de Sene e Boldo, coletados em farmácias de manipulação e em mercados da cidade de Campinas e constataram que $45 \%$ acima dos limites permitidos pela OMS. Zaroni et al. (2004) verificaram 
que $79 \%$ das 72 amostras de plantas medicinais, produzidas no Estado do Paraná, não atenderam aos parâmetros estabelecidos pela WHO, com contagens que variaram entre $1,0 \times 10^{2}$ e $8,4 \times 10^{6} \mathrm{UFC} / \mathrm{g}$ de bolores e leveduras. Soriani et al. (2005) encontraram valores elevados de fungos em amostras não irradiadas de Ginkgo biloba e guaraná e a contagem total de fungos foi de $10^{3}$ and $10^{5} \mathrm{CFU} / \mathrm{g}$, respectivamente. Entretanto, neste estudo não é discriminado os gêneros de fungos presentes nas drogas vegetais.

Os diversos autores citados relatam ainda a presença de outros gêneros de fungos em plantas medicinais, tais como: Mucor, Rhizopus, Thamnidium, Alternaria, Cunularia, Cladosporium, Paecilomyces, Pullularia, Sporendonema, Syncephalastrum, Tricothecium, Erotium, Absidia, Trichoderma e Rhizoctonia.

\subsection{Fungos toxigênicos e micotoxinas}

A palavra micotoxina é derivada dos termos gregos "mykes", que significa fungo, e "toxikon", que significa toxina ou veneno. O termo micotoxina descreve um grupo bastante diversificado de componentes quimicos, com diferentes fórmulas estruturais, propriedades químicas, físicas e toxicológicas, tendo em comum somente o fato de serem produtos de biossíntese fúngica. Micotoxinas são, desta forma, metabólitos fúngicos capazes de produzir efeitos agudos ou crônicos nos homens e nos animais (Council for Agricultural Science and Technology, 2003).

Micotoxinas são metabólitos secundários orgânicos, de baixo peso molecular, não proteináceos, complexos, com elevada toxicidade, quando em pequenas quantidades, a microrganismos, plantas e animais. Podem ser voláteis, parcialmente voláteis ou não voláteis. As micotoxinas auxiliam os fungos a serem mais competitivos dentro de seu nicho ecológico, mas não são necessárias para o crescimento e desenvolvimento de todas as espécies fúngicas (Bugno, 2006). 
Fungos toxigênicos são aqueles capazes de produzir micotoxinas e são relativamente ubiquos e adaptados para colonizar, crescer e produzir toxinas em uma variedade de substraı̀os, quando em condições favoráveis, de acordo com as exigências das diferentes espécies (Stoloff, 1979). Os principais gêneros fúngicos associados com a produção de micotoxinas são Aspergillus, Fenicillium e Fusarium e são amplamente distribuidos no ecossistema brasileiro (Corrêa, 2000).

O risco potencial da presença de fungos toxigênicos em plantas medicinais é a formação de micotoxinas, principalmente em paises tropicais e subtropicais, que oferecem condições ambientais favoráveis ao crescimento fúngico e à produção de micotoxinas, cuja presença significa um perigo à saúde humana (Bugno et al., 2006).

Em condições específicas, em geral independentes daquelas necessárias ao crescimento fúngico, a contaminação se inicia no campo e continua durante a coleta, secagem e armazenamento (Bennet e Klich, 2003; Stoloff, 1979). O gênero Aspergillus é amplamente distribuido, embora ocorra com maior freqüencia em regiões subtropicais e tropicais; sua capacidade de crescer em condiçőes de alta temperatura e baixa atividade de água permite a colonização em extensa variedade de substratos, sendo encontrado comumente no periodo de armazenamento (Chourasia e Roy, 1991; Pitt et al., 2000).

Os fungos do gênero Penicillium crescem e produzem micotoxinas preferencialmente em climas temperados, como citrinina, ocratoxinas, ácido ciclopiazônico e sterigmatocistina e também estão associados aos periodos de estocagem de matéria-prima. O gênero Fusarium possui espécies adaptadas a vários habitats e são amplamente distribuidos, produtores de várias micctoxinas como tricotecenos, fumonisinas e zearalenona (Pitt et al., 2000). 
Nem todos os fungos são produtores de micotoxinas e a presenç̧a de espécies fúngicas contaminantes não implica na presença de micotoxinâs, que dependem de condições favoráveis à produção e de fatores intrínsecos, como cepas de uma mesma espécie toxigênica, que não possuem capacidade de sintese de micotoxinas, necessitando da avaliação de seu potencial toxigênico quando isoladas (Chourasia, 1995; Corrêa et al., 1997; Norred, 2000).

A principal via de exposição é a ingestão de produtos contaminados, embora a exposição dérmica e inalatória sejam importantes vias a serem consideradas, principalmente em exposições ocupacionais. Os gêneros fúngicos Penicillium e Aspergillus, considerados os principais contaminantes de alimentos, säo encontrados em áreas úmidas de edificações e a exposição crônica às suas micotoxinas tem sido estudada em ambientes internos. Estudos em animais indicaram que a exposição inalatória pode ser mais tóxica do que a ingestão. $A$ ausência de fungos toxigênicos no ambiente não é um indicativo de que não existam micotoxinas, uma vez que estas podem persistir no ambiente, mesmo que o fungo produtor já não esteja presente no local (Jarvis e Miller, 2005).

A severidade da micotoxicose é dependente do tipo de micotoxina envolvida, sinergismo com outras substâncias químicas ou micotoxinas, duração e via de exposição, dose, idade, sexo, predisposição genética, estado nutricional e de saúde do indivíduo. Os efeitos podem ser agudos ou crônicos, carcinogênicos, mutagênicos, teratogênicos e/ou imunossupressores (Bugno, 2006; Bennet e Klich, 2003).

A incidência ocorre, em geral, em partes do mundo onde a manipulação e armazenamento de produtos são realizados sob condições precárias, nas quais existem problemas de má nutrição e pouca regulação para proteger as populações expostas. Poucos são os estudos referentes à incidência de micotoxinas em drogas vegetais e fitoterápicos (Bugno, 2006). 


\subsection{Allatoxinas}

Os fungos comumente encontrados em drogas vegetais são responsáveis pela deíerioração de plantas medicinais e, algumas delas que contêm óieos essenciais, podem sofrer rancidez biológica, ou seja, um tipo de deterioração causada por enzimas hidroliticas e contaminantes microbiológicos, no caso mais conhecido, as aflatoxinas, que possuem propriedades carcinogênicas e são produzidas pelos fungos toxigênicos Aspergillus flavus, A. parasiticus e $A$. nomius (Simões et al., 2003; IARC, 1993; Pitt \& Hocking, 1999).

As aflatoxinas são metabólitos secundários altamente tóxicos produzidos por espécies do gênero Aspergillus, principalmente A. flavus Link, A. parasiticus Speare e A. nomius. Quimicamente, as aflatoxinas são cumarinas substituidas ligadas a deidrofurano. São conhecidas 17 substâncias do grupo, entretanto, as mais importantes em alimentos são as aflatoxinas $B_{1}, B_{2}, G_{1}$ e $G_{2}$ (FIG. 1). A aflatoxina $B_{1}$ é a mais tóxica seguida da $G_{1}, B_{2}$ e $G_{2}$ (Wyllie \& Morehouse, 1977).

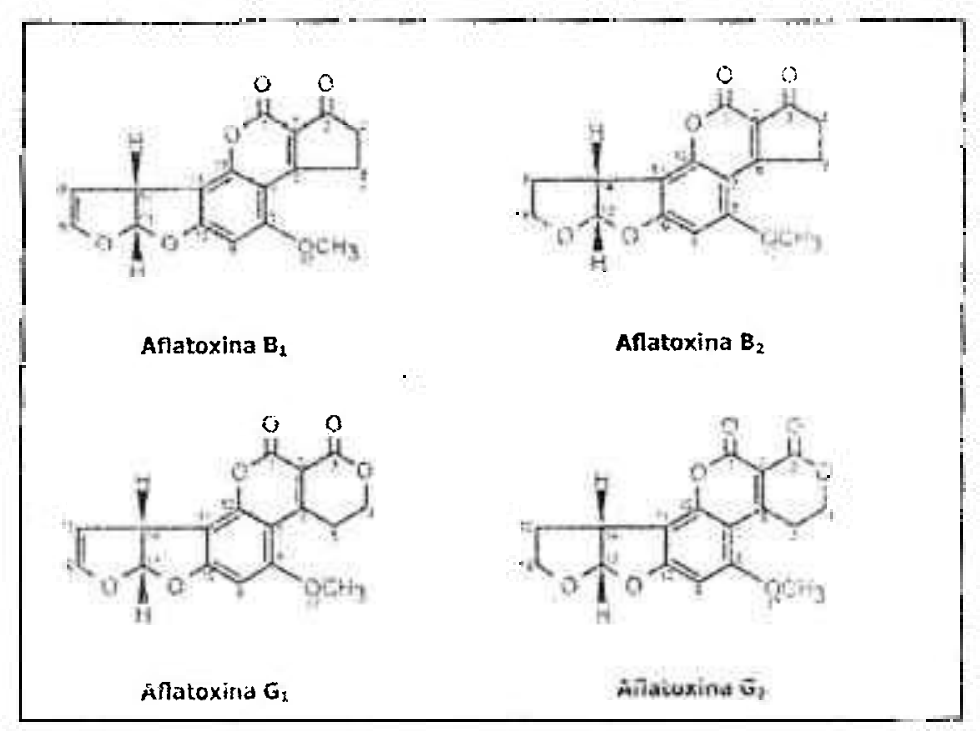

FIGURA 1. Estruturas quimicas das principais aflatoxinas (Fonte: CAST, 2003). 
As quatro substâncias são distinguidas com base nas suas fluorescências, ou seja, a aflatoxina $B_{1}\left(A F B_{1}\right)$ e a aflatoxina $B_{2}\left(A F B_{2}\right)$ emitem fluorescência azul (blue), $A$ aflatoxina $G_{1}\left(A F G_{1}\right)$ e a aflatoxina $G_{2}\left(A F G_{2}\right)$ emitem fluorescência verde (green). A. flavus produz somente as aflatoxinas $B_{1}$ e $B_{2}$, enquanto $A$. parasiticus e A. nomius produzem as quatro toxinas. As aflatoxinas são estáveis ao calor sendo decompostas à temperatura de cerca de $220^{\circ} \mathrm{C}$ (Van Der Zijden et al., 1962).

Foi demonstrado, em uma variedade de espécies animais, que a aflatoxina $\mathrm{B}_{1}$ é o mais potente carcinogênico de fígado que se conhece. A carcinogenicidade em animais é tão elevada que qualquer esforço deve ser feito para monitorar e reduzir os niveis em alimentos humanos (Pitt \& Hocking, 1999).

Uma das causas da extrema toxicidade da $A F B_{1}$ é devida a sua rápida absorção pelo sistema gastrointestinal, que facilita a sua entrada na circulação sangüinea, através da via portal, e o seu transporte para o fígado, que é o maior sítio de biotransformação da $A F B_{1}$, onde ocorre inicialmente a ativação metabólica dos componentes tóxicos e carcinogênicos, e subseqüentes reaçōes com macromoléculas e organelas celulares. A biotransformação ocorre pela ação de erizimas microssomais pertencentes à superfamilia de enzimas do citocromo P450, resultado em um composto reativo 8,9-epóxido, capaz de reagir, através de ligações covalentes, com sítios nucleofilicos de macromoléculas como o ácido desoxirribonucléico (DNA), ácido ribonucléico (RNA) e proteinas (Bennet e Klich, 2003).

A ligação do derivado epóxido com guaninas da molécula do DNA, na posição N7, forma adutos, os quais representam a lesão bioquimica primária produzida por aflatoxinas, modificando a estrutura do DNA e, conseqüentemente, sua atividade biológica, resultando em efeitos mutagênicos e carcinogênicos (Dalezios et al., 1973; Pitt et al., 2000). Além da epoxidação, a biotransformação das aflatoxinas inclui a formação de metabólitos hidroxilados, menos ativos, como 
as aflatoxinas $M, Q$ e $P$, hidrossolúvais e que podem ser rapidamenie excretadas (Oliveira e Germano, 1997).

Chourasia (1995) verificou a presença de aflatoxina $B_{1}$ em $43 \%$ de drogas vegetais $(0,05$ a $0,91 \mu \mathrm{g} / \mathrm{g})$ e Reif e Metzger (1995) verificaram a presença de aflatoxinas $B_{1}, B_{2}, G_{1}$ e $G_{2}$ em amostras de drogas vegetais e preparações derivadas. Roy et al. (1988), constataram que 93\% das 15 amostras de plantas medicinais coletadas do comércio na Índia, continham aflatoxinas como um contaminante natural (com concentrações entre 0,09 e $1,20 \mu \mathrm{g} / \mathrm{g}$ ) e que tais plantas eram destinadas para preparações tradicionais a fim de tratar uma moléstia. No entanto, o tratamento de uma doença com esse material pode levaria causar danos mais severos para saúde.

Um estudo realizado por Tassaneeyakul (2004) e colaboradores demonstrou que do total de 28 produtos derivados de plantas medicinais (tabletes e cápsulas), $18 \%$ apresentaram niveis detectáveis de aflatoxinas, variando de 1,7 a $14,3 \mathrm{ng} / \mathrm{g}$. Yang et al. (2005) relataram a presença de aflatoxinas em 14 amostras de drogas vegetais chinesas, tendo sido detectadas aflatoxina $B_{1}$ em 3 amostras $(1,58 ; 4,18 \mathrm{e}$ $27,80 \mu \mathrm{g} / \mathrm{g})$, aflatoxina $B_{2}$ em 3 amostras $(1,32 ; 5,16$ e $4,38 \mu \mathrm{g} / \mathrm{g})$ e aflatoxina $G_{1}$ em uma amostra $(1,31 \mu \mathrm{g} / \mathrm{g})$.

\subsection{Efeitos da radiação ionizante em fungos e em aflatoxinas}

Quando a radiação ionizante é absorvida por um material biológico, esta age diretamente em alvos críticos na célula. As moléculas de ácido nucléico podem ser ionizadas ou excitadas, e por meio disso, iniciar a cadeia de eventos que conduzem às mudanças biológicas e à morte celular. Este é o éfeito direio dia radiação, o qual é o processo dominante quando esporos secos de microrganismos são irradiados (Diehl, 1995). 
Alternativamente, a radiação pode interagir com outros átomos ou moléculas na célula, particularmente água, para produzirem radicais livres, os quais podem difundir-se, alcançar e danificar o DNA. Este efeito indireto da radiação é importante em células vegetativas, cujo citoplasma contém cerca de $80 \%$ de água (Diehl, 1995).

O tipo de irradiação utilizado no tratamento de alimentos se limita às radiações provenientes dos raios gama de alta energia, os raios $X$ e os elétrons acelerados (WHO, 1994). Após a determinação das doses e tratamento pelo processo de irradiação, as amostras são analisadas pela presença ou ausência de esporos sobreviventes, após a incubação $e$, o crescimento fúngico pode ser visualizado em piacas de Petri, contendo meio de cultivo específico para fungos (Aquino, 2003).

A capacidade de crescimento é perdida em baixas doses, entretanto, a idade das culturas pode influenciar consideravelmente a radiosensibilidade e por isso, experimentos conduzidos por diferentes autores, para determinar a sensibilidade à radiação de leveduras e bolores, não apresentem resultados idênticos, contudo, leveduras são geralmente mais resistentes do que bolores (Diehl, 1995).

As espécies do grupo Aspergillus, especificamente A. niger e A. flavus, foram mais freqüentes em 84 amostras de plantas medicinais estudadas por Aziz et al. (1997). Ainda neste estudo, foram isolados 9 gêneros fúngicos como Absidia, Aspergillus, Cladosporium, Penicillium, Paecilomyces, Fusarium, Rhizopus, Mucor e Scopulariopsis, sendo os gêneros Penicillium, Fusarium e Aspergillus considerados fungos toxigênicos e determinados os valores $D_{10}$ para as seguintes espécies: A. ochraceus $(0,36 \mathrm{kGy})$; A. parasiticus $(0,48 \mathrm{kGy})$; A. flavus $(0,52 \mathrm{kGy})$; A. fumigatus $(0,63 \mathrm{kGy}) ; F$. oxysporum $(0,76 \mathrm{kGy})$ e F. solani $(0,87 \mathrm{kGy})$. A sensibilidade de fungos à radiação ionizante já foi discutida por diversos autores, que citaram valores de doses compreendidas entre 4 a $10 \mathrm{kGy}$ para a completa 
inibição da contaminação fúngica natural em alimentos e especiarias (Sharma et al., 1984; El-Far et al., 1992; Aziz e El- Aal, 1990). Rowley et al. (1978) relatarom que os gêneros de fungos filamentosos apresentam uma resistência intermediéria à radiação ionizante, principalmente os gêneros Aspergillus e Penicillium. Sommer e Fortlage (1966) demonsiraram que a elevada resistência à radiação dos gêneros Alternaria e Fusarium se deve à multi-celularidade dos esporos.

Maity et al. (2004) demonstraram que doses de 1,0 kGy inibiram completamente os gêneros Rhizopus., Fusarium, Cladosporium e Trichoderma em arroz (Oryza sativa) e Drechslera spp. foi observada após o tratamerito com a dose de $2,0 \mathrm{kGy}$, enquanto Helminthosporium spp. e Curvularia spp. apresentaram 100\% de mortalidade quando expostas à dose de 3,0 kGy. Os autoies réataram que fungos do gênero Aspergillus spp. não sobreviveram após o tratamento com 4,0 kGy, entretanto, colônias de Alternaria spp. foram observadas no substrato irradiado.

A presença de água é um fator importante na degradação de aflatoxinas por radiação gama, uma vez que a radiólise da água prođuz radicais livies ałiamente reativos, que podem atacar diretamente o anel terminal furano da aflatoxina, gerando produtos de baixa atividade biológica (Rustom, 1997). Van Dick et al. (1982) demonstraram que a atividade mutagênica da $A F B_{1}$ em soluções aquosas $(5 \mu \mathrm{g} / \mathrm{mL})$ foi reduzida em $34,44,74$ e $100 \%$ nas doses de radiação gama de 2,5; 5; 10 e 20 kGy respectivamente.

Aquino e colaboradores (2005) demonstraram que a dose de 2 kGy de radiação gama associada à elevada atividade de água $(A a=0,91)$ de grãos de milho, inocuiados artificialmente com Aspergillus flavus toxigênico, degradou em $68,9 \%$ e $97,6 \%$ as aflatoxinas $B_{1}$ e $B_{2}$, presentes no substrato. 


\section{MATERIAIS E MÉTODOS}

\subsection{Amostras de plantas medicinais}

Cem amostras de drogas vegetais (Sene, Boldo, Espinheira santa, Chá verde e Guaraná em pó) sendo 20 amostras, para cada tipo de planta, foram adquiridas no comércio varejista (FIG. 2) e atacadista na região onde se localiza a Regional de Saúde DIR IV (Francisco Morato, Franco da Rocha, Cajamar e Mairiporã) e do município de São Paulo. As amostras coletadas em feiras apresentaram sua forma de venda à granel, expostas abertamente em sacarias nas bancas (FIG. 3 e 4). As drogas vegetais coletadas em farmácias apresentaram-se em embalagens, como potes plásticos e sacos plásticos individuais, nas formas de folhas ou pó (FIG. 5, 6 e 7). As amostras do atacado apresentaram-se em sacos plásticos de $500 \mathrm{~g}$ ou $1 \mathrm{~kg}$ (folhas, pó ou grãos), conforme mostrado nas figuras $8 \mathrm{e}$ 9.
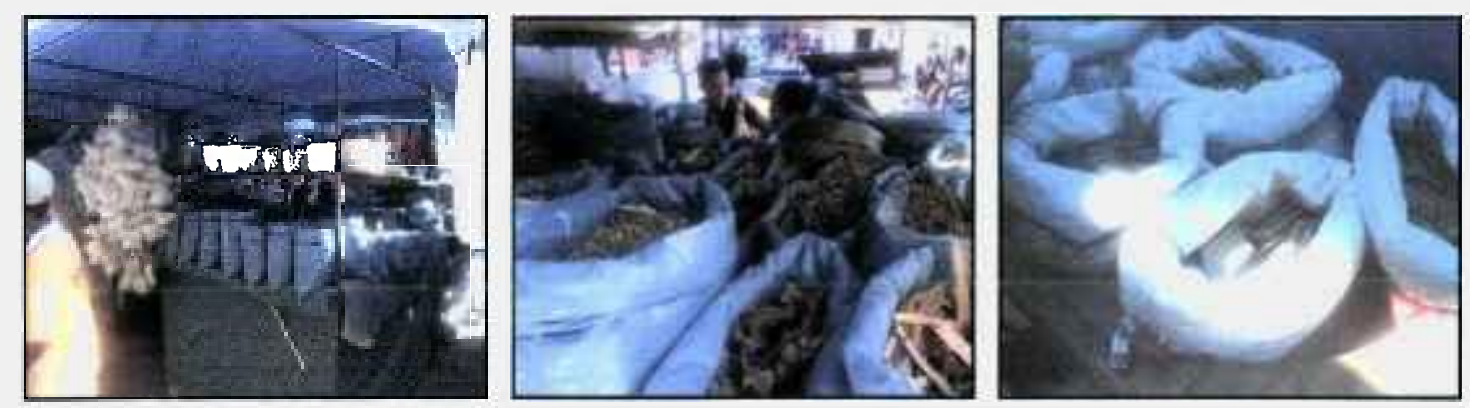

FIGURA 2, 3 e 4 . Pontos de venda em feira livre e apresentação d̀ granel em sacarias 

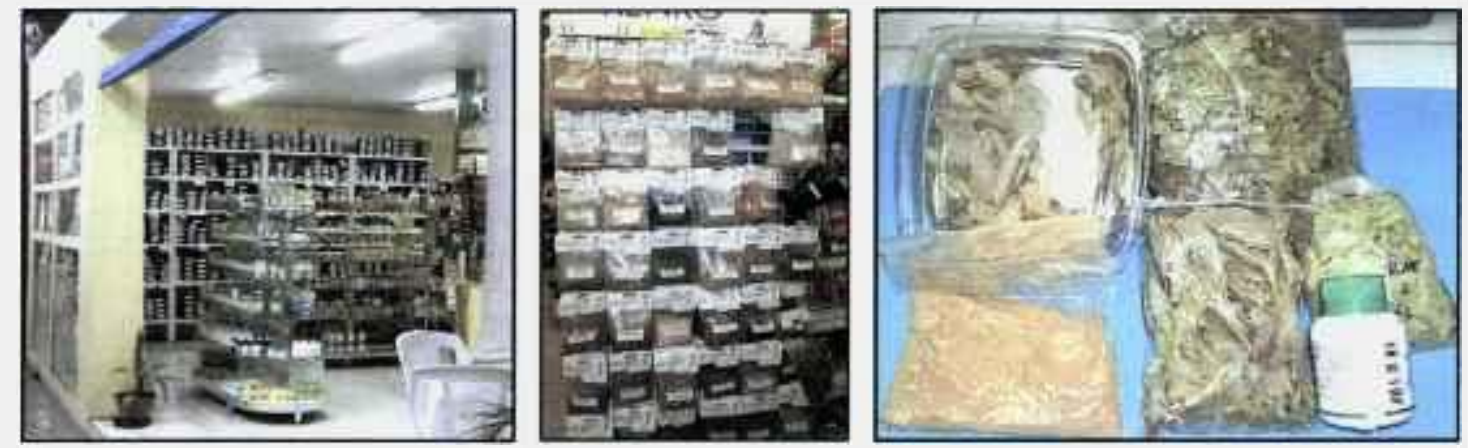

FIGURA 5, 6 e 7. Produtos dispostos em lojas especializadas e embalados

As amostras foram moídas e colocadas em sacos de polietileno envoltos em sacos de papel (FIG. 10 e 11), na quantidade de $10 \mathrm{~g}$ para análise da microbiota (em triplicata). Para o ensaio do perfil fitoquímico, foram necessários 200 gramas das amostras para cada grupo (controle, 5 e $10 \mathrm{kGy}$ ).

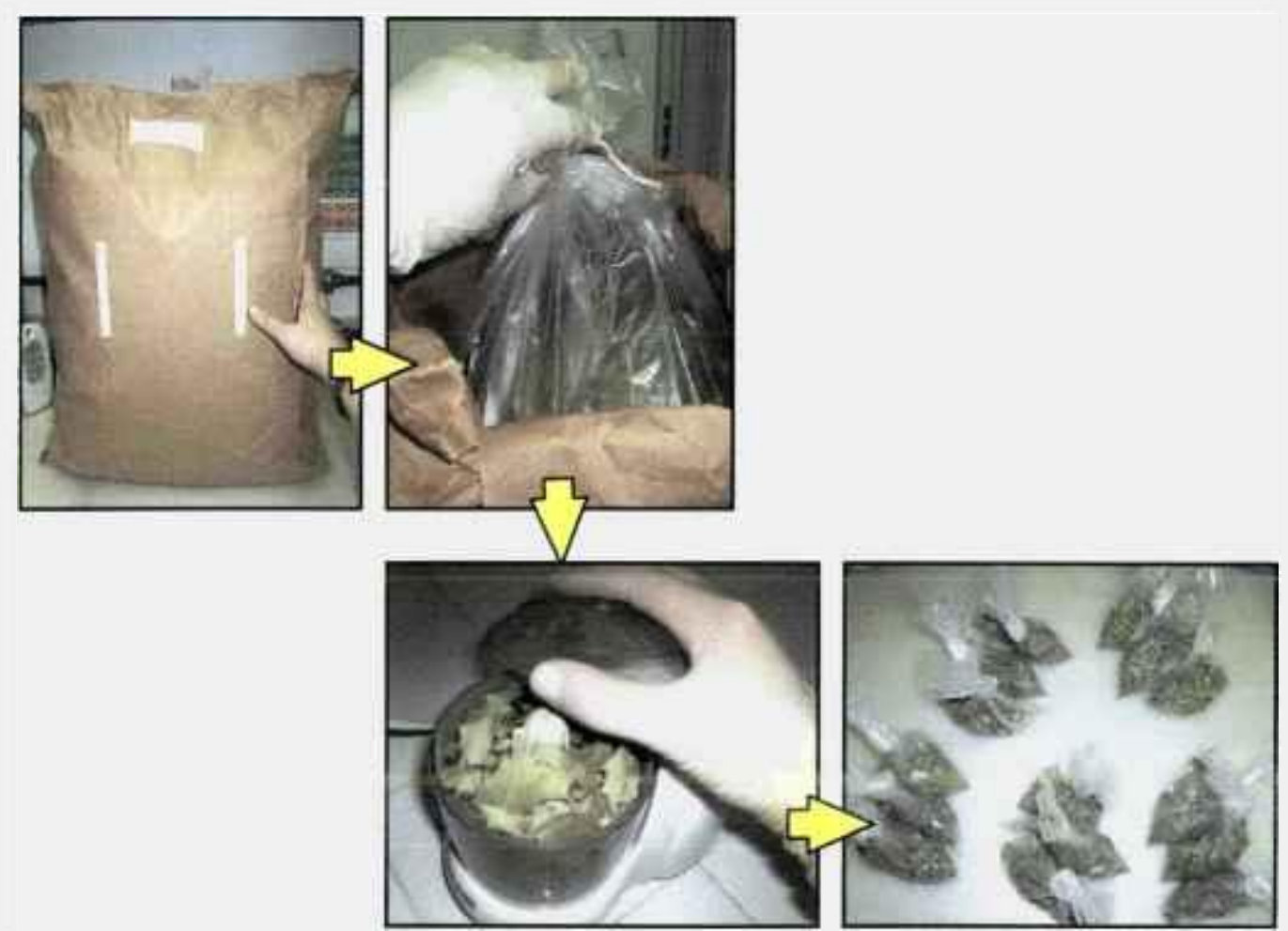

FIGURA 8, 9, 10 e 11. Fracionamento e preparo das amostras coletadas do mercado atacadista para análises em laboratório. 


\subsection{Tratamento pelo processo de irradiação}

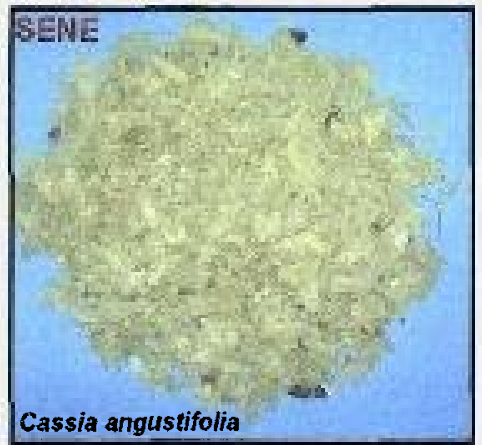

FIGURA 12. Sene

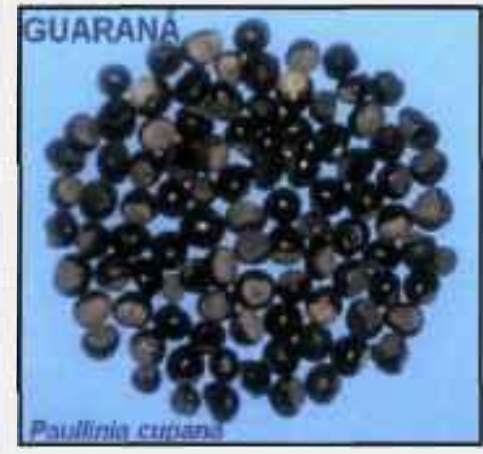

FIGURA 13. Guaraná

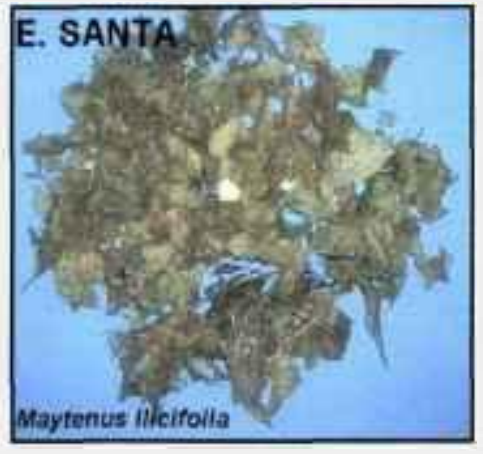

FIGURA 14. Espinheira santa

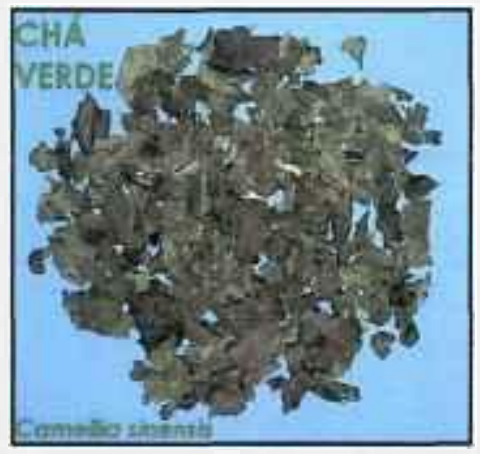

FIGURA 15. Chá verde

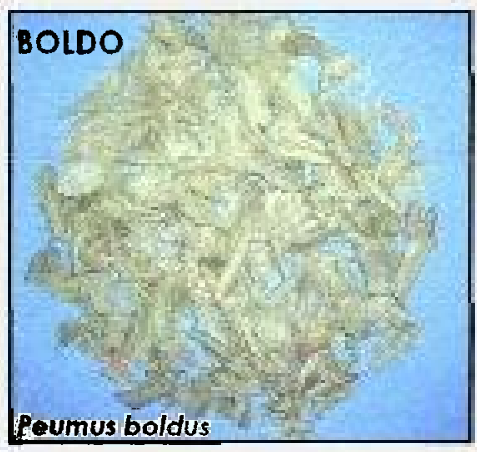

FIGURA 16. Boldo

As amostras (FIG. 12, 13, 14, 15 e 16) foram tratadas pelo processo de radiação ionizante com a dose de 5 e 10 kGy (FIG. 17 e 18) no Instituto de Pesquisas Energéticas e Nucleares (IPEN - CNEN/SP) - Fonte Gammacell ( ${ }^{6} \mathrm{Co}$ ) (FIG.19), com taxa de dose variando no período do estudo, entre $3,36 \mathrm{kGy} / \mathrm{h}$ a $3,50 \mathrm{kGy} / \mathrm{h}$. 
As amostras foram submetidas à pesquisa de microbiota, atividade de água, alteração do perfil fitoquímico e determinação de micotoxinas, após o processo de irradiação. O grupo controle (não irradiado) foi analisado paralelamente com as amostras irradiadas. As etapas de detecção da microbiota fúngica, atividade de água, micotoxinas e perfil fitoquímico foram desenvolvidas no Laboratório de Micotoxinas do ICB II-USP e Instituto Biológico de São Paulo.
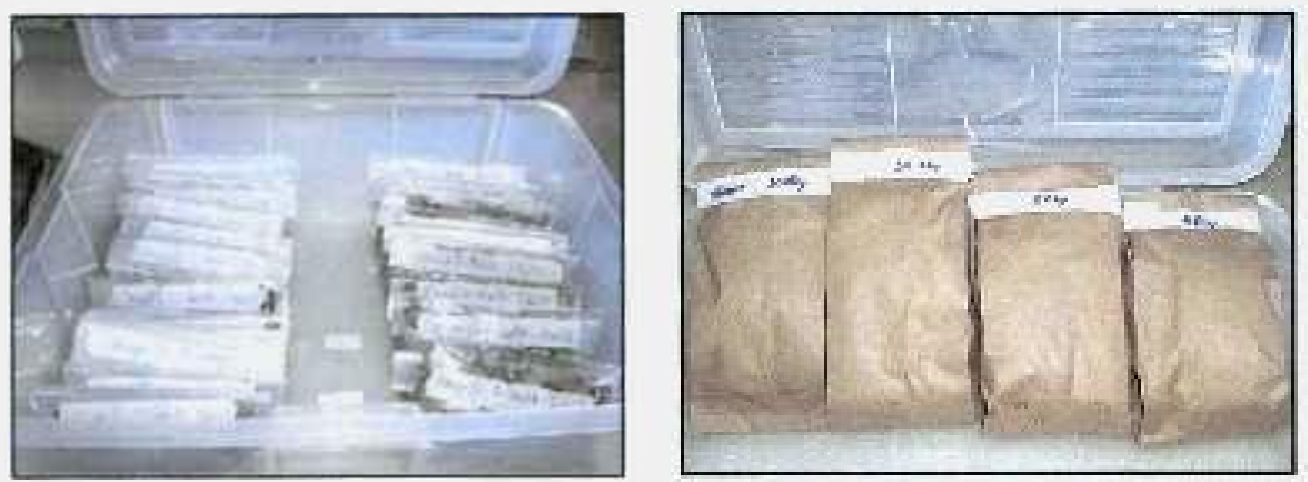

FIGURA 17 e 18. Amostras embaladas para o tratamento pelo processo de irradiação.

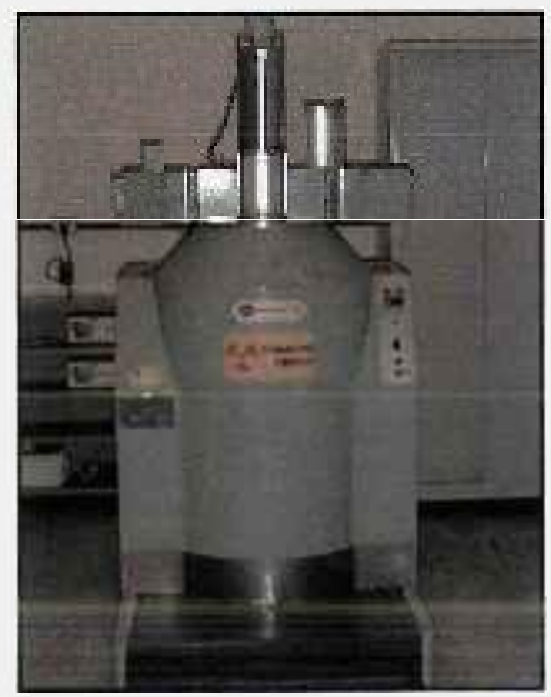

FIGURA 19. Fonte Gammacell - ${ }^{\infty}$ Co (IPEN - CNEN/SP), 


\subsection{Determinação de atividade de água (Aa)}

Os valores de $A a$ das amostras foram obtidos utilizando-se equipamento AQUALAB CX-2, da Decagon Devices Inc. (FIG. 20). Esta etapa foi realizada no laboratório de Micotoxinas do Departamento de Microbiologia do ICB II-USP.

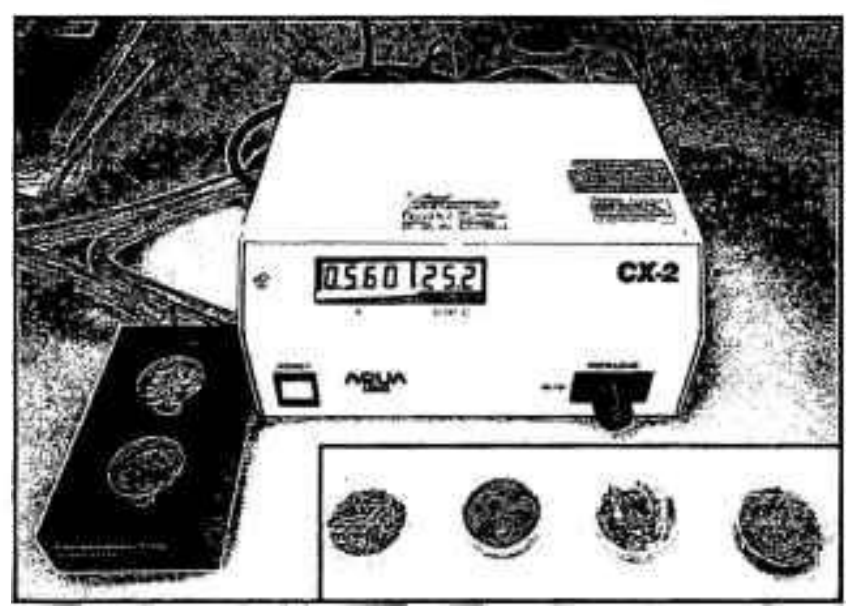

FIGURA 20. Equipamento Aqualab do Laboratorio de Micotoxinas (ICB II-USP) utilizado na determinaçăo da Aa

\subsection{Isolamento da microbiota fúnglca das amostras}

As amostras foram pesadas e alíquotas de $10 \mathrm{~g}$ foram colocadas em frascos de vidro contendo $90 \mathrm{~mL}$ de água destilada estéril, agitadas por 30 minutos $e$ aliquotas de $1,0 \mathrm{~mL}$, repassadas em diluiçōes seriadas de $10^{-1}$ a $10^{-6}$, em tubos de ensaio estéreis. Uma fração de $0,1 \mathrm{~mL}$ foi semeada superficialmente, em placas de Petri (em duplicata) contendo ágar Dicloran Glicerol 18\% (DG18 - OXOID) e, posteriormente, incubadas por 6 dias na temperatura de $25^{\circ} \mathrm{C}$, em estufa com temperatura controlada (FIG. 21 e 22). 


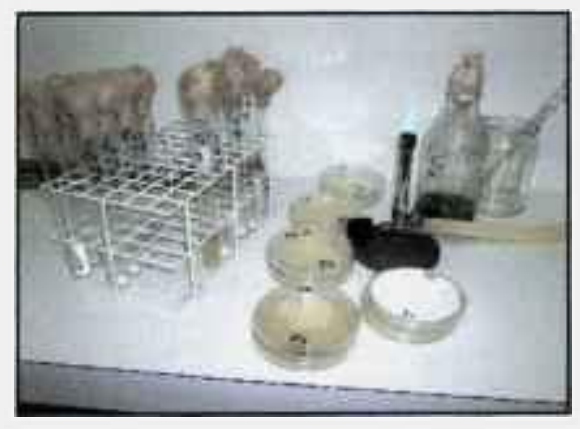

FIGURA 21. Isolamento da microbiota.

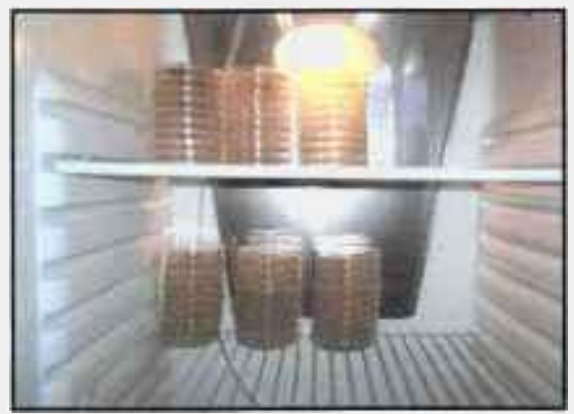

FIGURA 22. Incubaçåo das placas a $25^{\circ} \mathrm{C}$

A contagem foi determinada por unidades formadoras de colônias por grama de substrato (UFC/g) (Pitt et al., 1983). Colônias de diferentes tipos morfológicos foram isoladas em ágar Batata Dextrose e submetidas à técnica de micro-cultivo (Riddell, 1950).

Os fungos foram classificados até gênero, conforme as características microscópicas (FIG. 23 e 24), entretanto aqueles pertencentes do gênero Aspergillus foram classificados, até espécie, de acordo com os seguintes compêndios: Raper e Fennell, 1965; Arx, 1974.

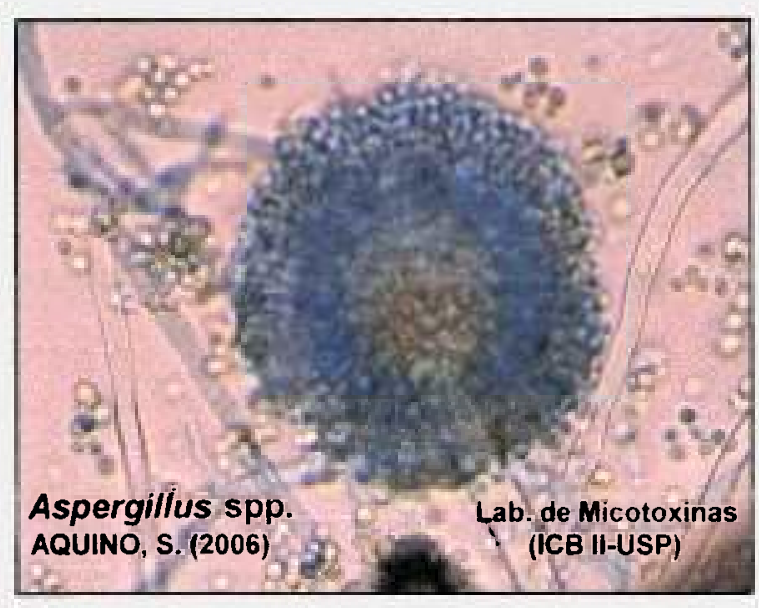

FIGURA 23. Imagem de microscopia óptica de Aspergillus spp.

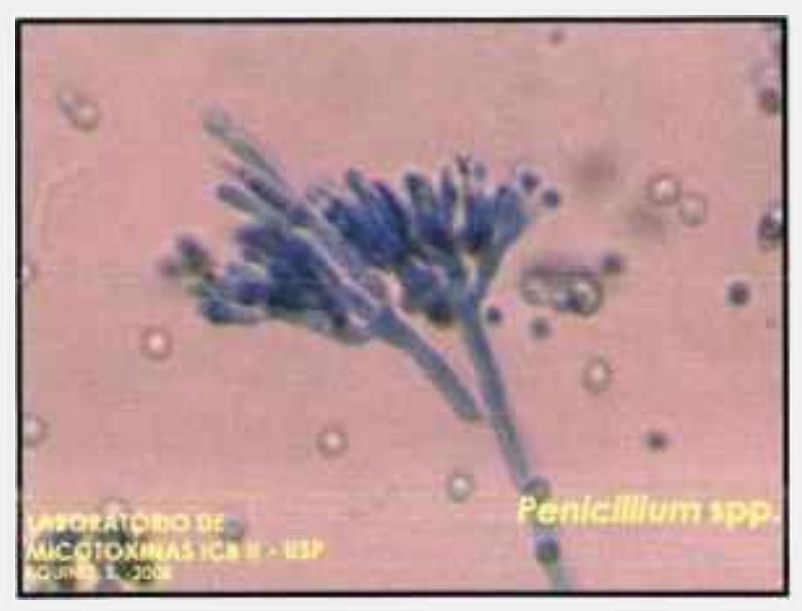

FIGURA 24. Imagem de microscopia óptica de Penicillium spp. 


\subsection{Potencial toxigênico das cepas de Aspergillus flavus isolados}

Para a análise da produção de toxinas e posterior extração das aflatoxinas, as cepas de $A$. flavus e $A$. parasiticus isoladas das amostras cultivadas em ágar DG 18, foram previamente isoladas em ágar batata dextrose por 10 dias e, posteriormente inoculadas no centro de uma placa de Petri contendo ágar côco, (Lin e Dianese, 1976) com o auxílio de uma alça em "L" (FIG. 25) e mantidas durante 14 dias à temperatura de $25^{\circ} \mathrm{C}$, em estufa.

Após o crescimento, todo material contido no ágar côco (cultivo) foi pesado e transferido para um frasco de boca larga, sendo adicionado clorofórmio na proporção de $10 \mathrm{~g}$ de cultivo para $30 \mathrm{~mL}$ de clorofórmio. Após agitação de 30 minutos, em agitador mecânico horizontal (FIG. 26), o conteúdo do frasco foi filtrado em papel de filtro contendo sulfato de sódio anidro e terra diatomácea. $O$ filtrado então, evaporado até atingir a secura em Banho-Maria a $80^{\circ} \mathrm{C}$, em capela de segurança química. O resíduo foi armazenado em temperatura de congelamento em tomo de $-20{ }^{\circ} \mathrm{C}$, até a realização da cromatografia em camada delgada, conforme descrito por Soares \& Rodriguez-Amaya (1989).
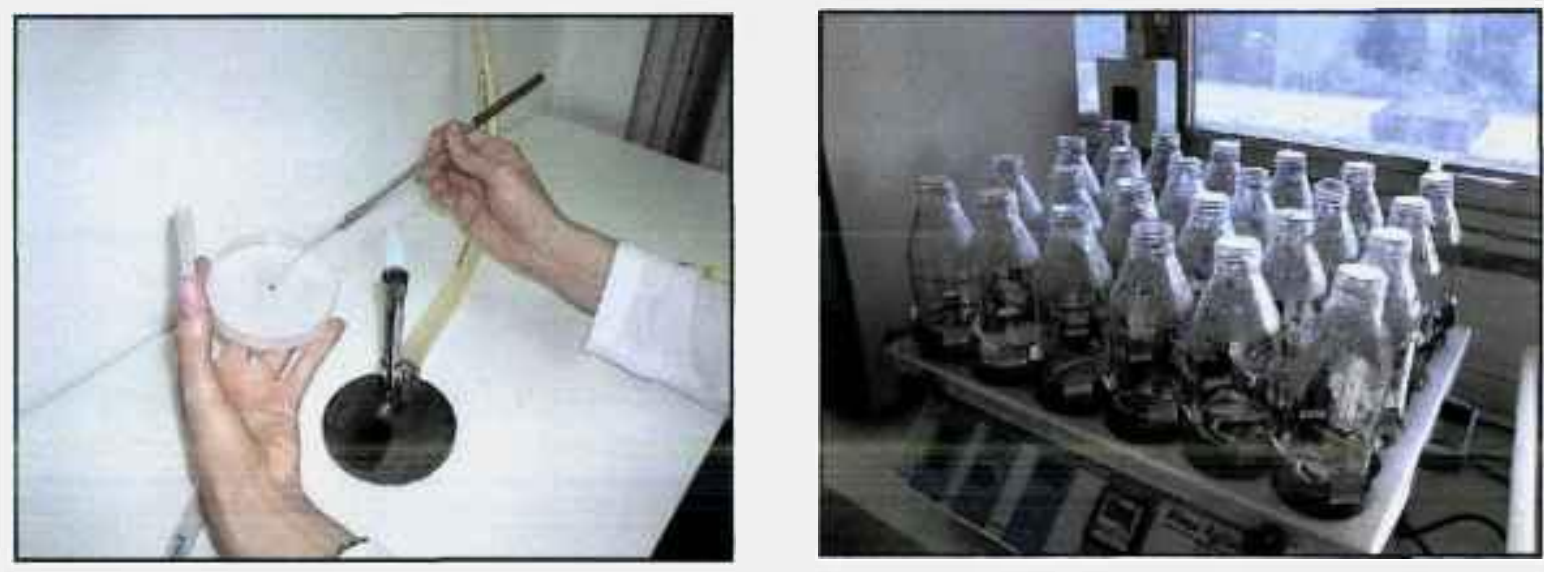

FIGURA 25 e 26. Teste de potencial toxigénico em ágar cóco de Aspergillus spp. 
4.6 Análise da presença de aflaroxinas nas amostras

A extração, purificação e confirmação das aflatoxinas nas amostras de plantas medicinais foram determinadas seguindo-se a metodologia desenvolvida por Soares \& Rodriguez-Amaya (1989) e com uso de colunas de imunoafinidade (Kit AflatestßB VICAM).

\subsubsection{Método Soares \& Rodriguez-Amaya (1989).}

Em cada erlenmeyer contendo $50 \mathrm{~g}$ de amostra, foram adicionados $270 \mathrm{~mL}$ de metanol e $30 \mathrm{~mL}$ de solução de cloreto de potássio ( $\mathrm{KCl} 4 \%$ ). Após agitação de 30 minuios, o conteúdo do frasco foi filtrado em papel de filtro e uma alíquota de $150 \mathrm{~mL}$ foi retirada e transferida para um béquer de $600 \mathrm{~mL}$.

Foram adicionados à alíquota $150 \mathrm{~mL}$ de solução de sulfato de amônia e 50 $\mathrm{ml}$ de terra diatomácea. A suspensão foi filtrada e desta, $150 \mathrm{~mL}$ foi transferido para funil de separação e, adicionados $150 \mathrm{~mL}$ de água e $20 \mathrm{~mL}$ de clorofórmio.

A mistura foi agitada e após separação da fase, a camada inferior, a clorofórmica, foi extraída. Foram adicionados, novamente, $20 \mathrm{~mL}$ de clorofórmio. A mistura foi agitada e, após a separação de fase, a camada inferior foi também extraída. O filtrado então, evaporado até atingir a secura em Banho-Maria a $80^{\circ} \mathrm{C}$, em capela de segurança química. 


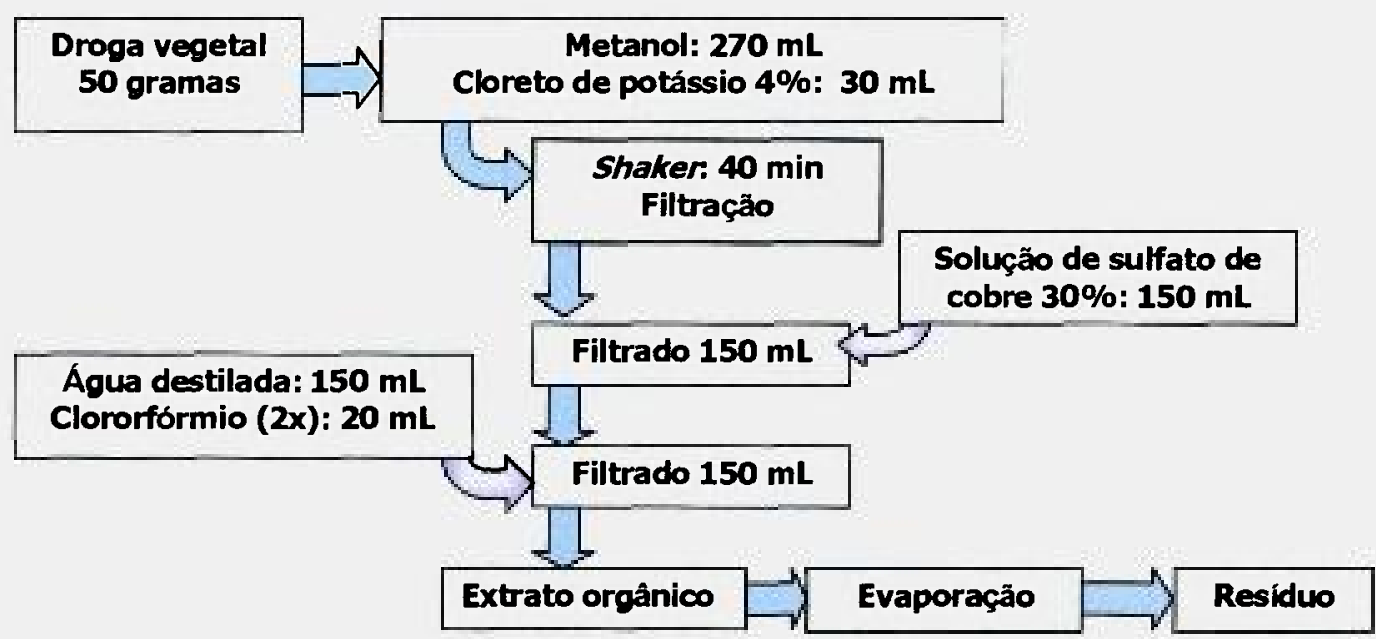

FIGURA 27. Esquema de extração de aflatoxinas (Soares \& Rodriguez-Amaya-1989)

O residuo foi armazenado na temperatura de $-20^{\circ} \mathrm{C}$, até a realização da cromatografia em camada delgada (CCD), conforme descrito por Soares \& Rodriguez-Amaya (1989) e mostrado no diagrama esquemático na FIG. 27.

\subsubsection{Imunoextração (coluna de imunoafinidade)}

A técnica de imunoextração refere-se à utilização de colunas de imunoafinidade para a remoção do analito ou grupo de analitos de uma amostra antes de sua determinação, quantitativa ou qualitativa. Envolve a adsorção do analito presente no extrato, seguida de posterior liberação e detecção.

A coluna de imunoafinidade é um tipo de coluna em fase sólida, contendo anticorpos imobilizados em um suporte inerte. O extrato da amostra é aplicado na coluna, sendo a micotoxina presente, adsorvida pelos anticorpos imobilizados na coluna, separando de outros componentes do extrato que não são retidos e são eliminados (FIG. 28). 
A micotoxina é removida pelo uso de eluente adequado, que rompe a ligação micotoxina-anticorpo, liberando a micotoxina para ser detectada.

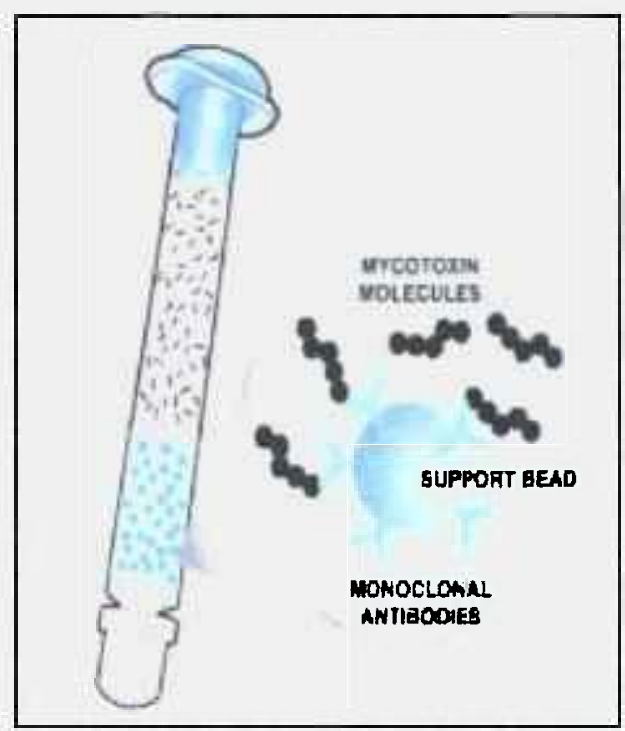

FIGURA 28. Coluna Aflatest ${ }^{\text {- }}$ VICAM

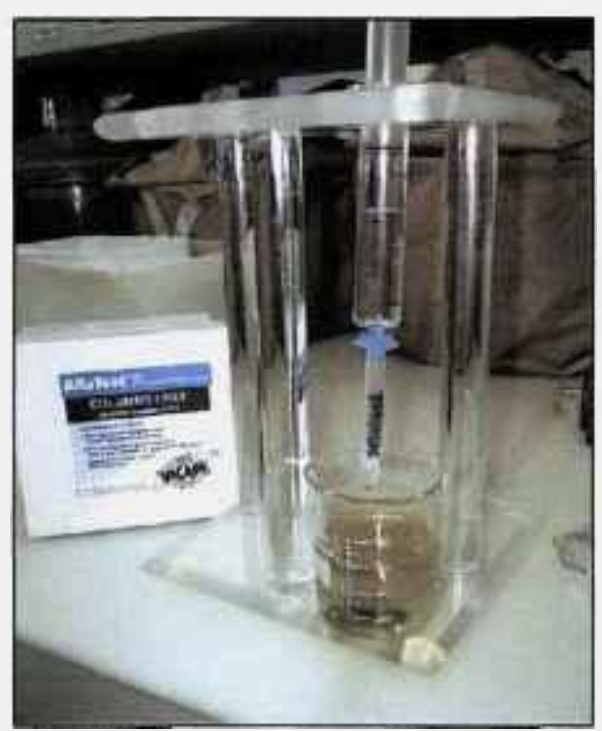

FIGURA 29. Uso da coluna laboratório de Micotoxinas (CB IIUSP).

O método empregado no presente estudo foi uma modificação proposta por Bugno (2006). Sobre a alíquota de $5 \mathrm{~g}$ da amostra, foram adicionados $30 \mathrm{~mL}$ de metanol a $70 \%$ e $1 \mathrm{~g}$ de cloreto de sódio e em seguida as amostras foram colocadas em agitador tipo Shaker por 40 minutos e, em seguida, filtrada. Aos 20 $\mathrm{mL}$ do filtrado, foram adicionados $50 \mathrm{~mL}$ de solução aquosa de Tween $20^{\circledR}$ a $1 \%$.

A mistura foi submetida à agitação por 5 minutos e filtrada novamente. $A$ coluna foi pré-condicionada com $10 \mathrm{~mL}$ de água destilada e $10 \mathrm{~mL}$ de solução aquosa de Tween $20^{\circledR}$ a $1 \%$, com fluxo de $3 \mathrm{~mL} / \mathrm{min}$. Em seguida, $50 \mathrm{~mL}$ do filtrado foi aplicado na coluna Aflatest ${ }^{\circledR}$ (fluxo de $3 \mathrm{~mL} / \mathrm{min}$ ) e lavado com duas porções de $10 \mathrm{~mL}$ de água destilada, secado com ar por 2 a 3 segundos. A aflatoxina foi eluída da coluna com duas porções de $1,0 \mathrm{~mL}$ de metanol, com fluxo de $1 \mathrm{~mL} / \mathrm{min}$ e 0 
eluato coletado em frasco de vidro e evaporado em Banho-Maria a $80^{\circ} \mathrm{C}$ e congelado a $-20^{\circ} \mathrm{C}$ (FIG. 29). O processo é mostrado no diagrama apresentado na FIG. 30.

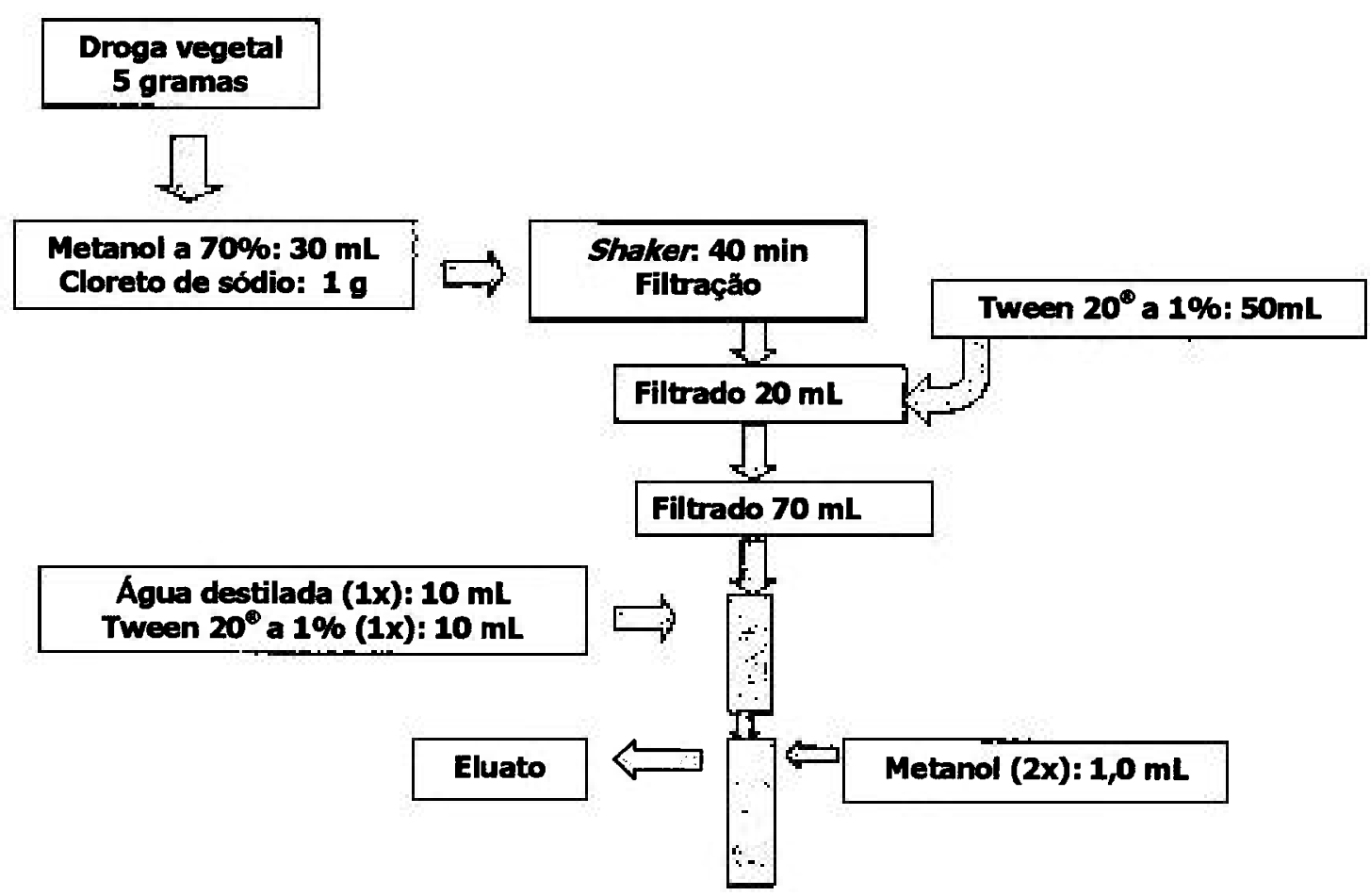

FIGURA 30. Imunoextraçăo de aflatoxinas por coluna de imunoafinidade (Bugno, 2006).

\subsection{Cromatografia em Camada Delgada}

Os resíduos das extrações (previamente descritas) foram descongelados e ressuspensos em $500 \mu \mathrm{L}$ de clorofórmio e alíquotas de $10 \mu \mathrm{L}$ do extrato foram aplicadas na cromatofolha, a $2,0 \mathrm{~cm}$ da base inferior da placa. Os padröes de aflatoxinas $B_{1}, B_{2}, G_{1} \in G_{2}$ foram aplicados na quantidade de $3 \mu \mathrm{L}$, formando spots ou manchas, com distância de $0,5 \mathrm{~cm}$ entre elas. 
O cromatograma (FIG. 31) foi obtido a temperatura ambiente, em cuba com sistema de solventes composto por clorofórmio e acetona $(9: 1 \mathrm{v} / \mathrm{v})$ e a visualização, após secagem da placa, foi realizada sob luz ultravioleta (365 nm) para confirmação das fluorescências características entre as amostras e os padrões.

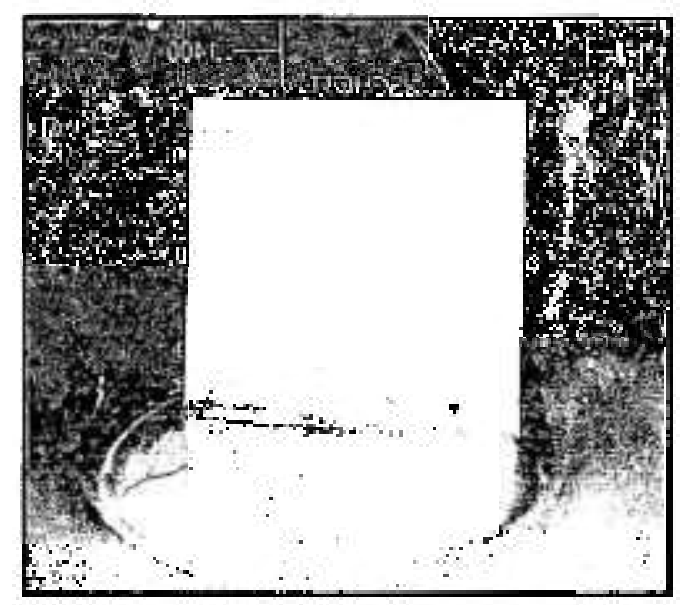

FIGURA 31. Cromatografia em camada delgada (CCD).

\subsection{Quantificação}

A quantificação realizada por fotodensitômetro marca Shimadzu, modelo CS 9000 com lâmpada de xenônio e $\lambda$ de $366 \mathrm{~nm}$ (equipamento pertencente ao Instituto Biológico de São Paulo, cujo limite de detecção é de $0,1 \mu \mathrm{g} / \mathrm{kg}$ ).

\subsection{Testes fitoquímicos qualitativos}

As amostras (200 g para cada amostra de Sene, Boldo, Espinheira santa, Guaraná em pó e Chá verde), foram secas em estufa a $40^{\circ} \mathrm{C}$, moídas e divididas em dois lotes, sendo um macerado com hexano e outro com etanol frio. $O$ processo foi repetido três vezes com intervalo de 24 horas. 
O solvente foi filtrado e evaporado sob pressão reduzida em um rotaevaporador obtendo-se um residuo, chamado extrato hexânico bruto (EHB) e extrato etanólico bruto (EEB), processo este realizado para as amostras irradiadas e o grupo controle (FIG. 32 e 33 ).

As soluções utilizadas, para os testes fitoquímicos qualitativos, foram preparadas com reagentes e solventes P. A. (Merck, Sigma).

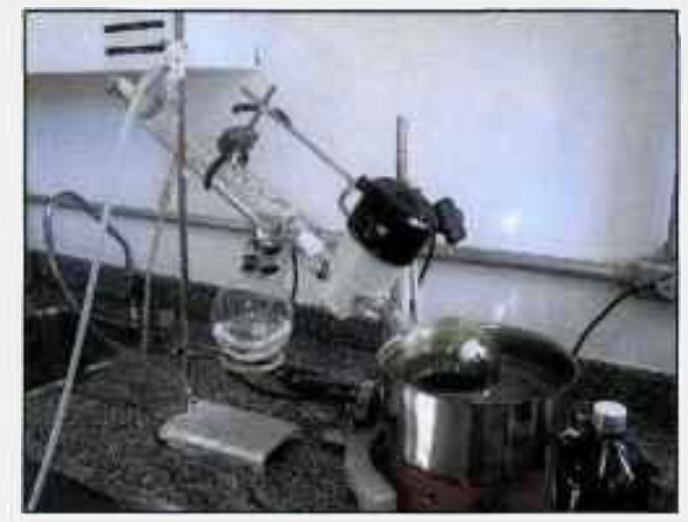

FIGURA 32. Rotaevaporador (Instituto Biológico)

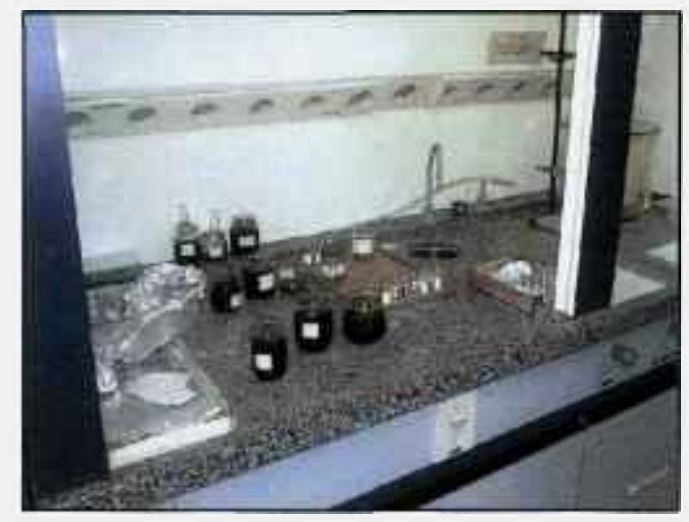

FIGURA 33. Extratos obtidos após secagem

Para as separações por cromatografia em camada delgada comparativa (CCDC), foram utilizadas: sílica gel $60 \mathrm{G}(5-40 \mu \mathrm{m}$ - Merck), suspensa em água destilada e distribuida em camadas sobre lâminas de vidro $(0,25 \mathrm{~mm})$ e cromatofolhas de alumínio Merck silicagel $60 \mathrm{~F}_{254}$.

Os EHB e EEB dos tratamentos foram aplicados em placas de silica gel $60 \mathrm{G}$ e em cromatofolhas de alumínio Merck sílica gel $60 \mathrm{~F}_{254}$ e foram submetidos à cromatografia em camada delgada comparativa, eluindo-se nas seguintes misturas: Hexano $($ Hex $) /$ Acetato de etila $($ AcOEt $)=2: 8$; Hex/AcOEt $=7: 3$; Clorofórmio $\left(\mathrm{CHCl}_{3}\right) /$ Etanol $(\mathrm{EtOH})=9: 1$. As placas de silicagel $60 \mathrm{G}$ foram reveladas com iodo 
e as placas fluorescentes foram reveladas no ulitravioleta (254 e $360 \mathrm{~nm}$ ). O processo experimental é apresentado de forma esquemática na FIG. 34. 


\section{DELINEAMENTO EXPERIMENTAL:}

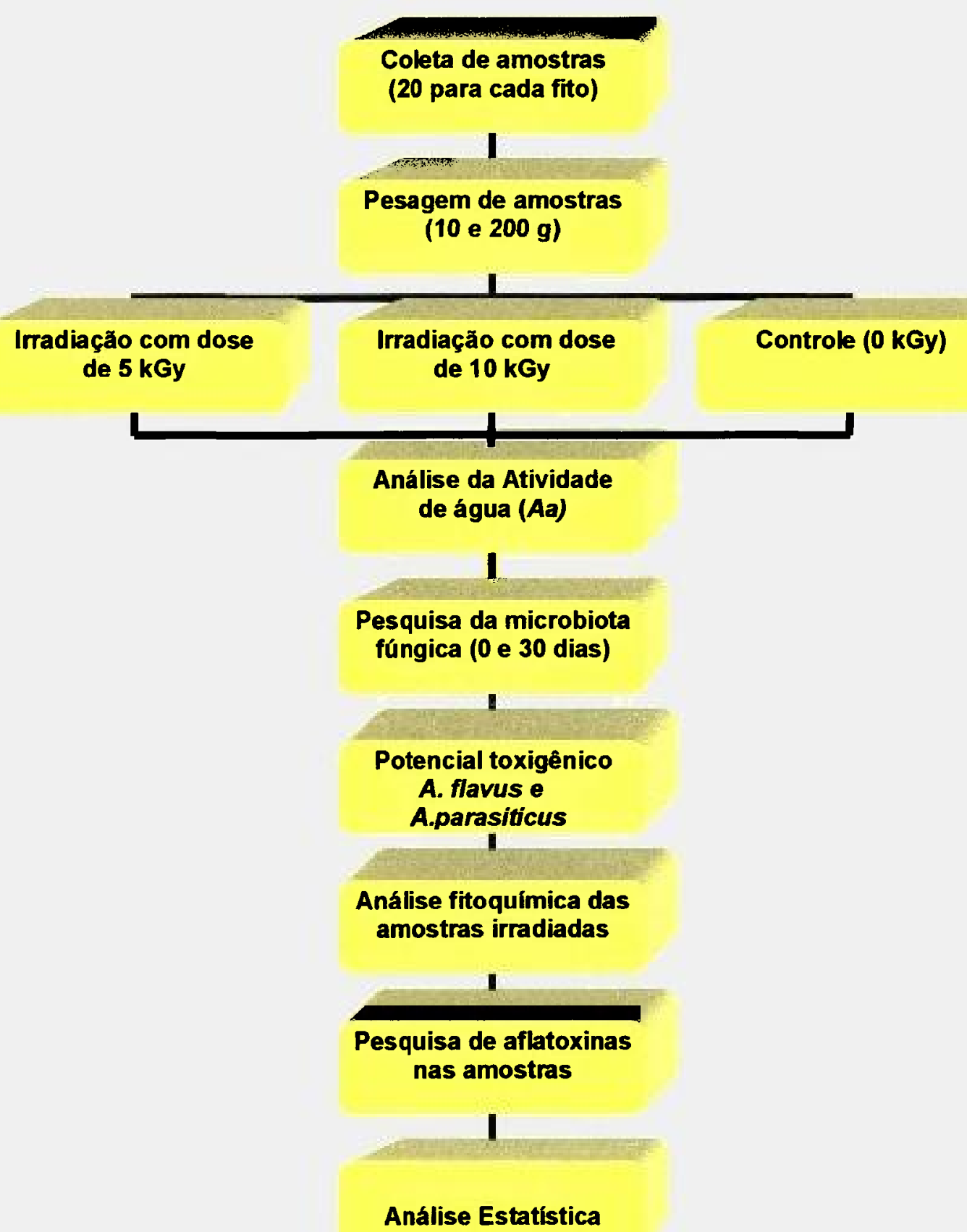

FIGURA 34. Representação esquemática das etapas do experimento 


\section{RESULTADOS}

\subsection{Determinaçẽo da atividade de água $(A a)$}

Os valores obtidos da atividade de água $(A a)$ das amostras controle variaram entre 0,51 a 0,58 , não diferindo estatisticamente das amostras irradiadas com 5 kGy ( $p>0.05)$, que apresentaram valores entre 0,49 e 0,55 e das amostras irradiadas com $10 \mathrm{kGy}$ estavam compreendidos entre 0,47 a 0,53 , demonstrando uma redução da $A a$, comparativamente ao grupo controle ( 0 kGy) onde uma diferença significativa $(p<0,05)$ ocorreu nas amostras de Guaraná, Boldo e Sene (TAB.2).

TABELA 2. Atividade de água das amostras controle (C), irradiadas com $5 \mathrm{kGy}$ (5) e irradiadas com $10 \mathrm{kGy}(10)$ de drogas vegetais, adquiridas do mercado atacadista e varejista:

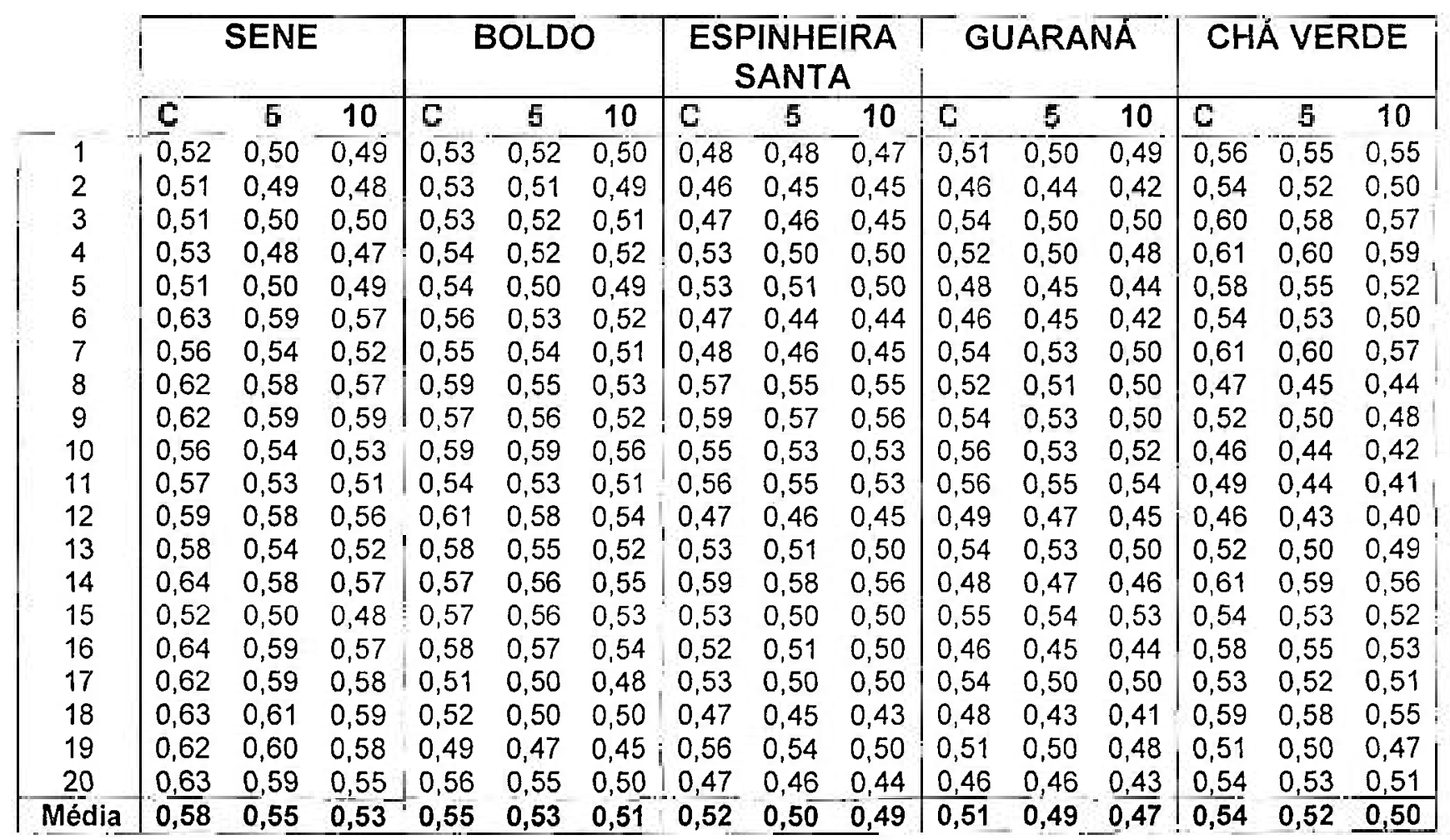




\subsection{Pesquisa da microbiota fúngica do grupo controle}

Do total de 100 amostras analisadas, no presente estudo, 95\% apresentaram contaminação fúngica (FIG. 35). Em relação à freqüência relativa dos gêneros fúngicos, os isolados do grupo controle de Boldo foi de: $75 \%$ Aspergillus; $12 \%$ Mucor, $7 \%$ Penicillium; 4,8\% Cladosponium; 0,7 \% Fungo Não Esporulado (FNE); 0,1\% Phoma; 0,1\% Cephalosporium e 0.02\% Absidia (FIG. 36). Em relação às espécies isoladas do gênero Aspergillus, foram encontrados: $67,3 \%$ de $A$. restrictus; $21 \%$ de $A$. flavus; $11 \%$ de $A$. niger; $0,25 \%$ de $A$ ochraceus; $0,12 \%$ de A.amstelodami e $0,06 \%$ de $A$. parasiticus (FIG. 37 ).

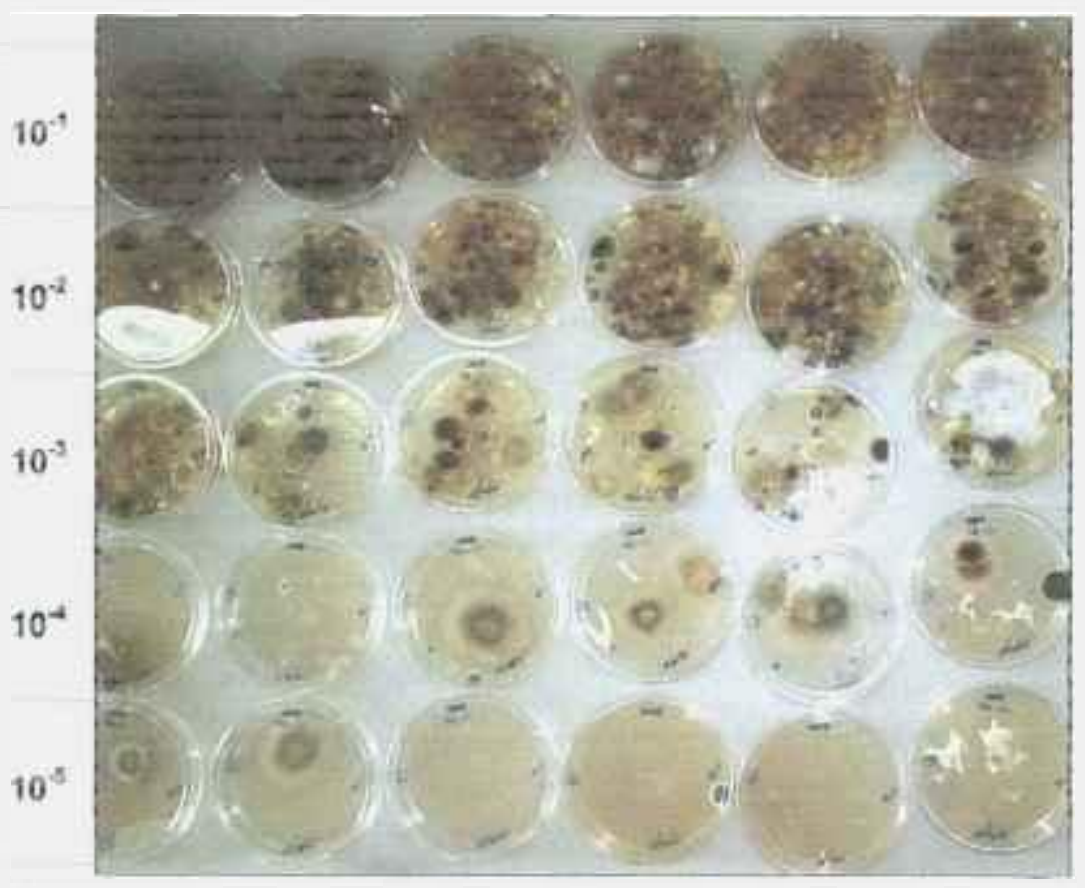

FIGURA 35. Isolados fíngicos eml placas de Petri (dilurções de $10^{-}$a $10^{\circ}$ ). 


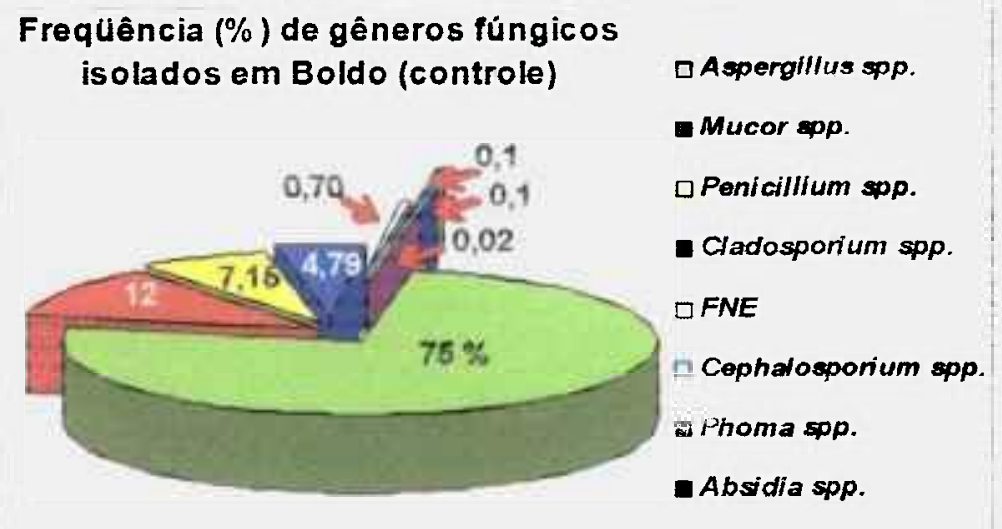

FIGURA 36. Freqüência de gêneros de fungos isolados em amostras de Boldo (não irradiadas).

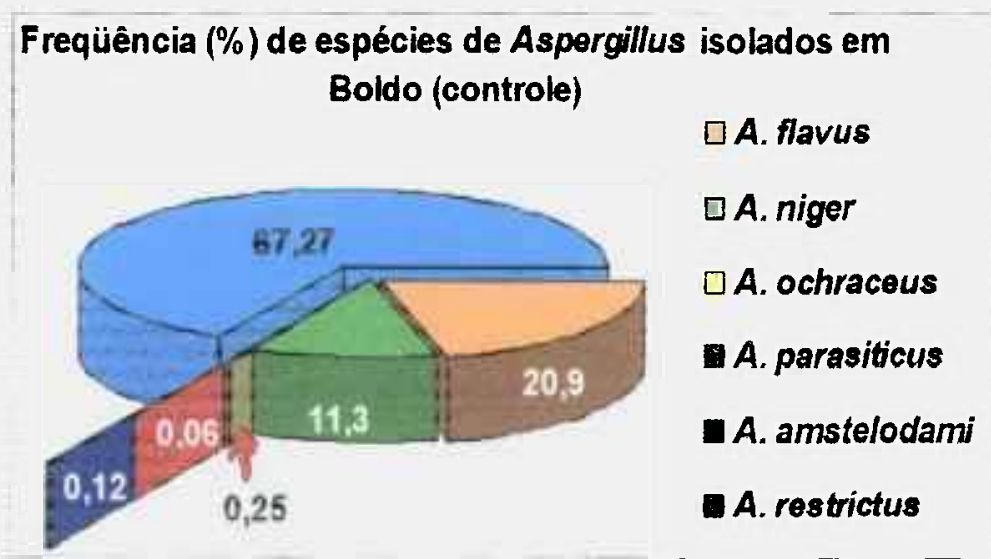

FIGURA 37. Freqüência de espécies de Aspergillus isolados em amostras de Boldo (não irradiadas).

As amostras do grupo controle de Espinheira santa apresentaram a freqüência relativa de gêneros isolados de: $28 \%$ de Aspergillus; $16 \%$ de Penicillium; 14\% de Fungo Não Esporulado (FNE); $12 \%$ de Mucor, 10\% de Absidia: $9 \%$ de Wallimia; $3 \%$ de Cephalosporium: $3 \%$ de Fusarium; 2\% de Syncephalastrum e 1.6 $\%$ de Cladosporium (FIG. 38 e 39 ). 


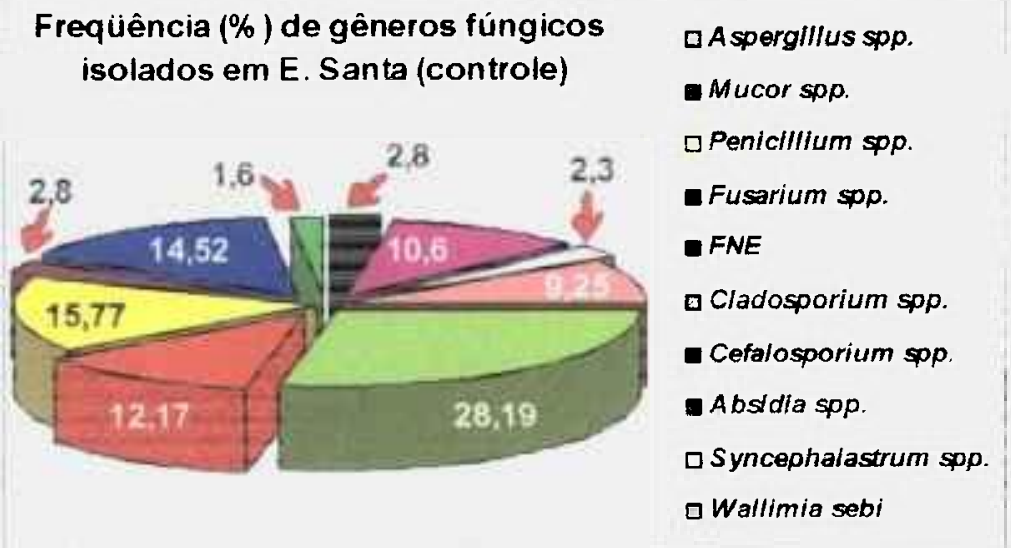

FIGURA 38. Freqüência de gêneros de fungos isolados em amostras de Espinheira santa (não irradiadas).

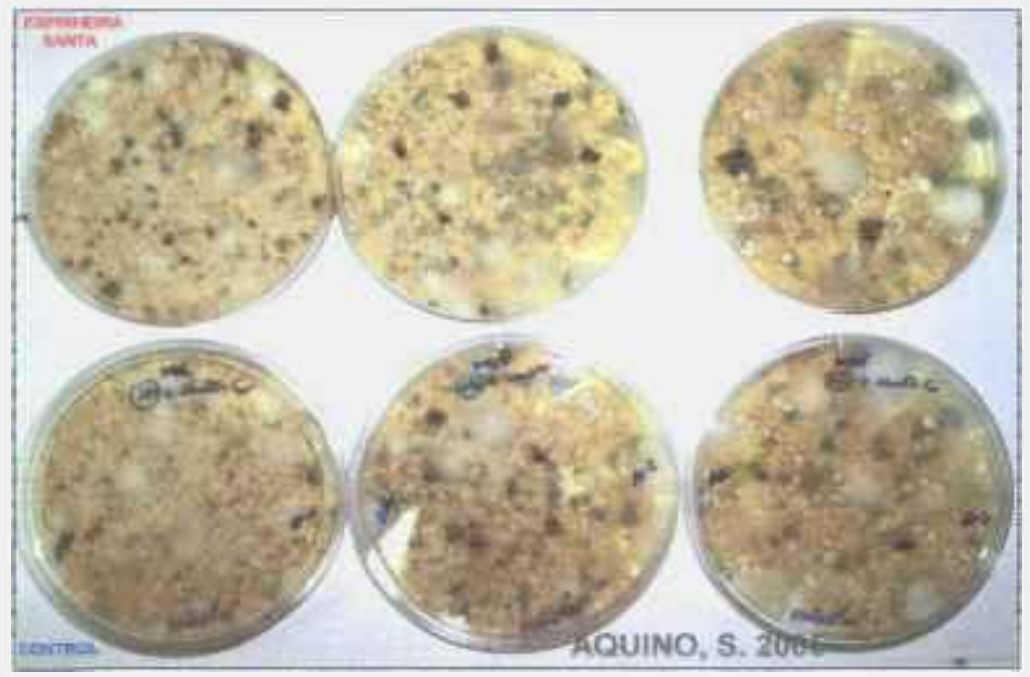

FIGURA 39. Isolados fúngicos do grupo controle de Espinheira santa

Em relação aos $28 \%$ do gênero Aspergillus, as espécies isoladas foram: $66 \%$ de $A$. flavus; $22 \%$ de $A$. niger, $8 \%$ de $A$. restrictus; $2 \%$ de $A$. glaucus e $1,8 \%$ de A. ochraceus (FIG. 40). 


\section{Freqüência $(\%)$ de espécies de Aspergillus} isolados em $\mathrm{E}$. Santa (controle)

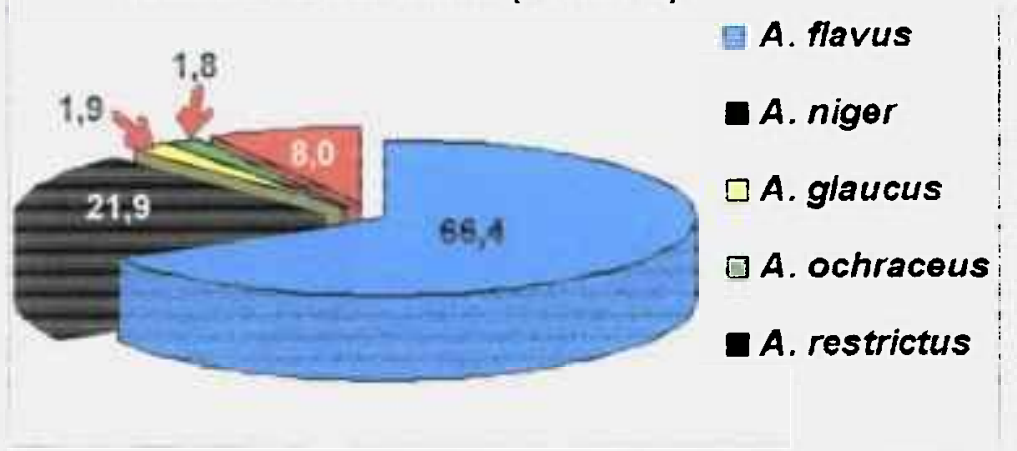

FIGURA 40. Freqüência de espécies de Aspergillus isolados em amostras de Espinheira santa (não irradiadas).

Quanto ao grupo controle de Sene, observou-se a seguinte freqüência relativa (\%) de gêneros de fungos isolados: $48 \%$ de Aspergillus; $32 \%$ de Cladosporium; $9 \%$ de Penicillium; $6 \%$ de Phoma; $1,8 \%$ de FNE; $1 \%$ de Cephalosporium; $0,9 \%$ de Syncephalastrum; $0,8 \%$ de Fusarium; 0,5\% de Mucor e $0.3 \%$ de Absidia (FIG.41)
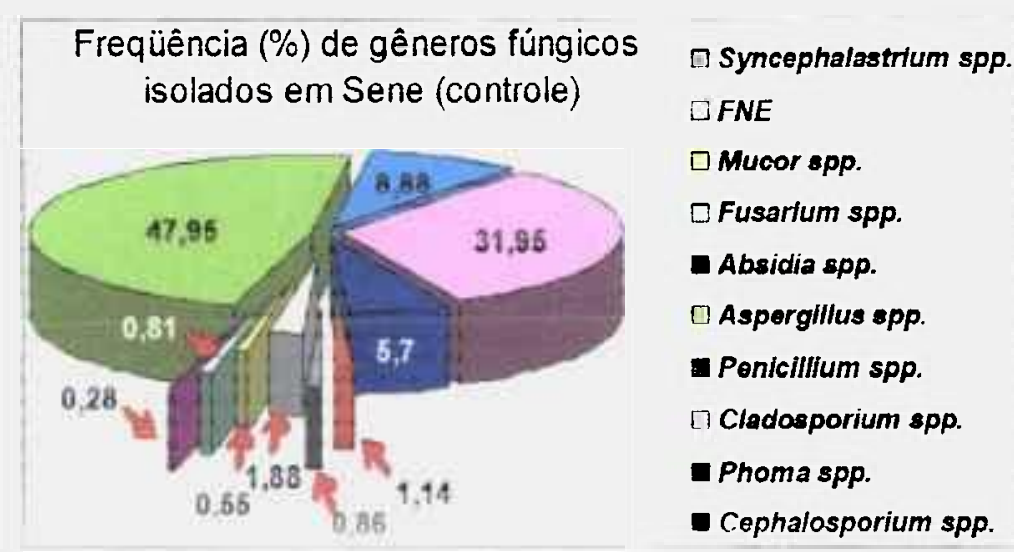

FIGURA 41. Freqüência de gêneros de fungos isolados em amostras de Sene (não irradiadas). 
Do gênero Aspergillus. as espécies isoladas foram. $46 \%$ de A. niger: $33 \%$ de A. amstelodami; $17 \%$ de $A$. flavus: $1.3 \%$ de A. fumigatus: $0,6 \%$ de $A$. restrictus; $0,5 \%$ de A parasiticus; $0,2 \%$ de $A$. penicillioides e $0,18 \%$ de A. glaucus (FIG.42).

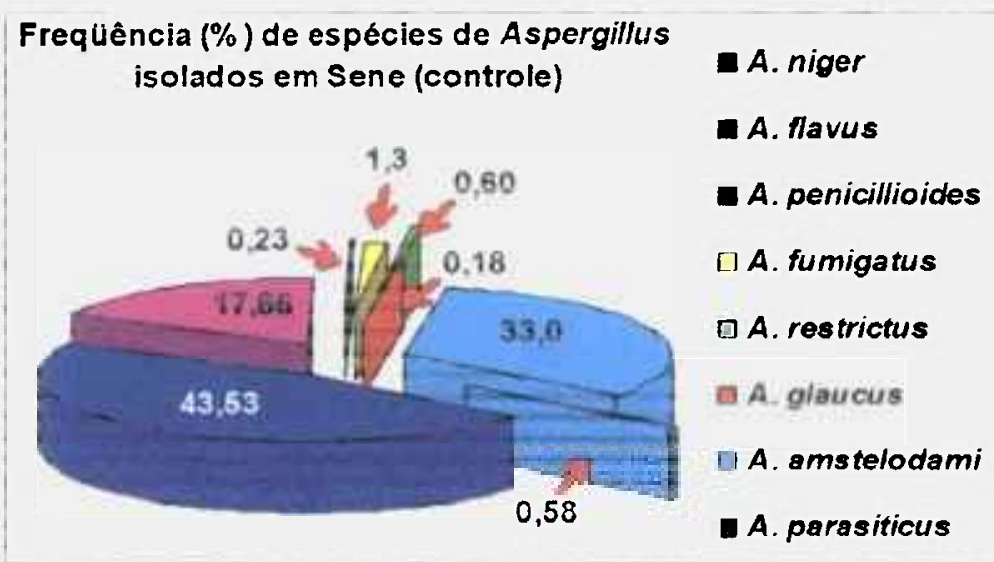

FIGURA 42. Freqüência de espécies de Aspergillus isolados em amostras de Sene (não irradiadas)

O grupo controle de Guaraná apresentou a freqüência de gêneros fúngicos na ordem de $76 \%$ de Aspergillus; $10 \%$ de Penicillium; $10 \%$ de Cladosporium e $3,5 \%$ de Cephalosporium (FIG. 43) e a freqüência das espécies isoladas, do gênero Aspergillus, foram: $53 \%$ de $A$. niger; $13 \%$ de $A$. flavus; $9 \%$ de A. restrictus: $0,7 \%$ de $A$. penicillioides e $0,6 \%$ de $A$. ochraceus (FIG. 44).

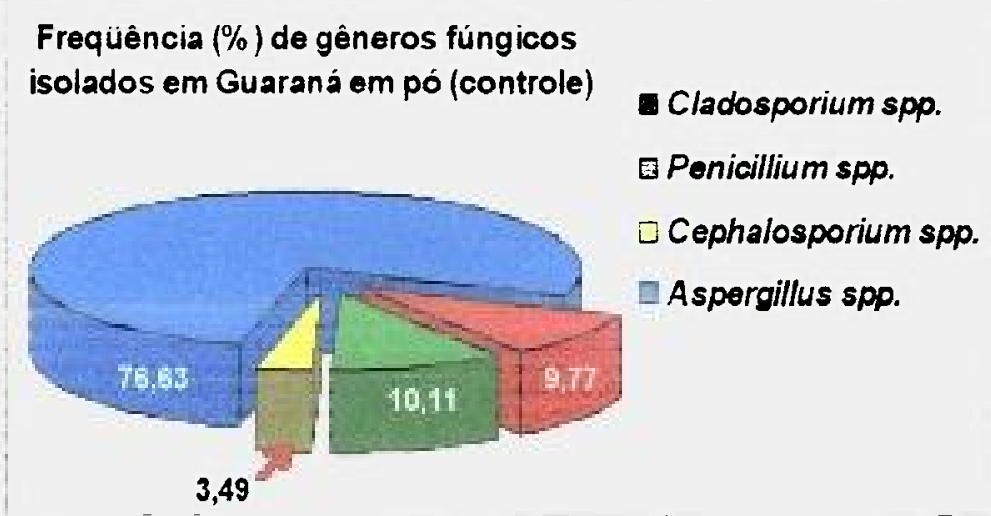

FIGURA 43. Freqüência de gêneros de fungos isolados em Guaraná em pó (não irradiado). 


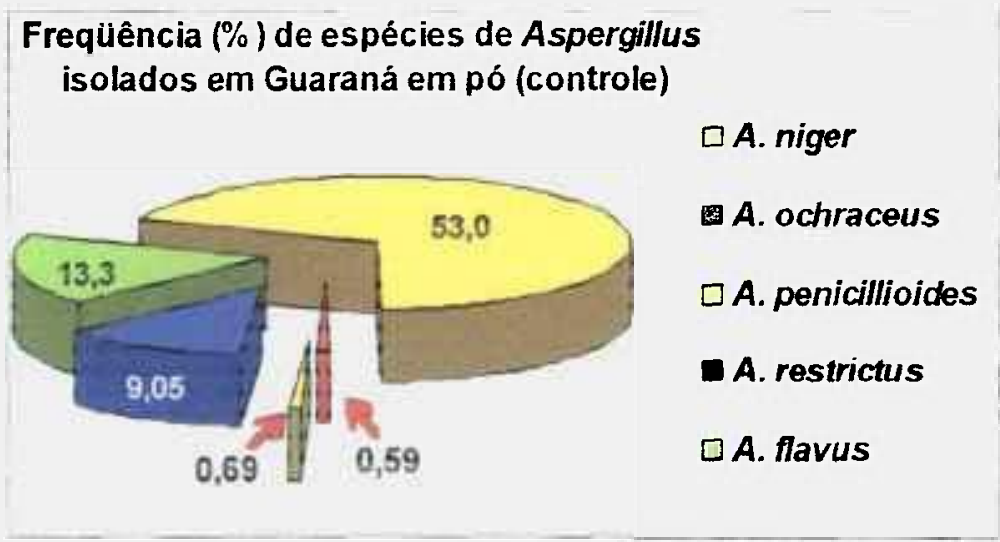

FIGURA 44. Freqüência de espécies de Aspergillus isolados em amostras de Guaraná (não irradiadas).

O grupo controle de Chá verde apresentou a freqüência de gêneros isolados de $54 \%$ de Aspergillus; $24 \%$ de Syncephalastrum; $18 \%$ de Penicillium e $2 \%$ de FNE (FIG.45), observando-se que a freqüência das espécies isoladas do gênero Aspergillus, no total de amostras, foi: $76 \%$ de $A$. niger; $17 \%$ de $A$. flavus e $6 \%$ de $A$. wentii (FIG 46).

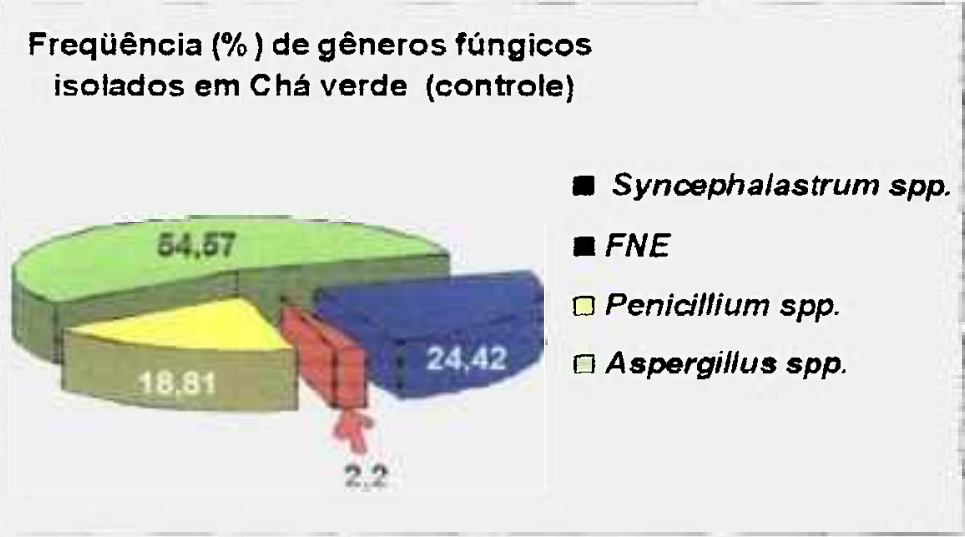

FIGURA 45. Freqüência de gêneros de fungos isolados em Chá verde (não irradiado). 
Em relação aos produtos adquiridos em farmácia ou lojas de produtos naturais (embalados ou em potes), foram encontrados os valores de $100 \%$ (E. santa); $86 \%$ (Boldo); $100 \%$ (Sene); $71 \%$ (Guaraná) e $57 \%$ (Chá-verde).

Nas amostras analisadas coletadas em feiras livres (com exposição aberta em sacarias ou embaladas das plantas medicinais), a freqüência de amostras acima dos limites foi igualmente de $85 \%$ para Espinheira santa, Boldo, Guaraná e Chá verde, enquanto Sene apresentou $100 \%$ das amostras acima dos limites, conforme ilustra a FIG.47. 


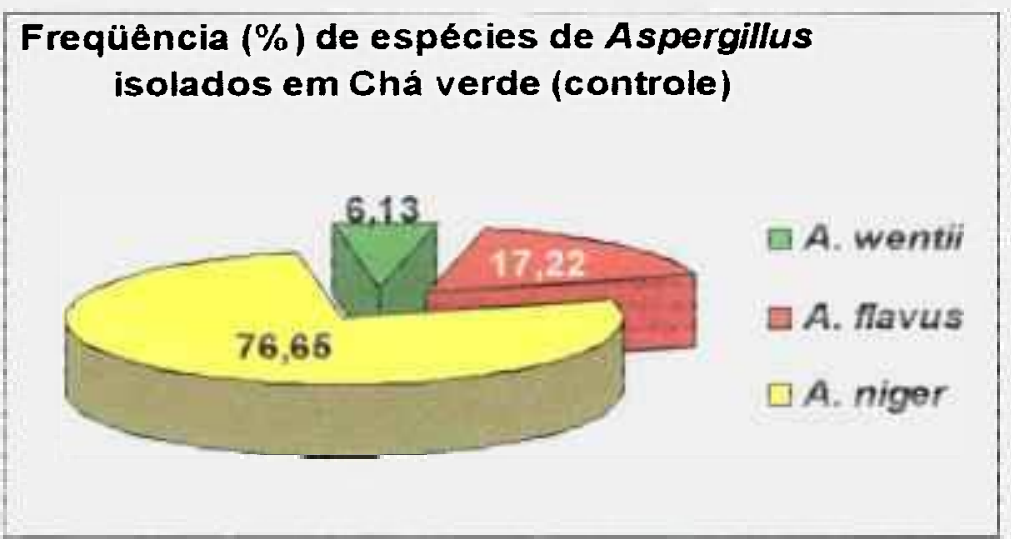

FIGURA 46. Frequiência de espécies de Aspergillus isolados em amostras de Chá verde (não irradiado).

\subsection{Freqüência (\%) da contaminação füngica por locais de venda}

As amostras de Espinheira santa, Boldo, Sene, Guaraná e Chá verde, coletadas no mercado atacadista, apresentaram valores de $50 \%, 16 \% ; 83 \%, 100 \%$ e $33 \%$ respectivamente, dos valores considerados acima dos limites preconizados pela OMS $\left(1,0 \times 10^{3} \mathrm{UFC/g}\right)$ 


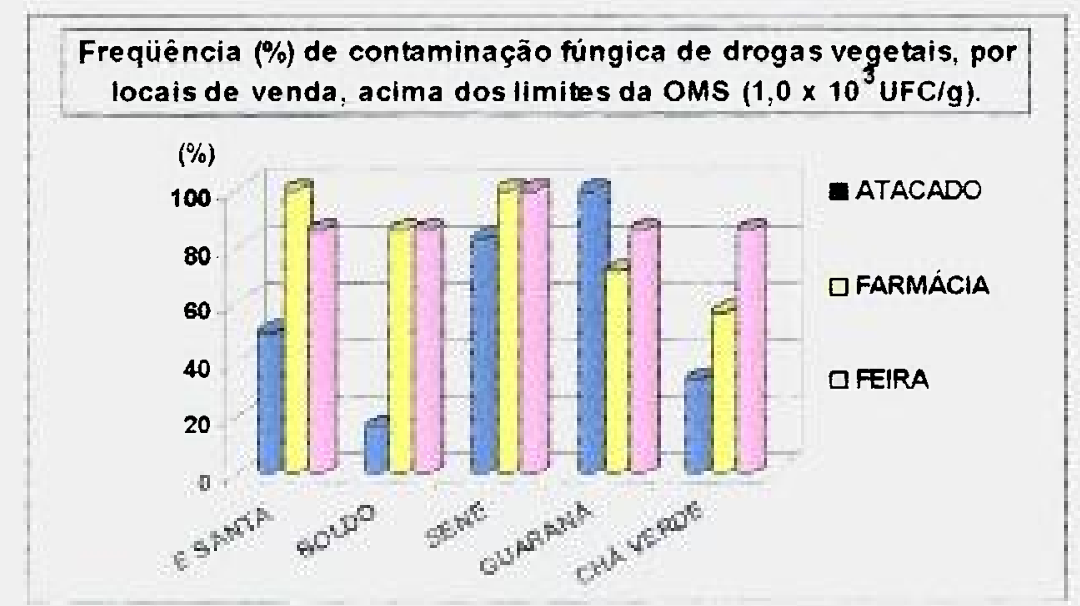

FIGURA 47. Comparação da contaminação fúngica de plantas medicinais de acordo com a forma de comercialização.

\subsection{Pesquisa da microbiota fúngica (amostras irradiadas).}

Do total de amostras dos grupos controles de Boldo, Espinheira santa, Sene, Guaraná em pó e Chá verde, a freqüência (\%) de amostras contaminadas por fungos foi de $85 \%, 100 \%, 100 \%, 100 \%$ e $90 \%$, respectivamente.

A contaminação fúngica das amostras de Boldo, tratadas pelo processo de irradiação, com a dose de 5 kGy no dia 0 , foi de $15 \%$ e após 30 dias de $10 \%$ (TAB. 3). O fungo que apresentou crescimento em todas as placas, após os tratamentos, foi A. flavus.

Em relação às amostras de Espinheira santa foi de $15 \%$ e $30 \%$ nos dias 0 e 30 dias, respectivamente, conforme demonstrado na TAB. 4. A flavus foi o fungo que apresentou resistência após os tratamentos. Quanto ao Sene. no dia 0 e 30 dias após o tratamento, observou-se que $25 \%$ e $30 \%$ das amostras tratadas com a dose de 5 kGy (FIG. 48), apresentaram crescimento fúngico, respectivamente (TAB. 5). Phoma spp. (20\%) em Sene (FIG. 49), nos dois periodos de tratamento. A. niger (5\%), no dia 0 e após 30 dias $10 \%$ de A. flavus (FIG. 50). 
A análise da contaminação fúngica de Guaraná demonstrou $5 \%$ de isolados do gênero Phoma, nas amostras do dia 0 e manteve-se após 30 dias (TAB.6) O total de isolados fúngicos nas amostras de Chá-verde, nos dias 0 e $30^{\circ}$, mostraram a freqüência de $15 \%$ e $5 \%$, respectivamente (TAB. 7), com $5 \%$ de A. niger (FIG. 51) e $10 \%$ de Syncephalastrum spp. (FIG. 52 e 53) no dia 0, enquanto que no $30^{\circ}$ dia, observou-se 5\% de Syncephalastrum spp. (FIG.54 e 55). Em relação ao tratamento com $10 \mathrm{kGy}$, as amostras de Boldo, Guaraná em pó e Chá-verde apresentaram completa eliminação da contaminação inicial, com exceção do Sene, onde 5\% representou a microbiota fúngica presente nas amostras analisadas no mesmo dia do tratamento (dia 0) pela radiação ionizante (FIG. 48)

Nas amostras de Boldo, Espinheira santa, Guaraná em pó e Chá verde, irradiadas com a dose de $10 \mathrm{kGy}$, a completa descontaminação foi efetiva, logo após o tratamento pela radiação ionizante das drogas vegetais, como manteve a esterilidade do material embalado, após 30 dias do processo de irradiação (TAB. 8, 9,11 e 12). Foi observado o crescimento de fungos em $5 \%$ das amostras de Sene (Phoma spp.), logo após o tratamento por radiação ionizante, no entanto, o fungo não foi isolado nas amostras analisadas após 30 dias do tratamento (TAB. 10).

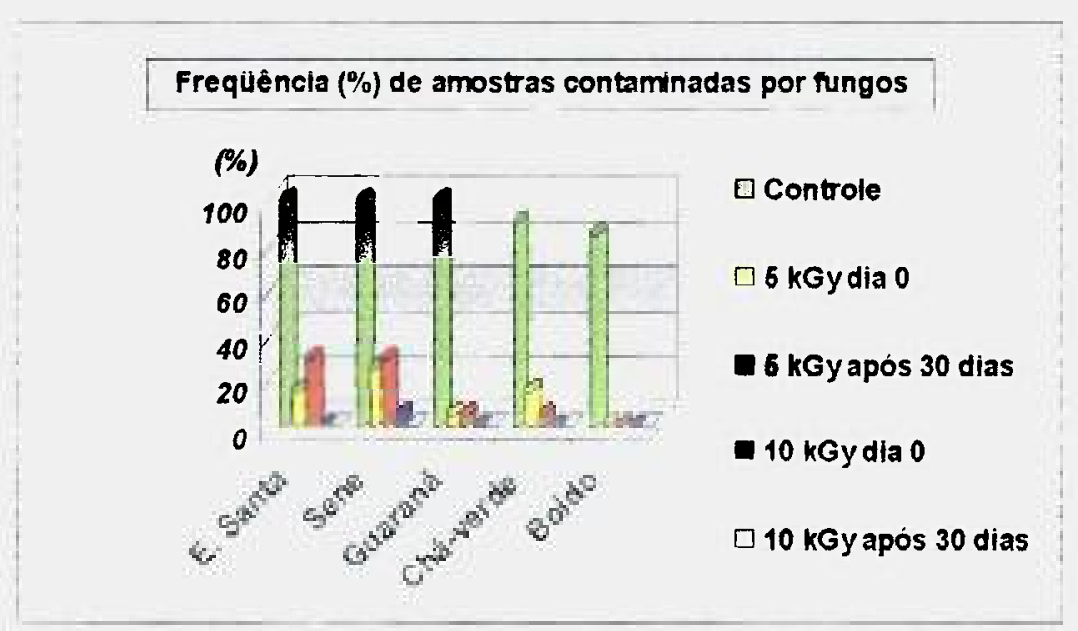

FIGURA 48. Freqüiência de fungos da amostras controles e irradiadas no dia 0 e após 30 dias. 


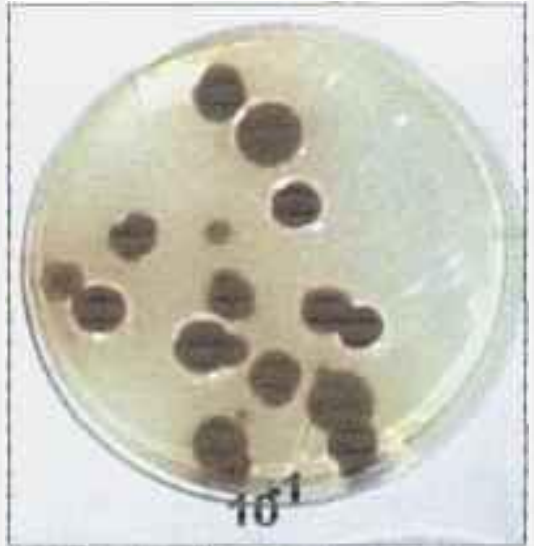

FIGURA 49. Phoma spp. em Sene (5 kGy)

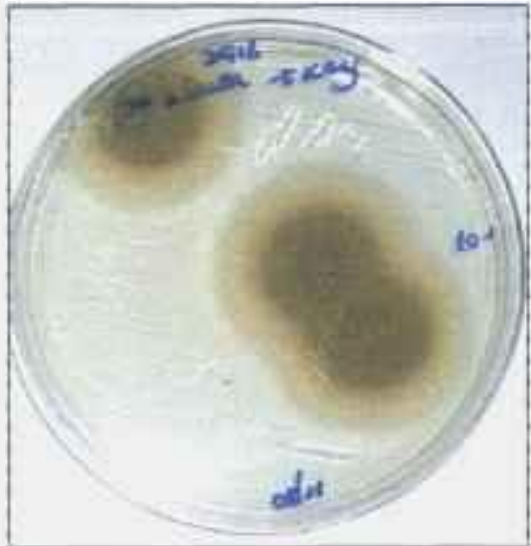

FIGURA 50. Aspergillus spp. em Sene (5kGy).

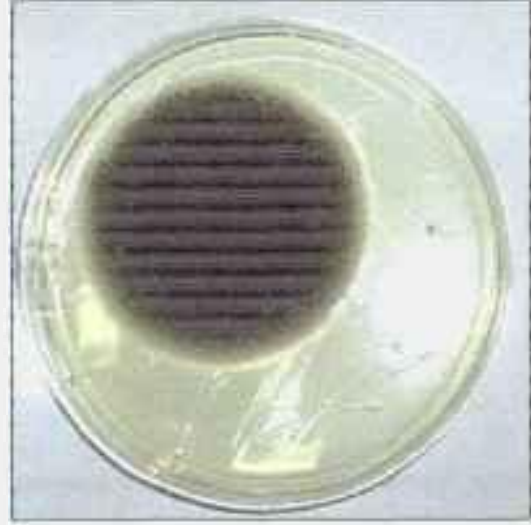

FIGURA 51. Colônia de A. niger.

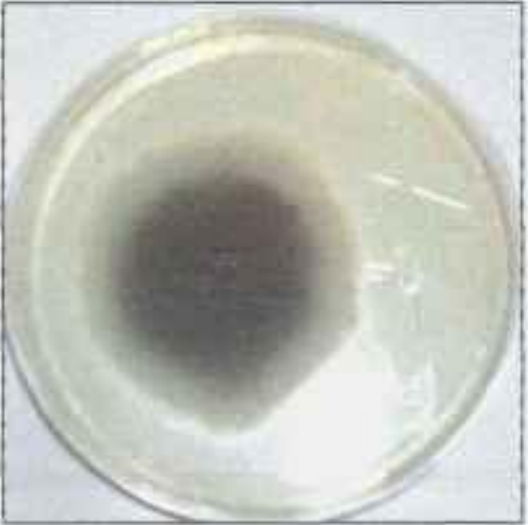

FIGURA 52. Colônia de Syncephalastrum spp.

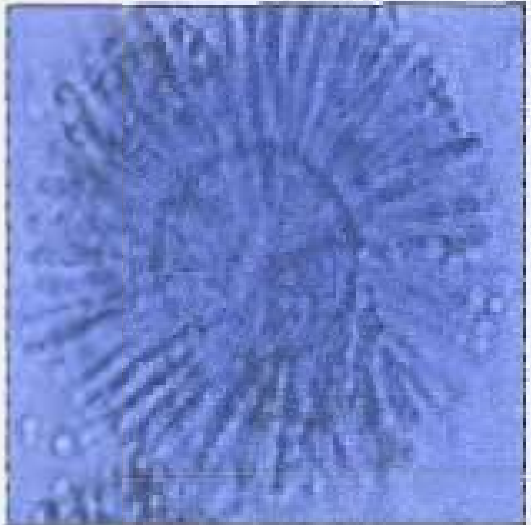

FIGURA 53. Syncephalastrum spp radiação gama (dia 0) na dose de 6 kGy

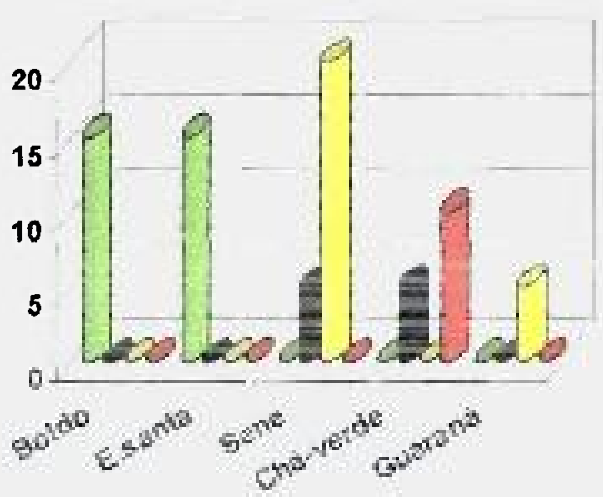

$\square$ A. flavus

A. niger

口Phoma spp.

a Syncephalastrum spp.

FIGURA 54. Gêneros fúngicos isolados em drogas vegetais após o tratamento com a dose de $5 \mathrm{kGy}$ (dia 0). 


$$
\text { 柾 }
$$


TABELA 3. Contagens de fungos isoladoe (UFCly) das amostres do grupo conthe (n⿳⺈冂大 irradiadas) e irradiadas com a dose de 5 KGy analisedas no dia 0 e aps 32 dias de Boldio.

Anoctras Controle ${ }^{a}$ Madiadas dia $0^{b}$ imradiadas após 30 dias $^{3}$

\begin{tabular}{cccc}
\hline 1 & 0 & 0 & 0 \\
2 & $5,0 \times 10^{2}$ & $0,5 \times 10^{2}$ & 0 \\
3 & 0 & 0 & 0 \\
4 & $2,0 \times 10^{2}$ & $0,5 \times 10^{2}$ & 0 \\
5 & $1,5 \times 10^{2}$ & 0 & 0 \\
6 & $1,6 \times 10^{6}$ & $0,5 \times 10^{2}$ & $1,0 \times 10^{2} \square$ \\
7 & $1,1 \times 10^{3}$ & 0 & 0 \\
8 & $1,5 \times 10^{4}$ & 0 & 0 \\
9 & $1,1 \times 10^{3}$ & 0 & 0 \\
10 & $2,5 \times 10^{3}$ & 0 & 0 \\
11 & $2,8 \times 10^{2}$ & 0 & 0 \\
12 & $3,0 \times 10^{3}$ & 0 & 0 \\
13 & $4,0 \times 10^{3}$ & 0 & 0 \\
14 & 0 & 0 & 0 \\
15 & $1,1 \times 10^{4}$ & 0 & 0 \\
16 & $2,3 \times 10^{3}$ & 0 & 0 \\
17 & $7,0 \times 10^{3}$ & 0 & 0 \\
18 & $2,5 \times 10^{3}$ & 0 & 0 \\
19 & $5,5 \times 10^{5}$ & 0 & $0,5 \times 10^{2} \square$ \\
20 & $2,2 \times 10^{5}$ & 0 & 0 \\
\hline
\end{tabular}

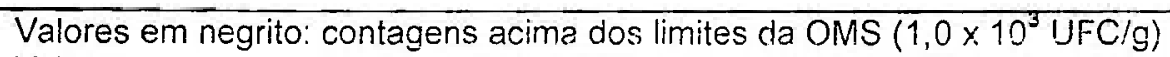

Valores comparados entre ab e ac: $p<0,001$ (diferença significante)

Valores comparados entre bc: $p>0,05$ (não significante)

$\square$ A. flavus 
TABELA 4. Contagens de fugos isolados (UFCIO) das amostas do grupo controle (näo irreciadas) e iradiadas con c dose de $5 \mathrm{kGy}$ analisadas no dia 0 e a pós 30 dias de spinheira santa.

Amostras Conerola ${ }^{a}$ Iradiadas dia $0^{\circ}$ lradpdas apos 30 das ${ }^{\circ}$

$\begin{array}{cccc}1 & 6,0 \times 10^{2} & 0 & 0 \\ 2 & 1,8 \times 10^{3} & 0,5 \times 10^{2} \square & 1,0 \times 10^{2} \square \\ 3 & 7,0 \times 10^{2} & 0 & 0 \\ 4 & 1,6 \times 10^{3} & 0 & 0 \\ 5 & 5,0 \times 10^{2} & 0 & 0,5 \times 10^{2} \square \\ 6 & 3,8 \times 10^{4} & 0,5 \times 10^{2} \square & 0 \\ 7 & 2,0 \times 10^{3} & 0 & 1,0 \times 10^{1} \square \\ 8 & 1,2 \times 10^{4} & 0 & 0 \\ 9 & 3,5 \times 10^{3} & 0 & 0 \\ 10 & 1,4 \times 10^{4} & 0 & 0,5 \times 10^{2} \square \\ 11 & 3,5 \times 10^{4} & 0 & 0 \\ 12 & 4,5 \times 10^{3} & 0 & 5,0 \times 10^{2} \square \\ 13 & 1,3 \times 10^{4} & 1,0 \times 10^{2} \square & 0 \\ 14 & 3,1 \times 10^{4} & 0 & 0 \\ 15 & 1,5 \times 10^{3} & 0 & 0 \\ 16 & 1,3 \times 10^{3} & 0 & 0 \\ 17 & 8,5 \times 10^{3} & 0 & 0 \\ 18 & 6,0 \times 10^{3} & 0 & 0 \\ 19 & 1,5 \times 10^{2} & 0 & 0 \\ 20 & 1,2 \times 10^{3} & 0 & 0\end{array}$

Valores E:Ti necrito. contagens ecima cos limites de onis $\left[1,0 \times 10^{x}\right.$ UFCigj)

Valores comparados entre $a b$ e ac: $p<0,001$ (diferença significante)

Valores comparados entre bc: $p>0,05$ (não significante)

$\square$ A. flavus 
TABELA 5. Contagens de fungos isolados (UFC/g) das amostras do grupo controle (não imaladas) e irradiadas con a dose de 5 kCy analisadas no dia 0 e após 30 dias de sene.

Amostias Controla ${ }^{a} \quad$ Iradiadas dia $0^{b}$ Iradiadas após 30 diasc

$\begin{array}{cccc}1 & 2,3 \times 10^{3} & 1,0 \times 10^{2} \diamond & 0,4 \times 10^{2} 。 \\ 2 & 5,1 \times 10^{3} & 0,5 \times 10^{2} \circ & 0 \\ 3 & 1,7 \times 10^{3} & 0,5 \times 10^{2} \circ & 0,5 \times 10^{2} \circ \\ 4 & 1,5 \times 10^{3} & 0,5 \times 10^{2} \circ & 1,0 \times 10^{2} \\ 5 & 7,0 \times 10^{2} & 0 & 0 \\ 6 & 1,8 \times 10^{3} & 0 & 3,5 \times 10^{2} \square \\ 7 & 5,6 \times 10^{4} & 0 & 6,0 \times 10^{2} \\ 8 & 1,3 \times 10^{5} & 0 & 0 \\ 9 & 1,5 \times 10^{4} & 0 & 0 \\ 10 & 6,3 \times 10^{4} & 0 & 0 \\ 11 & 6,3 \times 10^{3} & 0 & 0 \\ 12 & 2,5 \times 10^{5} & 0 & 0 \\ 13 & 2,0 \times 10^{3} & 1,0 \times 10^{2} \circ & 2,0 \times 10^{2} \\ 14 & 1,6 \times 10^{4} & 0 & 0 \\ 15 & 3,0 \times 10^{3} & 0 & 0 \\ 16 & 1,8 \times 10^{3} & 0 & 0 \\ 17 & 5,6 \times 10^{4} & 0 & 0 \\ 18 & 1,3 \times 10^{5} & 0 & 0 \\ 19 & 5,0 \times 10^{5} & 0 & 0 \\ 20 & 3,0 \times 10^{4} & 0 & 0\end{array}$

Valores em negrito: contagens acima dos limites da OMS (1,0 × $\left.10^{5} \mathrm{UFC} / \mathrm{g}\right)$

Valores comparados entre ab e ac: $p<0,001$ (diferença significante)

Valores comparados entre bc: $p>0,05$ (não significante)

$\checkmark$ A. niger; ० Phoma spp.; $\square$ A. flavus 
TABELA G. Contagens de fungos isoledos (UFC/g) das amostras dio grupo controle (näo hirdiadas) e irradiacias com a duse de $5 k G y$ analisadas no dia 0 e apćs 30 dias de Cuaraná em pó.

\begin{tabular}{|c|c|c|c|}
\hline Amostres & Controle ${ }^{a}$ & Irradiadas dia $0^{b}$ & Mradiadas após 30 dias ${ }^{c}$ \\
\hline 1 & $2,0 \times 10^{4}$ & 0 & 0 \\
\hline 2 & $8,0 \times 10^{4}$ & 0 & 0 \\
\hline 3 & $2,1 \times 10^{5}$ & 0 & 0 \\
\hline 4 & $2,8 \times 10^{4}$ & 0 & 0 \\
\hline 5 & $1,1 \times 10^{4}$ & 0 & 0 \\
\hline 6 & $2,1 \times 10^{5}$ & 0 & 0 \\
\hline 7 & $4,2 \times 10^{5}$ & 0 & 0 \\
\hline 8 & $1,3 \times 10^{5}$ & 0 & 0 \\
\hline 9 & $5,0 \times 10^{2}$ & 0 & 0 \\
\hline 10 & $6,3 \times 10^{4}$ & 0 & 0 \\
\hline 11 & $2,0 \times 10^{5}$ & 0 & 0 \\
\hline 12 & $0,5 \times 10^{2}$ & 0 & 0 \\
\hline 13 & $1,8 \times 10^{5}$ & 0 & 0 \\
\hline 14 & $2,1 \times 10^{6}$ & 0 & 0 \\
\hline 15 & $1,5 \times 10^{4}$ & $0,5 \times 10^{2}$ & $1,0 \times 10^{2}$ \\
\hline 16 & $5,0 \times 10^{2}$ & 0 & 0 \\
\hline 17 & $1,2 \times 10^{5}$ & 0 & 0 \\
\hline 18 & $1,0 \times 10^{6}$ & 0 & 0 \\
\hline 19 & $2,0 \times 10^{5}$ & 0 & 0 \\
\hline 20 & $9,0 \times 10^{5}$ & 0 & 0 \\
\hline
\end{tabular}

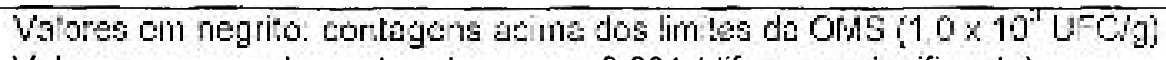

Valores comparados entre ab e ac: $p<0,001$ (diferença significante)

Valores comparados entre bc: $p>0,05$ (não significante)

- Phoma spp. 
TABEIA 7. Contagens de fungos isolados (UFC/g) das amostras cio grupo controle (não irradiadas) e irradiadas com a dose de 5 kGy analisadas no dia o e apos 30 dias de Chá verde.

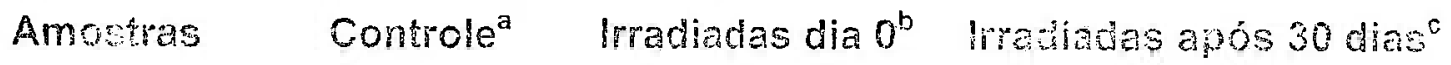

\begin{tabular}{|c|c|c|c|}
\hline 1 & $3,0 \times 10^{2}$ & $0,5 \times 10^{2} \nabla$ & 0 \\
\hline 2 & $1,5 \times 10^{2}$ & 0 & 0 \\
\hline 3 & 0 & $1,0 \times 10^{2} 0$ & 0 \\
\hline 4 & $2,5 \times 10^{3}$ & 0 & 0 \\
\hline 5 & 0 & 0 & 0 \\
\hline 6 & $1,1 \times 10^{4}$ & 0 & 0 \\
\hline 7 & $1,0 \times 10^{4}$ & 0 & 0 \\
\hline 8 & $1,0 \times 10^{3}$ & 0 & 0 \\
\hline 9 & $5,0 \times 10^{3}$ & $5,0 \times 10^{2} \nabla$ & $0,5 \times 10^{2} \nabla$ \\
\hline 10 & $1,0 \times 10^{2}$ & 0 & 0 \\
\hline 11 & $1,1 \times 10^{3}$ & 0 & 0 \\
\hline 12 & $2,0 \times 10^{3}$ & 0 & 0 \\
\hline 13 & $1,0 \times 10^{2}$ & 0 & 0 \\
\hline 14 & $1,0 \times 10^{3}$ & 0 & 0 \\
\hline 15 & $2,0 \times 10^{3}$ & 0 & 0 \\
\hline 16 & $6,0 \times 10^{3}$ & 0 & 0 \\
\hline 17 & $1,5 \times 10^{4}$ & 0 & 0 \\
\hline 18 & $7,5 \times 10^{3}$ & 0 & 0 \\
\hline 19 & $6,0 \times 10^{3}$ & 0 & 0 \\
\hline 20 & $1,0 \times 10^{4}$ & 0 & 0 \\
\hline
\end{tabular}


TAEEL.A 8. Contagens de fungos isolados (UFC/g) das amostras do grupo controle (não irradiades) e irradiadas com a dose de $10 \mathrm{kGy}$ analisadas no dia 0 e após 30 dias de soldo.

\begin{tabular}{cccc} 
Amostras & Controle & Irradiarlas dia $0^{b}$ & Irradiadas após 30 dias $^{c}$ \\
\hline 1 & 0 & 0 & 0 \\
2 & $5,0 \times 10^{2}$ & 0 & 0 \\
3 & 0 & 0 & 0 \\
4 & $2,0 \times 10^{2}$ & 0 & 0 \\
5 & $1,5 \times 10^{2}$ & 0 & 0 \\
6 & $1,6 \times 10^{6}$ & 0 & 0 \\
7 & $1,1 \times 10^{3}$ & 0 & 0 \\
8 & $1,5 \times 10^{4}$ & 0 & 0 \\
9 & $1,1 \times 10^{3}$ & 0 & 0 \\
10 & $2,5 \times 10^{3}$ & 0 & 0 \\
11 & $2,8 \times 10^{2}$ & 0 & 0 \\
12 & $3,0 \times 10^{3}$ & 0 & 0 \\
13 & $4,0 \times 10^{3}$ & 0 & 0 \\
14 & 0 & 0 & 0 \\
15 & $1,1 \times 10^{4}$ & 0 & 0 \\
16 & $2,3 \times 10^{3}$ & 0 & 0 \\
17 & $7,0 \times 10^{3}$ & 0 & 0 \\
18 & $2,5 \times 10^{3}$ & 0 & 0 \\
19 & $5,5 \times 10^{5}$ & 0 & 0 \\
20 & $2,2 \times 10^{5}$ & 0 & 0 \\
\hline & 2,19 & 0
\end{tabular}

Valores em negrito: contagens acima dos limites da OMS $\left(1,0 \times 10^{3} \mathrm{UFC} / \mathrm{g}\right)$

Valores comparados entre ab e ac: $p<0,001$ (diferença significante)

Valores comparados entre bc: $p>0,05$ (não significante) 
TABE A 9. Contagens de fungos isolados (UFC/g) das amostras do gripo controie (não irradiadas) e irradiadas com a dose de $10 \mathrm{kGy}$ analisadas no dia 0 e após 30 dias de Espinheira santa.

Amostras Controle ${ }^{a} \quad$ Irradiadas dia $0^{b}$ Imadiadas após 30 dies ${ }^{c}$

\begin{tabular}{|c|c|c|c|}
\hline 1 & $6,0 \times 10^{2}$ & 0 & 0 \\
\hline 2 & $1,8 \times 10^{3}$ & 0 & 0 \\
\hline 3 & $7,0 \times 10^{2}$ & 0 & 0 \\
\hline 4 & $1,6 \times 10^{3}$ & 0 & 0 \\
\hline 5 & $5,0 \times 10^{2}$ & 0 & 0 \\
\hline 6 & $3,8 \times 10^{4}$ & 0 & 0 \\
\hline 7 & $2,0 \times 10^{3}$ & 0 & 0 \\
\hline 8 & $1,2 \times 10^{4}$ & 0 & 0 \\
\hline 9 & $3,5 \times 10^{3}$ & 0 & 0 \\
\hline 10 & $1,4 \times 10^{4}$ & 0 & 0 \\
\hline 11 & $3,5 \times 10^{4}$ & 0 & 0 \\
\hline 12 & $4,5 \times 10^{3}$ & 0 & 0 \\
\hline 13 & $1,3 \times 10^{4}$ & 0 & 0 \\
\hline 14 & $3,1 \times 10^{4}$ & 0 & 0 \\
\hline 15 & $1,5 \times 10^{3}$ & 0 & 0 \\
\hline 16 & $1,3 \times 10^{3}$ & 0 & 0 \\
\hline 17 & $8,5 \times 10^{3}$ & 0 & 0 \\
\hline 18 & $6,0 \times 10^{3}$ & 0 & 0 \\
\hline 19 & $1,5 \times 10^{2}$ & 0 & 0 \\
\hline 20 & $1,2 \times 10^{3}$ & 0 & 0 \\
\hline
\end{tabular}

Valores em negrito: contegens acima dos limites da OMS $(1,0 \times 10$ UFCig)

Valores comparados entre ab e ac: $p<0,001$ (diferença significante)

Valores comparados entre bc: $p>0,05$ (não significante) 
TABELA 10. Contagens de fungos isolados (UFC/g) das amostras do grupo controle (não irradiadas) e irradiadas com a dose de $10 \mathrm{kGy}$ arialisadas no dia 0 e após 30 dias de Sene.

Amostras Controle ${ }^{a} \quad$ Irradiadas dia $0^{b}$ Irradiadas após 30 dias $^{c}$

$\begin{array}{llll}1 & 2,3 \times 10^{3} & 0 & 0 \\ 2 & 5,1 \times 10^{3} & 0 & 0 \\ 3 & 1,7 \times 10^{3} & 0 & 0 \\ 4 & 1,5 \times 10^{3} & 0 & 0 \\ 5 & 7,0 \times 10^{2} & 0 & 0 \\ 6 & 1,8 \times 10^{3} & 0 & 0 \\ 7 & 5,6 \times 10^{4} & 0 & 0 \\ 8 & 1,3 \times 10^{5} & 0 & 0 \\ 9 & 1,5 \times 10^{4} & 0 & 0 \\ 10 & 6,3 \times 10^{4} & 0 & 0 \\ 11 & 6,3 \times 10^{3} & 0 & 0 \\ 12 & 2,5 \times 10^{5} & 0 & 0 \\ 13 & 2,0 \times 10^{3} & 1,1 \times 10^{3} & 0 \\ 14 & 1,6 \times 10^{4} & 0 & 0 \\ 15 & 3,0 \times 10^{3} & 0 & 0 \\ 16 & 1,8 \times 10^{3} & 0 & 0 \\ 17 & 5,6 \times 10^{4} & 0 & 0 \\ 18 & 1,3 \times 10^{5} & 0 & 0 \\ 19 & 5,0 \times 10^{5} & 0 & 0 \\ 20 & 3,0 \times 10^{4} & 0 & 0\end{array}$

Valores em negrito: contagens acima dos limites da OMS $\left(1,0 \times 10^{3}\right.$ UFC' $\left.\overline{F^{\prime}}\right)$

Valores comparados entre ab e ac: $p<0,001$ (diferença significante)

Valores comparados entre bc: $p>0,05$ (não significante)

- Phoma spp. 
TABELA 11. Contagens de fungos isolados (UFC/g) das amostras do grupo controle (não irradiadas) e irradiadas com a dose de $10 \mathrm{kGy}$ analisadas no dia 0 e apćs 30 dias do Guaraná smi pó.

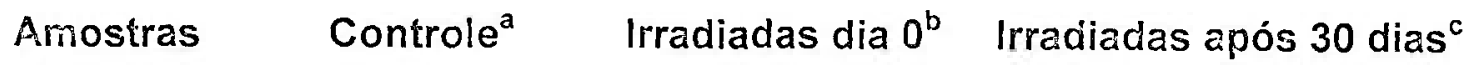

\begin{tabular}{|c|c|c|c|}
\hline 1 & $2,0 \times 10^{4}$ & 0 & 0 \\
\hline 2 & $8,0 \times 10^{4}$ & 0 & 0 \\
\hline 3 & $2,1 \times 10^{5}$ & 0 & 0 \\
\hline 4 & $2,8 \times 10^{4}$ & 0 & 0 \\
\hline 5 & $1,1 \times 10^{4}$ & 0 & 0 \\
\hline 6 & $2,4 \times 10^{5}$ & 0 & 0 \\
\hline 7 & $4,2 \times 10^{5}$ & 0 & 0 \\
\hline 8 & $1,3 \times 10^{5}$ & 0 & 0 \\
\hline 9 & $5,0 \times 10^{2}$ & 0 & 0 \\
\hline 10 & $6,3 \times 10^{4}$ & 0 & 0 \\
\hline 11 & $2,0 \times 10^{5}$ & 0 & 0 \\
\hline 12 & $0,5 \times 10^{2}$ & 0 & 0 \\
\hline 13 & $1,3 \times 10^{5}$ & 0 & 0 \\
\hline 14 & $2,1:: 10^{6}$ & 0 & 0 \\
\hline 15 & $1,5 \times 10^{4}$ & 0 & 0 \\
\hline 16 & $5,0 \times 10^{2}$ & 0 & $\mathrm{C}$ \\
\hline 17 & $1, \because: 310^{5}$ & 0 & (! \\
\hline 10 & $5: 0: 10^{6}$ & 0 & 0 \\
\hline $1 !$ & $\because=10^{5}$ & 0 & 0 \\
\hline$\cdots$ & $\because: a n^{5}$ & 9 & ' \\
\hline
\end{tabular}


TABELA 12. Contagens de fungos isolados (UFC/g) das amostras do grupo controle (não irradiadas) e irradiadas com a dose de $10 \mathrm{kGy}$ analisadas no dia $0 \mathrm{e}$ após 30 dias de Chá verde.

Amostras Controle $^{\mathrm{a}} \quad$ Irradiadas dia $0^{\mathrm{b}} \quad$ Irradiadas após 30 dias $^{\mathrm{c}}$

$\begin{array}{cccc}1 & 3,0 \times 10^{2} & 0 & 0 \\ 2 & 1,5 \times 10^{2} & 0 & 0 \\ 3 & 0 & 0 & 0 \\ 4 & 2,5 \times 10^{3} & 0 & 0 \\ 5 & 0 & 0 & 0 \\ 6 & 1,1 \times 10^{4} & 0 & 0 \\ 7 & 1,0 \times 10^{4} & 0 & 0 \\ 8 & 1,0 \times 10^{3} & 0 & 0 \\ 9 & 5,0 \times 10^{3} & 0 & 0 \\ 10 & 1,0 \times 10^{2} & 0 & 0 \\ 11 & 1,1 \times 10^{3} & 0 & 0 \\ 12 & 2,0 \times 10^{3} & 0 & 0 \\ 13 & 1,0 \times 10^{2} & 0 & 0 \\ 14 & 1,0 \times 10^{3} & 0 & 0 \\ 15 & 2,0 \times 10^{3} & 0 & 0 \\ 16 & 6,0 \times 10^{3} & 0 & 0 \\ 17 & 1,5 \times 10^{4} & 0 & 0 \\ 13 & 7,5 \times 10^{3} & 0 & 0 \\ 19 & 6,0 \times 10^{3} & 0 & 0 \\ 20 & 1,0 \times 10^{4} & 0 & 0\end{array}$

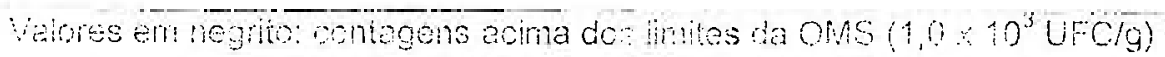

Valores comparados enite ab e ac: $p<0,6$ : a (diferenga sionifionite)

Valores cunparados enire bo: $p>0,05$ (nङio significante) 
A análise de variância ANOVA e o Teste de múltipla comparação de TukeyKramer demonstraram que as amostras de todas as drogas vegetais (Sene, Espinheira santa, Boldo, Chá verde e Guaraná) do grupo controle ( $0 \mathrm{kGy}$ ), em relação às amostras tratadas com as doses de 5 e $10 \mathrm{kGy}$ apresentaram uma diferença significante entre os valores encontrados em UFC/g $(p<0,001)$. Entretanto, comparando-se as amostras irradiadas com 5 e $10 \mathrm{kGy}$ (tanto no dia 0 e 30 dias), a diferença nas contagens de UFC/g foi considerada não significante $(p>0,05)$ (FIG. 56).

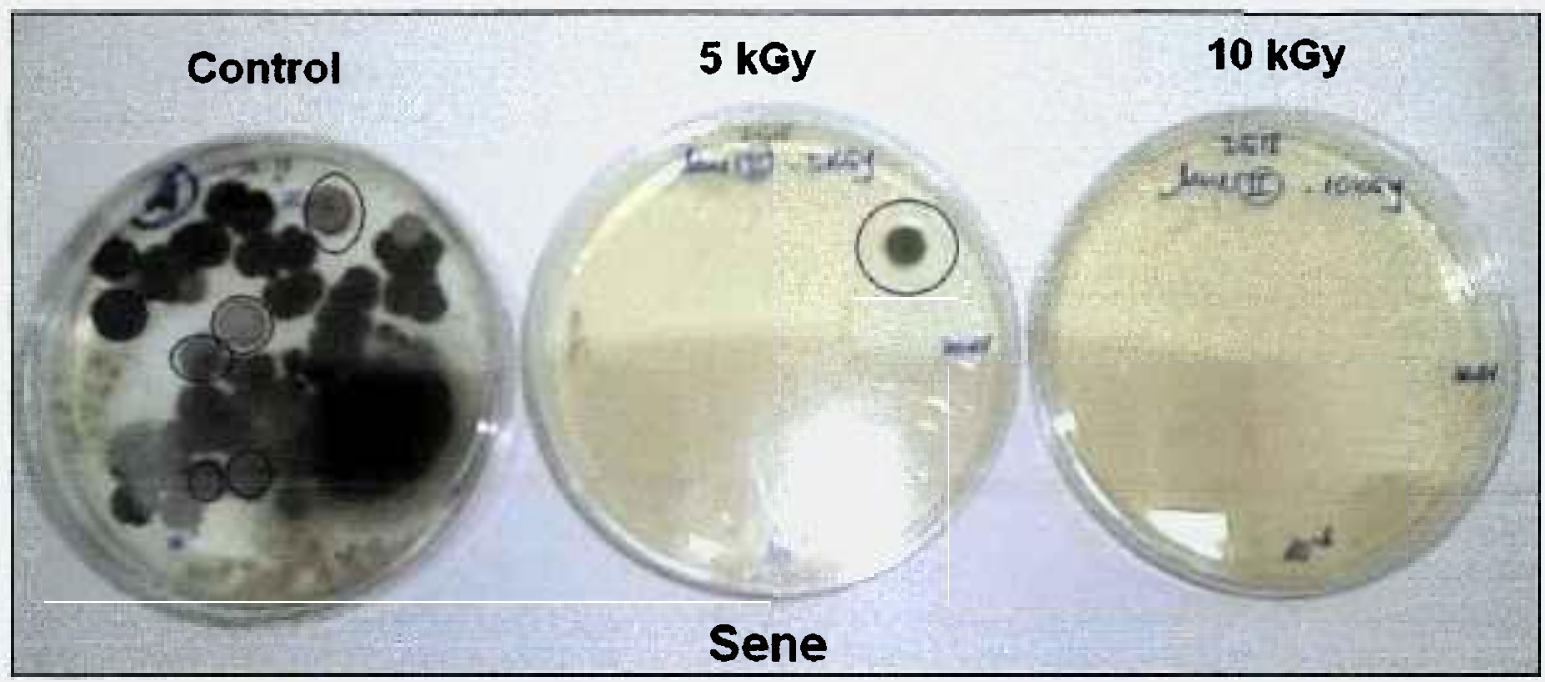

FIGURA 56. Isolados fúngicos em amostras de Sene após 30 dias do tratamento pelo processo de irradiação (controle, 5 e $10 \mathrm{kGy}$ ).

\subsection{Extração de Aflatoxinas das amostras}

\subsubsection{Extração de aflatoxinas (Soares e Rodriguez-Amaya, 1989).}

A análise das amostras de drogas vegetais não revelou a presença de aflatoxinas, em Sene, Boldo, Espinheira santa, Chá verde e Guaraná, empregandose o método desenvolvido por Soares e Rodriguez-Amaya. 


\subsubsection{Imunoextração}

Todas as amostras analisadas, com a técnica de imunoextração, empregando o kit de colunas de imunoafinidade, apresentaram niveis não detectáveis de aflatoxinas. Entre as vantagens da utilização de colunas de imunoafinidade, pode ser citada a maior especificidade do método (elimina os interferentes), purificação do extrato, concentração do analito, facilidade de uso e rapidez da análise (Bugno, 2006).

\section{E Potencial toxigênico das cepas de A. flavus e A. parasizicus isolados}

Os valores obtidos da produção en ágar côco variaran ontie 17,4 a 82.000 $1 \mathrm{gg} / \mathrm{kg}$ para $A F B_{1}$ e desde niveis não detectáveis (ND) a $3.700 \mu \mathrm{g} / \mathrm{kg}$ para $\mathrm{AFB}_{2}$. Não foram detectadas aflatoxinas $G_{1}$ e $G_{2}$, das colônias isoladas de A. parasiticus das amostras de Sene e Boldo, consideradas não produtoras de toxinas. Todas as cepas de A. flavus isoladas das amostras após o tratamento pela radiação ionizante (5 e $10 \mathrm{kGy}$ ) produziram aflatoxinas $B_{1} \in B_{2}$ no teste de potencial toxgenico, indicando que as cepas não perderam esta capacidade apos a irradiação.

\subsection{Testes fitoquímicos qualitativos}

As análises cromatográficas dos extratos estudados demonstraram que as manchas obtidas, correspondentes à substância marcadora dos substratos do grupo controle e irradiados, não diferiram entre si, demonstrando que o tratamento pelo processo de irradiação (nas doses de 5 e 10 kGy) näo provocoli mudanças no Foril flogumico qualitativo des plantas medicinais estudachs, confomin remonstradonas FIG $57,58,59,60,61$ e 62 . 


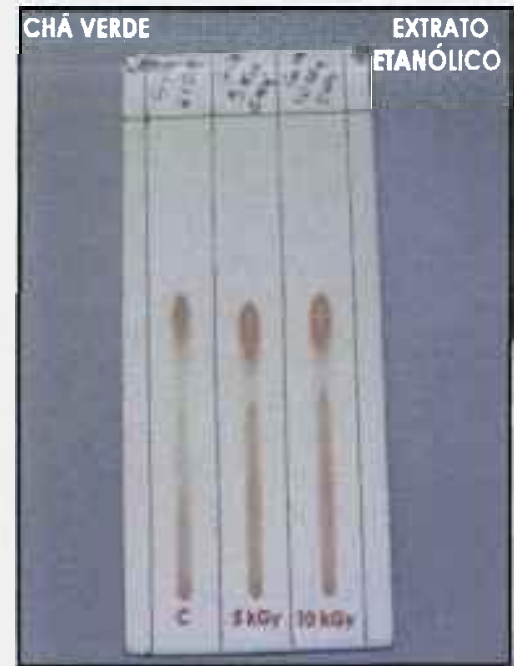

FIGURA 57. Cromatografia (EE) de Cháverde (controle, 5 e $10 \mathrm{kGy}$ )

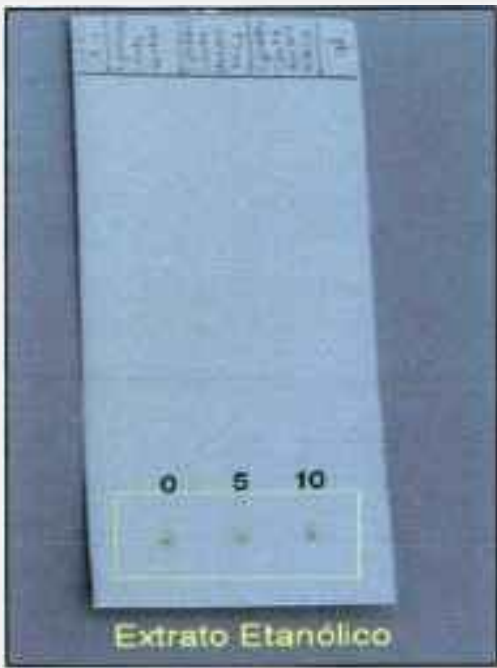

FIGURA 59. Cromatografia (EE) de E. santa (controle, 5 e $10 \mathrm{kGy}$ )

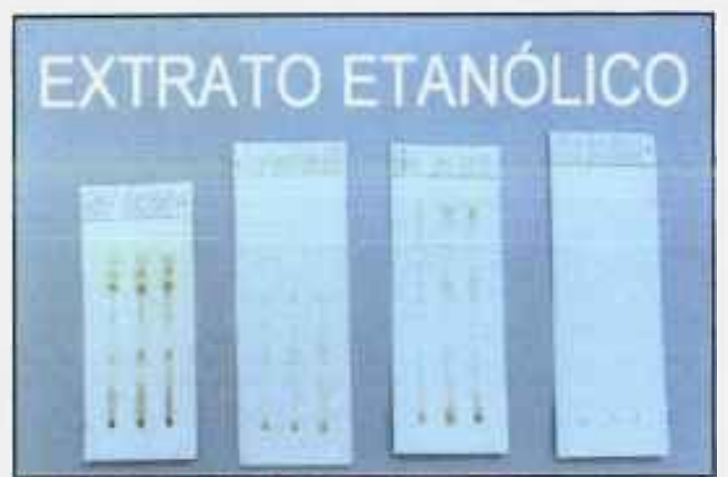

FIGURA 61. Cromatografia (EE) das amostras do grupo controle, 5 e $10 \mathrm{kGy}$

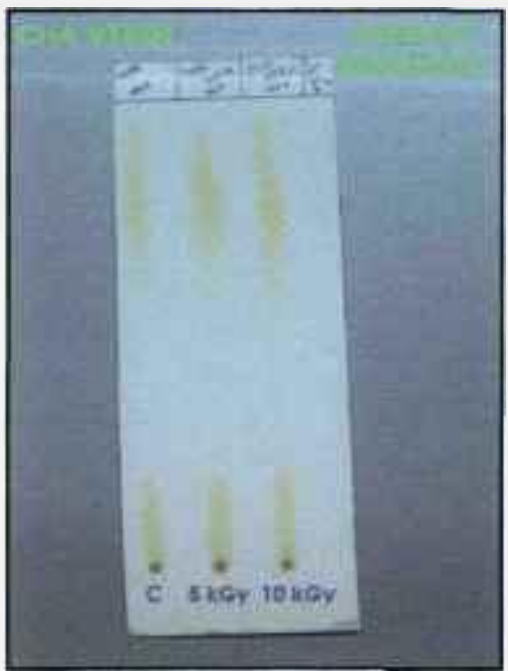

FIGURA 58. Cromatografia (EH) de Cháverde (controle, 5 e $10 \mathrm{kGy}$ )

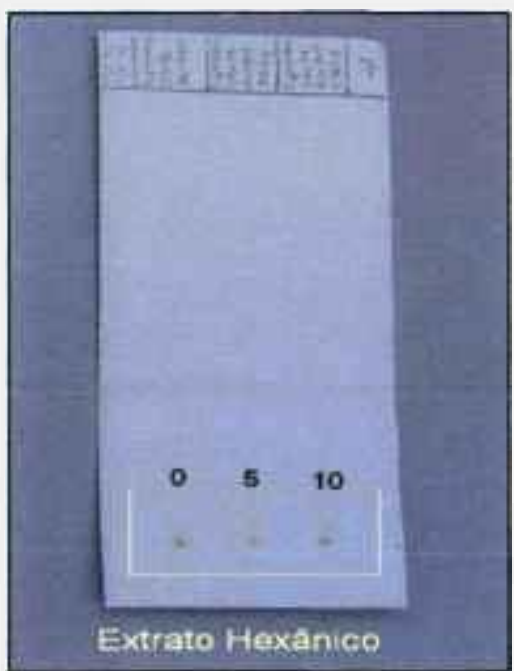

FIGURA 60. Cromatografia (EH) de E. santa (controle, 5 e $10 \mathrm{kGy}$ )

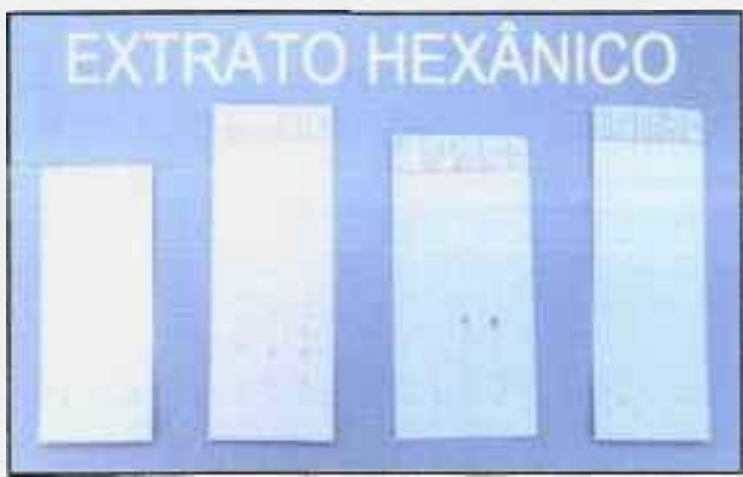

FIGURA 62. Cromatografia (EH) das amostras do grupo controle, 5 e $10 \mathrm{kGy}$ 


\section{DISCUSSÃO}

\subsection{Determinação da atividade de água $(A a)$}

A água é, provavelmente, o mais importante determinante ecológico do crescimento fúngico em produtos estocados, embora outros fatores como, temperatura e composição gasosa também sejam relevantes. Mas nem toda a águlia presente está igualmente disponivel para a colonização de microrganismos, pois parte desta está fortemente presa por ligações químicas ao substrato. Os valores de $A a$ oscilam entre 0 e 1 , sendo que a $A a$ da maioria dos alimentos frescos é superior a 0,99 (Jay, 1978).

A facilidade com que a porção fracamente ligada pode ser removida depende do conteúdo de água do substrato. A disponibilidade cle água no substrato determina não somente quais microrganismos são capazes de se desenvolver,

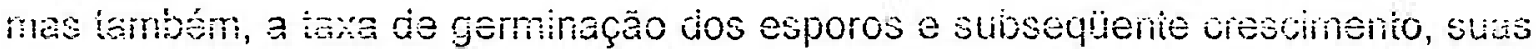
interações com outros fungos, habilidade em produzir esporos e atividades metabólicas (Lacey, 1988). Northolt et al. (1977) verificaram que a atividade de água do substrato desempenha papel importante no crescimento fúngico e produção de micotoxinas.

As necessidades dos microrganismos devem ser expressas en termos de Aa do substrato (Jay, 1978). A Aa tem sido definida como a relação entre a pessâa de vapor da solução $P$ (solutos em água, na maioria dos aimentos) e a pressán de varor $P_{0}$ (usualmente a égua). Isto pode ser expresso metomaticamente pola Lei de Raouit:

$$
\text { Aas } \mathrm{F} / \mathrm{P}_{0}=\mathrm{n}_{1} / \mathrm{n}_{1} \cdot \mathrm{n}_{2}
$$


Onde $P$ é a pressão de vapor de uma solução, $P_{0}$ é a pressão de vapor da água pura, $n_{1}$ é o número de moles do solvente e $n_{2}$ é o número de moles do scluto. A umidade relativa (UR) é ieservada para caracierizar conaiçöes atmosféricas (Troller et al., 1984). Este conceito está, ainda, associado com a umidade relativa (UR) da seguinte forma (Christian, 1963):

\section{$\mathrm{UR}=100 \times A a$}

A Aa está relacionada com a Umidade Relativa em Equilibrio $(E R H)$ da seguinte maneira:

$$
A a=\frac{E R H}{100}
$$

Segundo Kozakiewcz et al. (1994), a Aa mínima para crescimento de $A$. flavus é 0,71 a 0,74 , com valor ótimo de 0,98 , sendo a Aa minimo para a produção de aflatoxina em torno de 0,82 e temperatura compreendendo entre 25 a $37^{\circ} \mathrm{C}$. Pitt e Miscamble (1995) relataram em estudos prévios que a atividade de

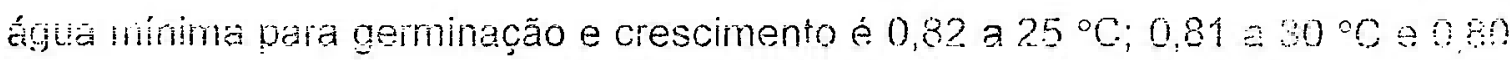
a $37^{\circ} \mathrm{C}$. Hunter (1969) propôs o valor de 0,87 como sendo o limite mínimo de $\mathrm{Aa}$ para a produção de aflatoxinas.

Aquino (2003) observou uma diminuição da Aa de amostras de milho submetidas ao iratamento por radiaçäo gama, onde a Aa dos gräos das amostas controle, girava em torno de 0,75 e após a irradiaçäo com dose de $20 \mathrm{kgy}$, vanaram de 0,55 a 0,65 . Tal fato ocorre pelo éreito da radiólise da égua livre ou disponvel nes amostras.

Mo piesente estudo não foi observacio nas fohas ras dioges veuas (enhaladas ou não) a formaçăo de colónias de fungos visiveis sencio, portanto, os 
valores de $\mathrm{Aa}$ dos substratos analisados (compreendido entre 0,49 a 0,58 ), insuficientes pra germinação e crescimento fúngico diretamente no substrato.

\section{2 Pesquisa da microbiota fúngica do grupo controle}

Segundo Lacey (1989) a maioria dos fungos que contaminam as plantas, antes da colheita, é capaz de crescer dentro de limites mais amplos de $\mathrm{pH}$, pressão osmótica, conteúdo de umidade, bem como, de se desenvolver em temperaturas entre 0 e $30^{\circ} \mathrm{C}$.

Rocha et al. (2004) constataran em amostras de Sene a Doluo, ima freqüência de contaminação fúngica de $92,5 \%$ das amosíras coletadas em mercado e farmácias de manipulação, na cidade de Campinas (SP). Bugno (2006) constatou que $89,9 \%$ das cepas isoladas em 91 amostras de 65 tipos de drogas vegetais corresponderam a gêneros de importância micotoxicológica (Aspergillus e Penicillium).

Com relação à contaminação fúngica, Ẻugno (2006) verificou a presença de A. flavus $(63,7 \%)$, A. parasiticus $(12,1 \%)$, A. ochraceus $(28,65)$, A. niger $(57,15), A$. fumigatus $(8,8 \%)$, Penicillium citrinum $(26,4 \%)$, P. chrysogenum $(34,1 \%)$, Alternaria spp. (14,3\%), Chaetomium spp. (1,1\%) Cladosporium spp. $(2,2 \%)$, Mucor spp. $(4,1 \%)$, Paecilomyces spp. (1,1\%), Phoma spp. (2,2\%), Rhizopus spp. (9,9\%) e Tirioderina spp. $(2,2 \%)$.

Halt (1998) constatou que os gêneros predominantes, em plantss medicinais forani: Aspergillus, Penicillum, Mucor, Rhizopus, Absidia, Altomaria, Cladosporium e Thohoderma. O mesmo autor ainda demonstrou que a freqüencia de Aspergillus flus, on plantas medicinas, foi de 18\%, sugerindo que a materia prina vegota!, amexenada inapropriadamente, permite o decenvolvimento de funcos coxigenicos. 
Aziz et al. (1998) isolaram de 84 amostras de plantas medicinais importadas da Índia e coletadas na cidade do Cairo, os gêneros fúngicos Aspergillus, Penicillium a Fusarium, no entanto, o autor relata que a ciominância dos gêneros Aspergillus e Penicillium, em todas as amostras de plantas medicinais analisadas, se dá em função de duas categorias ecológicas de fungos: fungos de campo e fungos de armazenamento.

Os fungos de campo são observados durante o periodo de germinação e maturação da planta, e entre eles estão os fungos do gênero Fusarium, ao passo que os gêneros pertencentes aos fungos de armazenamento são encontrados em plantas estocadas em condiçōes de umidade rotineiramente encontradas em produtos armazenados e são principaimente fungos do gênêto Áspergillus e Penicilium (Corrêa, 2000).

Tal fenômeno foi observado no presente estudo, uma vez que em todos os tipos de drogas vegetais analisadas, a predominância do gênero Aspergillus foi constatada, estando os resultados de acordo com os relatos da literatura. Do totai de 100 amostías de drogas vegetais analisadas, roi constataco que $95 \%$ apreseniarami contaminação fúngica, sendo que $77 \%$ estavam acina dos limites estabelecidos pela WHO (1998).

\subsection{Freqüência (\%) de isolados fúngicos por locais de venda}

No presenía estudo, a comparação estatística entre fonte atacadisia, farmacias e feiras-livres demonstrou que as drogas vegetais säo igualmente susceptiveis à contaminaçäo fúngica $(p>0,05)$, como resultado do processo do plantio e coineita, independente do local de aquisição e tipo de drofa vegetzi. Do rotal de anostras, 50 a 100\% das plantas medicinais não apresencm qualda assegurada, ou seja, abaixo dos limites preconizados pelas WHO (1988). Excote 
as amostras de Chá verde e Boldo (ambas coletadas na fonte atacadista), onde $67 \%$ e $83 \%$, respectivamente, apresentaram valores dentro dos limites aceitáveis.

Comparativamente as formas de apresentação e locais de venda influenciaram a freqüência de contaminação fúngica das amostras coletadas. Em algumas plantas medicinais estudadas por Abou-Arab et al. (1999), a porcentagem de matéria-prima vegetal contaminada, em amostras embaladas, foi maior do que as não embaladas e, isso se deve a fatores como elevação de umidade no interior da embalagem, métodos inadequados de proteção e más condições de estocagem das embalagens e em tais circunstâncias, ocorrem a elevada contaminação da matéria-prima vegetal por fungos. Rocha e colaboradores (2004) ao analisarem amcstras de Soldo coletadas em mercados e farmácias de manipulaçăo, ha ciudade de Campinas, observaram que $60 \%$ e $40 \%$, respectivamente, apresentaram contaminação acima do limite preconizado pela WHO (1998).

Os mesmos autores constataram que 30\% das amostras de Sene, coletados en mercados, estavam acima do limite. Em amostras de Sene adquiridas de famácias de manipulaça, $50 \%$ apresentaram valores de contaminaço acima dos preconizados. Embora a análise estatística demonstrasse que não havia diferença significativa nos niveis de contaminação, entre os locais de aquisição das amostras $(p>0,10)$, os autores relacionaram a contaminação à manipulação inadequada $\epsilon$ armazenamento incorreto destes produtos, considerando-os de baixa qualidade.

7. 4. Pesquisa da microbiota fúngica (amostres irradiadas).

Após 30 dias do tratamento, observou-se, nas amostras de Espinheira santa e Sene, irradiadas con $5 \mathrm{kGy}$, uma resistencia da microbiota com aumento desia. Entretanto, houve una redução de contaminação do Chá-verde e Boldo, sen Eibracão de contaninaço nas amostres de Guarané, após 30 dias do iratameno. 
O presente estudo demonstrou que os gêneros isolados, após o tratamento por radiação gama na dose de $5 \mathrm{kGy}$, foram Aspergillus, Phoma e Syncephalastrum demonstrando resistência, ein planiás medicinäis iraiadas pelo processo de irradiação. Nenhum gênero anteriormente citado foi isolado, após 30 dias, nos tratamentos com $10 \mathrm{kGy}$, sendo esta dose considerada efetiva na descontaminação do substrato estudado.

Embora a diferença estatística entre as doses de 5 e 10 kGy não seja considerada significativa, a presença de colônias em amostras irradiadas com 5 kGy (tanto no dia 0 e 30 dias após o tratamento) não reflete um fenômeno relacionado com a quantidade de esporos do inóculo ou o tamanho do inóculo, uma yez que isto interfere na produção de micotoxinas, como demonstrauto por Ghama e colaboradores (1980) trabalhando com A. parasiticus e Odamtten et al. (1987), com A. flavus.

Os autores observaram que o meio de cultura, inoculado com um grande número de esporos, apresentou menor quantidade de aflatoxinas do que outro meio inoculado con una caiga menor de esporos. A produça da micotoxine suprimida, quardo o número de esporos inoculados (por unidade de volume do substrato) excede certos niveis (Karunaratne e Bullerman,1990).

O mesmo efeito foi observado com o tratamento aplicada em cevada por fumigação com fosfina ou brometo de metila. Obviamente, a redução de fungos competidores, seja pelo tratamento através do processo de irradiação ou por fumigação, aumentaram a produçäo de micotoxinas (Chelak et al, 1991; Borsa el al. 1992). Portanto, a dose de escolha no controle de fungos toxigenicos, deve sor aquela que elimina a contaminação fúngica en sua totalidade. No presente estido, a dose de 10 kGy demonetrou ser a escolha mais eficiente. 
Salama et al. (1977) relataram que a variação na resistência fúngica à radiação é devido ao conteúdo de água no micélio e à produção de radioprotetores químicos naturais. Os fungos eláboram numerosos proudutos metábúlicos como álcoois, ácidos, enzimas, pigmentos corantes, polissacarídeos, esteróis e alguns produtos de natureza complexa como ergotinina, antibióticos como penicilina, notatina, flavicina, fumigacina e espinosilina. A literatura ainda cita que tais constituintes intracelulares fúngicos (compostos sulfidricos, pigmentos, amino ácidos, proteínas e ácidos graxos) são os responsáveis pela radioresistência (Aziz et al., 1997; Silveira, 1995).

Outros autores relacionam o aumento da radioresistência de microrganismos com o aumento das duplas ligações carbono carbono na membrana lipidica, uma vez que os fosfolipidios são essenciais tanto na estrutura como na função da membrana celular (Redpath e Patterson, 1978). As paredes celulares dos fungos contêm apreciáveis frações de lipídios (até 20\%) como no caso de algumas espécies de Aspergillus (Harwood e Russel, 1984).

Abu Shady et al (1992) concluiram que a resistência à radiação é proporcional à concentração total de lipídios, em células bacterianas. Aziz (1997) relaciona a radioresistência de esporos com a porcentagem dos lípides totais do micélio. Os mesmos autores relataram que a quantidade de lipídios no micélio de A. flavus é de $7,8 \%$.

Mecanismos de reparo do DNA também estão envolvidos na resistência à raciiação ionizante e entre os microrganismos que demonstram tal habilidade estäo ircluidos os fungos (Borecham e Mitchel, 1901). Entretanto, Generos fúngicos ponientados demonstraram dominância, en relação aos oubos gêneros encontrados no solo, dos arreciores do acidente de Chemobyl, contendo radionuclideos de meia vida longa (Zhdanova et al., 1994.). 
O gênero Alternaria é conhecido pela resistência em ambientes com elevados níveis de radiação e algumas espécies de Alternaria demonstraram tolerância às doses de 4,0 kGy (Beraha et al., 1960, Maity ot al., 2004). A espécie A. alternata é conhecida por produzir melanina, um pigmento negro acumulado no interior do micélio (Kimura e Tsuge, 1993).

Cepas coletadas de Alternaria alternata, em ambientes contaminados com radioisótopos, no Reator $n^{\circ} 4$ ChNPP, em Chernobyl, foram usadas como modelo de estudo genético sobre a resistência à radiação gama (Mironenko et al., 2000). Estudos prévios associaram a radiorresistência de microrganismos como resultado da melanização de suas células (Pointing et a!., 1996).

Nenhum estudo, até o presente momento, relata a resistência à radiação gama dos gêneros Phoma e Syncephalastrum em plantas medicinais ou em outro substraio.

Deve-se considerar que a maioria das plantas medicinais é consumida como folhas desidratadas para infusão, mas é possivel encontrar no meicado, produtos como Sene em pó, cuja forma de ingestão é ieita sem o preparo com água acima de $74^{\circ} \mathrm{C}$ e semelhante ao consurno de Guaraná em pó, diluído em água fria, embora as aflatoxinas sejam termoestáveis.

\subsection{Extração de aflatoxinas}

7.5.1 Método: Soares Rodriguez Amaya (1989).

O método de extração empregado não demonstrou ser eficiente na elapa de cromatografia en camada delgada, apresentando pigmentos indesejáveis na corrida. Entretanio, foi possivel observar a ausência de aflatoxinas após o teste, em todas as amostras analisadas, dos cinco tipos de drogas vegatais. Portanto, 
conforme demonstrado no presente estudo, os resultados apresentados estão de acordo com os dados obtidos por Bugno (2006), que demonstrou a ausência de micotoxinas (aflatcxinas, ocratoxira $A$ ou citrinina) em 91 amosiras de 65 uipos de plantas medicinais, empregando a técnica descrita.

Resultados similares foram obtidos por Aziz et al. (1997) que detectaram alta incidência de espécies toxigênicas (que produziram micotoxinas em meios sintéticos) de Aspergillus, Fusarium e Penicillium, mas não detectaram a ocorrência de micotoxinas nas amostras de plantas medicinais, de onde os fungcs foram isolados.

Embora alguns trabalhos relatem a ocorrencia de micotoxinas emin anostras de drogas vegetais, diversos autores sugerem que drogas vegetais não oferecem condições para a expressão da capacidade toxigênica dos contaminantes, sendo este o motivo para a baixa ocorrência natural de micotoxinas (Abou-Arab et al., 1999; Lutomski e Kedzia, 1980).

Abou-Arab et al. (1998), analisando plantas medicinais no Egio, isolam fungos toxigênicos com elevada freqüência, como Penicillium spp., A. niger e Fusarium spp. Todavia, os autores relatam que todas as amostras apresentaramse isentas da contaminação natural de micotoxinas.

\section{5 .2 Imunoextração}

Durante a análise realizada nas amostras de Guaraná em pó, observou-se a presença de pigmentos marrons nos extratos e, portanto, foi necessário realizar una filtração previa das amostras, para impedir obstrução da coluna. Os resultados obtidos no presente estudo foram semelhantes aos encontrados por ithokoto et ai (1978) que analisaram 49 amostras de drogas vegetais em pó, nas uuals năo foram detectadas micotoxinas, dentre elas, as aflatoxinas. 0 extrato obtido empreganó- 
se o Kit Aflatest demonstrou estar límpido e isento de pigmentos, observados na cromatografia em camada delgada, do extrato obtido pela técnica de Soares e Rodriguez-Amaja.

O emprego de colunas de imunoafinidade demonstrou ser um método eficiente para evitar pigmentos interferentes, conforme discutido por Romagnoli e colaboradores (2007) ao realizar a extração de aflatoxinas em condimentos. Romagnoli et al. (2007) empregou colunas de imunoafinidade na detecção de aflatoxinas em 28 amostras de condimentos, 48 amostras de plantas medicinais e 27 amostras de chás aromáticos na Itália e constataram que as amostras de plantas medicinais não apresentaram niveis detectáveis de aflatoxinas.

Os autores justificaram a ausência da formação de aflatoxinas, nestes substratos, por não serem favoráveis, uma vez que contêm óleos essenciais em sua composição, com propriedades antifúngicas. Além disso, a atividade de água (Aa) das amostras, que variaram de 0,47 a 0,58 (TAB. 3), e representa um fator determinante da não detecção de micotoxinas nestes substratos, uma vez que a $\mathrm{Aa}$ minima para que coorra a produção de aflatoxinas esté em torno de 0.82 e temperatura compreendendo entre 25 a $37^{\circ} \mathrm{C}$ (Kozakiewcz et al., 1994).

Embora algumas publicações relatem a presença de aflatoxinas em plantas medicinais, a maioria dos trabalhos não apresenta a $\mathrm{Aa}$ dos substratos. Ali e colaboradores (2005) pesquisaram a ocorrência naturai de aflatoxinas em plantas medicinais da Indonésia e Malásia, usando colunas de imunoafinidade e cromatografia licuida de alta eficiência (CLAE). Em 23 amostras comerciais analisadas, os niveis detectados foram de: $0,26 \mu \mathrm{g} / \mathrm{kg}$ de AFB $, 0,07 \mu \mathrm{g} / \mathrm{kg}$ de $A F B_{2}, 0,10 \mu \mathrm{g} / \mathrm{kg}$ de $A F G_{1}$ e $0,03 \mu \mathrm{g} / \mathrm{kg}$ de $A F G_{2}$ e segundo os autores, tais resulados estavam abaixo de valores de aflatoxinas encontrados em matoriasprimas cruas de drogas vegetais relatadas por outros autores. 
Apesar da hipótese de que as drogas vegetais não sejam substratos adequados à produção de micotoxinas, Bugno (2006) demonstrou que amostras de matéria-piima intencionalmente contaminadas de alcachoira reveiaram a presença de aflatoxinas $B_{1}$, indicando que a matéria-prima vegetal forneceu substrato adequado à expressão da capacidade toxigênica do fungo $A$. flavus, quando fornecidas condições adequadas de temperatura e umidade $\left(26^{\circ} \mathrm{C}\right.$ e $88 \%$, respectivamente).

\subsection{Potencial toxigênico das cepas de A. flavus isolados}

Taxonomicamente, as espécies de Aspergillus estão agrupadas dentro dos fungos imperfeitos, onde somente a reprodução assexuada é conhecida (Gains e Samson, 1985). Estes microrganismos estão presentes no solo e matéria vegetal e são transmitidos às plantas, no campo, onde a contaminação e a produção de aflatoxinas estão frequentemente associados ao "stress" da planta e danos por insetos (Richard et al., 1993).

Especificamente, vários trabalhos já enfocaram a produção de aflatoxinas pelo A. fiavus (Almeida, 1996), entretanto, Shilo (1940), Levitski e Koniukhova (1947) foram os primeiros investigadores a estudar a potencialidade toxigênica do fungo A. flavus em meios de cultura. Diner e Davis (1966) e Schindler et al. (1967) observaram, em meio de cultura, a produção de aflatoxinas por Aspergillus flavus.

Zevada (1971) estudou a produção de aflatoxinas, por 9 cepas de A. flavus, isoladas de grãos de milho, em 5 diferentes meios de cultura, senćo que todas as cepas produziram aflatoxinas em pelo menos um dos meios.

Mehan e Chohan (1973), estudando a capacidade de produçäo de aflatoxina de 21 isolados de A. flavus (provenientes de milho, algodão e trigo), verificarain que 16 cepas $(76,1 \%)$ produziram aflatoxinas $B_{1}$ na concentração de 17.000 a 
$344.000 \mu \mathrm{g} / \mathrm{L}(\mathrm{ppb})$. Oliveira (1996) estudou o potencial toxigênico de 50 cepas isoladas de $A$. flavus em rações de aves, onde $44 \%$ produziram aflatoxina $B_{1}$ em niveis que variaram de 79 a $2835 \mu \mathrm{g} / \mathrm{kg}$ ou ppi. Aimeida et al. (2005) relataram que das 14 cepas de A. flavus isoladas de milho, provenientes de Capão Bonito/SP e Ribeirão Preto/SP, $13(92,9 \%)$ produziram aflatoxinas após o teste do potencial toxigênico.

De acordo com Geisen (2000), 40 a 50\% das cepas de A. flavus são capazes de produzir $A F B_{1}$ e $A F B_{2}$. Tal observação já havia sido citada por Pier (1990) que verificou em condições laboratoriais, que nem todas as cepas de fungos são capazes de produzir toxinas e que somente $50 \%$ das cepas de A. flavus são produloras de aflatoxinas. O mesmo autor relatou ainda que, $90 \%$ das cepas de $A$. flavus produzem $A F B_{1}$ e $A F B_{2}$, e que $10 \%$ produzem somente $A F B_{1}$.

Em estudos, com cepas isoladas em amendoim, realizados por Lisker et al. (1993) a produção simultânea de aflatoxina $B$ e $G$ foi observada somente em $0,5 \%$ dos isolados e que $98 \%$ das cepas isoladas eram $A$. flavus e somente $2 \%$ eram $A$. parasiticus. Tais observações estão de acordo com os achados do presente estudo, uma vez que não foi observada a produção de $A F G_{1}$ e $A F G_{2}$ no meio inoculado com os isolados de A. parasiticus, das amostras de Boldo e Sene.

Poucos são os relatos de teste do potencial toxigênico (em meio ágar côco) de A. flavus, isolados de plantas medicinais, tampouco de material vegetal irradiado. Bugno et al. (2006) demonstraram que 42,9\% de fungos do gênero Aspergillus, isolados em 91 amostras de drogas vegetais, demonstraram a capaciciade de produzir aflatoxinas, em ágar côco.

Em todas as amostras (grupo controle) analisadas, no presente estudo, foi encontrado Aspergillus flavus e do total de colonias isoladas de A. flavus, 41\% produziram $A F B_{1}$ e $A F B_{2}$ confirmados peio teste de potencial toxigenico, 
consideradas cepas toxigênicas. Foi possível observar ainda que, todas as cepas de A. flavus isoladas das amostras após o tratamento pelo processo de irradiação, nas doses de 5 e $10 \mathrm{kGy}$, produziram $A F B_{1} \in A F B_{2}$ no teste de potencial toxigênico, indicando que as cepas não perderam esta capacidade após o processo.

\subsection{Testes fitoquímicos qualitativos}

Young et al. (2004) submeteram aos testes in vitro de genotoxicidade a Paeoniae Radix, uma raiz usada na China para o tratamento de doenças hepáticas. O teste de Ames e em culturas de células ovarianas de hamsters, não demonstraram mutagenicidade e, tampouco toxicidade citogenẻtica em cultura de células, da erva irradiada com a dose de $10 \mathrm{kGy}$. A cromatografia também demonstrou que a quantidade do princípio ativo da raiz não foi alterada significativamente com o tratamento, demonstrando que o processo de irradiação foi toxicologicamente seguro e quimicamente estável.

Efeitos da radiação gama em ervas medicinais coreanas foram estudadàs por Myung et al. (1999). Os autores constataram que funções antioxidantes, atividades anticomplementares, assimilação de nitritos e habilidade de doação de elétrons de plantas medicinais na Coréia, tratadas com a dose de 10 kGy não diferiram de amostras controles (não irradiadas).

Soriani et al. (2005) demonstraram que as concentrações de cafeina em Guaraná, não forma afetadas pela radiação gama até a dose de 17,8 kGy. As diferenças entre amostras irradiadas e não irradiadas não foram estatisticamente significantes. Os autores ainda relataram que não houve evidências de redução de glicosideos flavonóides totais em Ginkgo biloba, após o tratamento pelo processo de irradiação. 
Não houve alteração do perfil fitoquímico das amostras de Boldo, Espinheira santa, Chá verde, Guaraná e Sene, tratadas com as doses de 5 e 10 kGy. Os resultados chtidos estão de acordo com os dados encontrados em literatura. Koseki e colaboradores (2002) demonstraram, através de análises cromatográficas, que não houve diferença significativa nos niveis de flavonóides, compostos fenólicos, taninos e óleos essenciais de diferentes extratos de ervas desidratadas, tratadas pelo processo de irradiação, com doses de 10, 20 e 30 kGy. 


\section{CONCLUSÕES}

- Diversos gêneros fúngicos foram isolados de drogas vegetais, independentes do tipo e forma de venda. Foi possivel observar que os menores niveis de contaminações ocorrem durante a etapa de venda no atacado, comparativamente às amostras encontradas no varejo (feiras e farmácias).

- Observou-se que os gêneros Aspergillus, Syncephalastrum e Phoma apresentam resistência às doses de $5 \mathrm{kGy}$, comparativamente aos diversos gêneros isolados.

- Em relação às espécies do gênero Aspergillus, $A$. niger e $A$. flavus apresentaram resistência à radiação na dose de 5 kGy.

- As doses empregadas de 5 e 10 kGy, não interferiram na capacidade de fungos toxigênicos isolados, em produzir micotoxinas, como observado com o A. flavus no teste de potencial toxigênico.

- A manutenção da droga vegetal irradiada, em embalagens íntegras, garante a qualidade microbiológica após 30 dias do tratamento com radiação gama, empregando-se a dose de $10 \mathrm{kGy}$, que demonstrou ser eficiente na eliminação da microbiota fúngica (de 85 a $100 \%$ ). 
- Não foi detectada a presença de aflatoxinas nos substratos vegetais, comparando-se as duas técnicas de extração. O material vegetal desidratado não é um substrato viável para fungos toxigênicos, uma vez que os valores de Aa encontravam-se abaixo do limite ideal para a produção de micotoxinas.

- O tratamento pelo processo de irradiação deve ser empregado para o controle microbiológico de plantas medicinais comercializadas, uma vez que este método não causou alterações químicas nos extratos estudados das plantas, após cromatografia, não interferindo na sua composição química.

- A elevada contaminação de cinco tipos de drogas vegetais, observada em UFC/g, representa um sério risco ocupacional para manipuladores, através da inalação de esporos e, o tratamento pelo processo de irradiação, pode garantir a saúde dos profissionais de indústria e comerciantes.

- A redução da microbiota fúngica de plantas medicinais, com doses a partir de $10 \mathrm{kGy}$, previne a contaminação cruzada para as residências dos consumidores, uma vez que no interior de suas cozinhas, tais fungos podem encontrar um substrato adequado para seu crescimento e produção de micotoxinas, tão danosas à saúde pública.

- Através da análise da contaminação fúngica, o presente estudo abre novas discussões quanto ao controle e fiscalização da matéria-prima vegetal, utilizada pelos consumidores e pela indústria farmacêutica, sugerindo uma nova abordagem da legislação brasileira, pelas autoridades sanitárias, enfatizando o controle de fungos e micotoxinas em plantas medicinais e a inclusão de métodos de descontaminação, como o tratamento por radiação ionizante. 


\section{REFEREAHCIAS GIBLIOSRÁFICAS}

1. ABOU-ARAB, A. A. K. ; KAWTHER, M. S., EL TANTAWY, M. E. ; BADEAA, R. I. ; KHAYRIA, N. Quantity estimation of some contaminants in commonly used medicinal plants in the Egyptian market. Food. Chem., v. 67, p. 357363, 1999.

2. ABOU-SHADY, M. R.; EL-BEIH F., M.; TAWFIK Z. S. Role of lipids in bacterial radioresistance. $5^{\text {th }}$ Cont. Nucl. Sci. Appl., v. 2, p. 513-523, 1992.

3. ABU-IRMAILEH B. E.; AFIFI, F. U. Herbal medicine in Jordan with special emphasis on commonly used herbs. J. Ethnopharmacol., v. 89, p. 193-197, 2003.

4. AQUINO, S. Efeitos da radiação gama no crescimento de Aspergillus flavus produtor de aflatoxinas e no emprego da Técnica da reação em cadeia da Polimerase (PCR) em amostras de grãos de milho inoculadas artificialmente. 2003. Dissertação (Mestrado) - Instituto de Pesquisas Energéticas e Nucleares, São Paulo.

5. AQUINO, S.; FERREIRA, F.; RIBEIRO, D. H. B.; CORREAA, B.; GREINER, R.; VILLAVICENCIO, A. L. C.H. Evaluation of viability of Aspergillus flavus and aflatoxins degradation in irradiated samples of maize. Braz. J. Microbiol., v. 36, p. 352-356, 2005.

6. ALEXANDER, R. G.; WILSON, D. A.; DAVIDSON, A. G. Medicines control agency investigation of the microbial quality of herbal products. The Pharmaceutical Journal, v. 259, p. 259-261, 1997.

7. ALI, N.; HASHIM, N.H.; SAAD, B.; SAFAN, K.; NAKAJIMA, M.; YOSHIZAWA, T. Evaluation of a method to determine the natural occurrence of aflatoxins in commercial traditional herbal medicines from Malaysia and Indonesia. Food Chem. Toxicol., v. 43, p. 1763-1772, 2005.

8. ALMEIDA, A. P. Microbiota fúngica e produção de af́latoxinas e fumonisinas, por cepas de Aspergillus flavus Link e Fusarium moniliforme Sheldon, de três hibridos de grãos de milho recém. colhido. 1996. Dissertação (mestrado) - Instituto de Ciências Biomédicas da Universidade de São Paulo, São Paulo.

9. ALMEIDA, A. P.; SABINO, M.; FONSECA, H.; CORREA, B. Potencial toxigênico das cepas de Aspergillus flavus e Fusarium verticillioides isoladas 
de grãos de milho, da semeadura à colheita, provenientes das regiões de Capão Bonito/SP e Ribeirão Preto/SP. Rev. Inst. Adolfo Lutz, v. 64, n. 1, p. 79-84, 2005.

10. ARX, J. A. The genera of fungi sporulating in pure culture. 2. ed. Vaduz, J. Cramer, 1974.

11. $A Z I Z, N . H . ; A B D E L-A A L, S . S$. Influence of potassium sorbate and sodium benzoate on gamma irradiated conidia of Aspergillus ochraceus, Penicillium chrysogenum and Fusarium moniliforme. Isot. Rad. Res., v. 22, p. 113-150, 1990.

12. AZIZ N. H.; M. Z. EL-FOULY; M. R. ABU-SHADY; L. A. A. MOUSSA. Effect of Gamma radiation on the Survival of Fungal and Actinomycetal Florae Contaminating Medicinal Plants. Appl. Radiat. Isot., v.48, n.1, p. 71-76, 1997.

13. AZIZ, N. H.; YOUSSEF, Y. A.; EL-FOULY, M. Z; MOUSSA, L. A. Contamination of some common medicinal plant samples and spices by fungi and their mycotoxins. Bot. Bull. Acad. Sin., v. 39, p. 279-285, 1998.

14. AZIZ, N. H.; MOUSSA, A. A. Influence of gamma-radiation on mycotoxin producing moulds and mycotoxins in fruits. Food Control, v.13, p. $281-288$, 2002.

15. BENT, S.; KO, R. Commonly used herbal medicines in the United Sattes: a review. Am. J. Med., v. 116, p. 478-485, 2004.

16. BENNET, J. W.; KLICH, M. Mycotoxins. Clin. Microbiol. Reviews, v. 16, n.13, p. 497-516, 2003.

17. BERAHA, L.; SMITH, M. A.; WRIGHT, W. R. Gamma radiation dose response of some decay pathogens. Phytopathology, v. 50, p. 474-476, 1960.

18. BOREHAM, D. R.; MITCHEL, R. E. J. Heat and radiation stress response regulation in yeast by HSP104. Radiat. Res., v.137, p.190-195, 1994.

19. BORSA, J.; CHELAK, W. S.; MARQUARDT, R. R.; FROHLICH, A. A. Comparison of irradiation and chemical fumigation used in grain disinfestations on production of ochratoxin $A$ by Aspergillus alutaceus in treated barley. J. Food Prot., v. 55, p. 990-994, 1992.

20. BRANDÃO, M. G. L.; FREIRE, N.; SOARES, C. D. V. Vigilância de fitoterápicos de Minas Gerais. Verificação da qualidade de diferentes 
amostras comerciais de camomila. Cad. Saúde Pública, v. 14, p. 613-616, 1998.

21. BRITISH PHARMACOPEIA. London: The Stationery Office, 2004, v. IV, p. A 350, A 452-453.

22. BRASIL. LEI Federal $n^{\circ} 6.360$, de 23 de setembro de 1976. Dispõe sobre a vigilância sanitária a que ficam sujeitos os medicamentos, as drogas, os insumos farmacêuticos e correlatos, cosméticos, saneantes e outros produtos... Diário Oficial da União; de 24 de setembro de 1976.

23. BRASIL. SVS/MS - Secretaria de Vigilância Sanitária /Ministério da Saúde. Portaria No 451, de 19 de setembro de 1997. Aprova o Regulamento Técnico Princípios Gerais para o Estabelecimento de Critérios e Padrões Microbiológicos para Alimentos e seus Anexos I, II e III. Diário Oficial da União, de 22 de setembro de 1997.

24. BRASIL. ANVISA - Agência Nacional de Vigilância Sanitária. Resolução de Diretoria Colegiada - RDC No 17, de 24 de fevereiro de 2000. Dispõe sobre o registro de medicamentos fitoterápicos. Publicada no D.O.U. - Diário Oficial da União, de 25 de fevereiro de 2000.

25. BRASIL. ANVISA - Agência Nacional de Vigilância Sanitária. Resolução RDC No 12, de 02 de janeiro de 2001. Aprova o Regulamento Técnico sobre padröes microbiológicos para alimentos. Publicada no D.O.U. Diário Oficial da União; Poder Executivo, de 10 de janeiro de 2001.

26. BRASIL. ANVISA - Agência Nacional de Vigilância Sanitária. Resolução RDC No. 48, de 16 de Março de 2004. Dispõe sobre o registro de medicamentos fitoterápicos. D.O.U. - Diário Oficial da União, de 18 de março de 2004.

27. BRASIL. ANVISA - Agência Nacional de Vigilância Sanitária. Resolução RE $n^{0} .88$, de 16 de março de 2004. Determina a publicação da "Lista de referências bibliográficas para avaliação de segurança e eficácia de fitoterápicos". D.O.U. - Diário Oficial da União, de 18 de março de 2004.

28. BRASIL. Ministério da Agricultura, Pecuária e Abastecimento. Boas Práticas Agricolas (BPA) de plantas medicinais, aromáticas e condimentares - Brasília: MAPA/SDC. Biblioteca Nacional de Agricultura BINAGRI, 2006.

29. BRASIL, 2006. Ministério da Saúde, Gabinete do Ministro. Portaria n. ${ }^{\circ} 971$, de 3 de maio de 2006. Aprova a Política Nacional de Práticas Integrativas 
e Complementares (PNPIC) no Sistema Único de Saúde. D.O.U. - Diário Oficial da União, n. ${ }^{\circ} 84$ de 04 de maio de 2006.

30. BRASIL, 1994. Ministério da Saúde, Gabinete do Ministro. Portaria $n^{0} 123$, de 19 de outubro de 1994. Estabelece normas para o registro de fitoterápicos. Diário Oficial da União, Brasilia, DF, 20 out. 1994. Disponível: <http://www.anvisa.gov.br/legis/>. Acesso em: 02 abr. 2007.

31. BUGNO, A.; MATOS, D.; PINTO, T.J.A. Contaminação fúngica em plantas medicinais. Rev. Bras. Cienc. Farm., v. 38, p. 87, 2002. Suplemento 1.

32. BUGNO, A.; ALMODOVAR, A. A. B.; PEREIRA, T. C.; PINTO, T. J. A.; SABINO, $M$. Occurrence of toxigenic fungi in herbal drugs. Braz. J. Microbiol., v. 37, p. 47-51, 2006.

33. BUGNO, A. Drogas vegetais: avaliação da contaminação microbiana e pesquisa de aflatoxinas, ocratoxina A e citrinina, 2006. Tese (Doutorado) - Faculdade de Ciências Farmacêuticas da Universidade de São Paulo, São Paulo.

34. CALIXTO, J. B. Efficacy, safety, quality control, marketing and regulatory guidelines for herbal medicines (phytotherapeutic agents). Braz. J. Med. Biol. Res., v. 33, p. 179-189, 2000.

35. CALIXTO, J. B. Twenty-five years of research on medicinal plants in Latin América. A personal view. J. Ethnopharmacol., v. 100, p.131-134, 2005.

36. CAPASSO, F. The medicinal plants in our time. Boll. Chim. Farm., v. 125, n. 9, p. $322-327,1996$.

37. CAPASSO, L. 5300 years ago the Ice Man used natural laxatives and antibiotics. Lancet, v. 352, p. 1864, 1998.

38. CHAN, K. Some aspects of toxic contaminants in herbal medicines. Chemosphere, v. 52, p. 1361-1371, 2003.

39. CHELAK, W.S.; BORSA, J.; MARQUARDT, R.R.; FROHLICH, A.A. Role of the competitive microbial flora in the radiation-induced enhancement of ochratoxin production by Aspergillus alutaceus var. alutaceus NRRL 3174. Appl. Environ. Microbiol. v. 57, p. 2492-2496, 1991.

40. CHOI, D. W. ; KIM, J.H. ; CHO, S.Y. ; KIM, D.H. ; CHANG, S. Y. ; Regulation and quality control of herbal frugs in Korea. Toxicology, v. 181-182, p. 581586, 2002. 
41. CHOURASIA, H. K.; ROY, A. K. Effect of temperatura, relative humidity and Light on aflatoxin $B_{1}$ production in Neem and Datura seeds. Int. J. Pharmacogn., v. 29, p. 197-202, 1991.

42. CHOURASIA, H. K. Mycobiota and mycotoxins in herbal drugs of Indian pharmaceutical industries. Mycol. Res., v. 99, n. 6, p. 697-703, 1995.

43. CHRISTIAN, J. H. B. Water activity and the growth of microorganisms. In: LEITCH, J. M.; RHODES, D. N. (Ed.). Recent Advances in Food Science. London Butterworths, 1963, v. 3, p. 248-55.

44. CIEGLER, A. Fungi that produce mycotoxins: condition and occurrence. Mycopathologia, v. 65, p. 5-11, 1978.

45. CORREAA, B.; GALHARDO, M.; COSTA, E. O.; SABINO, M. Distribution of molds and aflatoxins in dairy cattle feeds and raw milk. Rev. Microbiol., v. 28, p. 279-283, 1997.

46. CORREA, B. Micotoxinas humanas e micetismos. In: ZAITZ, C.; CAMPBELL, I.; MARQUEZ, S. S.; RUIZ, L. R. B.; SOUZA, V. M. (Ed.). Compêndio de micologia médica. Rio de Janeiro: Medsi, 1998, p. 339-346.

47. CORREAA, B. Fungos Toxigênicos: Panorama nacional. In: SCUSSEL, V. M. (Ed.) Atualidades em Micotoxinas e Armazenagem de grāos. Florianópolis, Santa Catarina, 2000, p. 163-168.

48. CONSELHO REGIONAL DE FARMÁCIA. Medicamentos fitoterápicos. Disponivel em: < www.crfsp.org.br > Acesso em 03 de outubro de 2006.

49. COUNCIL FOR AGRICULTURAL SCIENCE AND TECHNOLOGY, Mycotoxins: Risks in Plant, Animal and Human Systems. Task Force Report, n.139, 2003.

50. CZECH, E.; KNEIFEL, W.; KOPP, B. Microbiological status of commercially avaiable medicinal herbal drugs - a screening study. Planta Med., v. 67, p. 263-269, 2001.

51. DALEZIOS, J.I; HSIEH, D.P.H.; WOGAN, G.N. Excretion and Metabolism of Orally Administrated Aflatoxin $\mathrm{B}_{1}$ by Rhesus Monkey. Food Cosmetic Toxicol., v. 11. p. 605, 1973.

52. DE SMET, P.A.G.M. Health risks of herbal remedies: an update. Clin. Pharmacol. Ther., v. 76, p. 1-17, 2004. 
53. DIEHL, J.F. Safety of Irradiated Foods. 2 ed. revised and expanded. Marcel Dekker. New York, USA. 1995.

54. DIENER, U. L. \& DAVIS, N. D. Aflatoxin production by isolates of Aspergillus flavus. Phytopathology, v. 50, p. 1390-3, 1966.

55. DI STASI, L. C. (org.). Plantas medicinais: arte e ciência. Um guia de estudo interdisciplinar. UNESP, São Paulo, p. 230, 1996.

56. EFUNTOYE, M. O. Fungi associated with herbal drug plants during storage. Mycopathologia, v. 136, p. 115-118, 1996.

57. EFUNTOYE, M. O. Fungi associated with herbal drug plants during storage. Mycopathologia, v.136, p. 115-118, 1999.

58. ELSHAFIE, A. E.; AL-LAWATIA, T.; AL-BAHRY, S. Fungi associated with black tea and tea quality in the Sultanate of Oman. Mycopathologia, v. 145, p. 89-93, 1999.

59. El-Far F.; Aziz N. H.; Hegazy, S. Inhibition by gamma-irradiation and microbial food additives of aflatoxin $B_{1}$ production by Aspergillus flavus in poultry diet. Die Nahrung, v. 36, p. 143-149, 1992.

60. EUROPEAN PHARMACOPEIA. $3^{\text {a }}$ ed. Paris: Council of Europe, 2000, p. $70-$ 78.

61. FARMACOPÉIA BRASILEIRA. Parte 1. $4^{\mathrm{a}}$ ed. São Paulo: Atheneu, 1988. p.V.5.1.6.-1-V.5.1.7.-6.

62. FARMACOPÉIA BRASILEIRA. Parte II, fascículo 1. $4^{\mathrm{a}}$ ed. São Paulo: Atheneu, 1996.

63. FARMACOPÉIA BRASILEIRA. Parte II, fascículo 2. $4^{\mathrm{a}}$ ed. São Paulo: Atheneu, 2002.

64. FARMACOPÉIA BRASILEIRA. Parte II, fascículo 3. $4^{\mathrm{a}}$ ed. São Paulo: Atheneu, 2003.

65. FARMACOPÉIA BRASILEIRA. Parte II, fascículo 4. $4^{\mathrm{a}}$ ed. São Paulo: Atheneu, 2004.

66. FARMACOPÉIA BRASILEIRA. Parte II, fasciculo 5. $4^{\mathrm{a}}$ ed. São Paulo: Atheneu, 2005. 
67. FENNEL, C. W.; LIGHT, M. E.; SPARG, S. G. ; STAFFORD, G. I.; VAN STADEN, J. Assessing African medicinal plants for efficacy and safety: agricultural and storage practices. J. Ethnopharmacol. v. 95, p. 113-121, 2004.

68. FISCHER, D. C. H. ; OHARA, M. T. ; SAITO, T. Contaminação microbiana em medicamentos fitoterápicos sob a forma sólida. Rev. Farm. Bioquim. Univ. de S. Paulo, v. 29, p. 81-88, 1993.

69. GAINS, W. \& SAMSON, R. A. Typification of Aspergillus and species related teleomorph genera. In: SAMSON, R. A. \& PITT, J. I. (Eds.). Advances in Penicillium and Aspergillus Systematics. New York, Plenum Press, 1985.

70. GARCIA, E. S. ; SILVA, A. C. P. ; GILBERT, B. ; CORREA, C. B. V. ; CAVALHEIRO, M. V. S, ; SANTOS, R. R. ; TOMASSINI, T. Biodiversidade: perspectivas e oportunidades tecnológicas. Fitoterápicos. Disponivel em :<http://www.bdt.org.br/publicacões/padct/bio/cap10/Eloi.html>. Acesso em : 16 dez. 2006.

71. GARRIDO, D.; JODRAL, M.; POZO, R,; Mold flora and aflatoxin-producing strains of Aspergillus flavus in spices and herbs. J. Food Prot., v. 55, n.6, p. 451-452, 1992.

72. GEISEN, R. PRC methods for the detection of mycotoxin-producing fungi IN: BRIDGE, P. D.; ARORA, D. K.; REDDY, C. A.; ELANDER, R. P. (Eds.). Applications of PCR mycology, London: CAB International, p. 357, 2000

73. HALT, M., Moulds and mycotoxins in herb tea and medicinal plants. Eur. J. Epidemiol., v. 14, p. 269-274, 1998.

74. HART, B. L. The evolution of herbal medicine: behavioural perspectives. Anim. Behav., v. 70, p. 975-989, 2005.

75. HARWOOD, J. L.; RUSSEL, N. J. Distribution of lipids. In: Lipids in Plants and Microbes (Ed. Friedman). 1984, p. 35-70. Academic Press, New York.

76. HEINRICH, M., RIMPLER, H.; BARRERA, N. A. Indigenous phytotherapy of gastrointestinal disorders in lowland Mixe community (Oaxaca, Mexico): ethnopharmacologic evaluation. J. Ethnopharmacology, v. 36, p. 63-80, 1992.

77. HITOKOTO, H.; MOROZUMI, S.; WAUKE, T.; SAKAI, S.; KURATA, H. Fungal Contamination and Mycotoxin Detection of Powdered Herbal Drugs. Appl. Environ. Microbiol., v.39, n.4,p. 252-256, 1978. 
78. HUNTER, J. H. Growth and aflatoxin production in shelled corn by the Aspergillus flavus group as related to relative humidity and temperature. 1969. Thesis (Ph.D.) - Purdue University, Purdue.

79. INTERNATIONAL AGENCY FOR RESEARCH ON CANCER - IARC. Some naturally occurring substances: food items and constituents, heterocyclic aromatic amines and mycotoxins. In: IARC Monographs on the evaluation of carcinogenic risks to humans, IARC, Lyon, v. 56, 1993.

80. INTERNATIONAL CONSULTATIVE GROUP ON FOOD IRRADIATION ICGFI. Facts about food irradiation, p. 32-33, 1999. Vienna.

81. JARVIS, B. B.; MILLER, J.D. Mycotoxins as harmful indoor air contaminants. Appl. Microbiol. Biotech. v. 66, p. 367-372, 2005.

82. JAY, J. M. Microbiologia Moderna de los Alimentos. Zaragoza, Acribia, p. $491,1978$.

83. KARUNARATNE, A.; BULLERMAN, L. B. Interactive effects of spore load and temperature on aflatoxin production. J. Food Protect. v. 53, p. 227-229, 1990.

84. KIMURA, N.; TSUGE, T. Gene cluster involved in melanin biosynthesis of the fillamentous fungus Alternaria alternata. J. Bacteriol. v. 175, p. 44274435, 1993.

85. KNEIFEL, W.; CZECH, E.; KOPP, B. Microbial contamination of medicinal plants - a review. Planta Med., v. 68, p. 5-15, 2002.

86. KOSEKI, P.M; VILLAVICENCIO, A. L. C.H.; BRITO, M. S.; NAHME, L. C. ; SEBASTIÃO, K. I.; RELA,P. R. ; ALMEIDA-MURADIAN, L. B., MANCINIFILHO, J.; FREITAS, P.C.D. Effects of irradiation in medicinal and eatable herbs. Radiat. Phys. Chem. v. 63, p. 681-684, 2002.

87. KOZAKIEWCZ, Z; SMITH, D. Physiology of Aspergillus. In: SMITH. J.E (Ed). Aspergillus. Plenum Press, New York, 1994. p. 23-37.

88. LACEY, J. Pre and post-harvest ecology of fungi causing spoilage of foods and other stored products. IN: MOSS, M. O.; JARUIS, B.; SKINNER, F. A. (Ed.). Filamentous fungi in foods and feeds. Soc. Appl. Bacteriol. Symp. Ser., n. 18, p.145, 1989. 
89. LACEY, J. Water availability and the occurrence of toxigenic fungi and mycotoxins in stored products. In: INTERNATIONAL IUPAC SYMPOSIUM ON MYCOTOXINS AND PHYCOTOXINS, 6, Tokyo, 1988, p. 186-89.

90. LEVITSKI, R. G. \& KONIUKHOVA, V. B. On the toxicity of feed contaminated with common fungi. Veterinarya, v. 24, p. 40-43, 1947.

91. LIN, M. T.; DIANESE, J. C. A. coconut agar medium for rapid detection production by Aspergillus spp. Phytopathology, v. 66; p.1466-9, 1976.

92. LISKER, N.; MICHAELI, R.; FRANK, Z. R. Mycotoxigenic potential of Aspergillus flavus strains isolated from groundnuts growing in Israel. Mycopathologia, v. 122, p. 177-183, 1993

93. LUTOMSKY, J.; KEDZIA B. Mycoflora of crude drugs. Estimation of mold contaminations and their toxicity. Planta Med., v. 40, p. 212-217,1980.

94. MAITY, J.P.; CHAKRABORTY, A.; SAHA, A.; SANTRA, S.C.; CHANDA, S. Radiation-induced effects on some common storage edible seeds in India infested with surface microflora. Radiat. Phys. Chem. v. 71, p.1065-1072, 2004.

95. MARQUES, L. C.; PETROVICK, P. R. Normatização da Produção e comercialização de fitoterápicos no Brasil. IN: SIMÕES,C.M.O.; SCHENKEL, E. P.; GOSMANN, G.; MELLO, J. C. P.; MENTZ, L. A.; PETROVICK, P. R. (Ed.). Farmacognosia, da planta ao medicamento. Porto Alegre, Florianópolis, 2003.

96. MARTINS, H. M.; MARTINS, M. L.; DIAS, M. I.; BERNARDO, F. Evaluation of microbiological quality of medicinal plants used in natural infusions. Int. J. Food Microbiol., v. 68, p. 149-153, 2001.

97. MEHAN, V.K. \& CHOHAN, J. S. Aflatoxin $B_{1}$ producing of Aspergillus flavus Link ex Fries from cotton, maize and wheat. Mycopathol. M/fycol. Appl., v. 49 , p. $263-274,1973$.

98. MIRONENKO, N. V.; ALEKHINA, I. A.; ZHDANOVA, N. N.; BULAT, S. A. Intraspecific Variation in Gamma-Radiation Resistance and Genomic Structure in the Filamentous Fungus Alternaria alternata: A Case Study of Strains Inhabiting Chernobyl Reactor No. 4. Ecotoxicol. Environ. Safety, v. 45, p. 177-187, 2000.

99. MORS, W., Plantas Medicinais. Rev. Ciência Hoje, Rio de Janeiro, v. 1 n.3, p. $51-54,1982$. 
100. MOUSSA L. A. A. Effects of gamma- irradiation on actinomycetes containing some food and fodder products. 1988. Thesis (M.Sc.), Faculty of Science of Suez Canal University, Egypt.

101. MYUNG, W. B.; HONG, S. Y.; KYONG, S. K.; CHA, K. C. Effects of gamma irradiation on physiological effectiveness of Korean medicinal herbs. Radiat. Phys. Chem. v. 54, p. 291-300, 1999.

102. NORRED, W. P. Agriculturally important fungal toxins. Chem. Health \& Safety, Jul/Aug, 2000.

103. NORTHOLT, M. D.; VAN EGMOND, H. P.; PAULSCH, W. E. Differences between Aspergillus flavus strains in growth and aflatoxin production in relation to water activity and temperature. J. Food Prot. Des Moines, v. 40, p. $778-781,1977$.

104. NUNES, F. C. G. Avaliação microbiológica e toxigênica de chás e cápsulas usados como fitoterápicos na cidade de São Paulo, 2003. Dissertação (Mestrado) - Escola Paulista de Medicina, São Paulo.

105. ODAMTTEN, G.T.; APPIAH, V.; LANGERAK, D.I. Influence of inoculum size of Aspergillus flavus link on the production of aflatoxin $B_{1}$ in maize medium before and after exposure to combination treatment of heat and gamma radiation. Int. J. Food Microbiol. v. 4, p.119-127, 1987.

106. OLIVEIRA, C. A. F.; GERMANO, P. M. L. Aflatoxinas: conceitos sobre mecanismos de toxicidade e seu envolvimento na etiologia do câncer hepático celular. Rev. Saúde Publ., v. 31, n. 4, p. 417-424, 1997.

107. OLIVEIRA, J. A. A. Ocorrência de fungos filamentosos e de micotoxinas em ração destinada à alimentação de aves. 1996. Dissertação (mestrado) - Faculdade de Ciências dos Alimentos da Universidade Federal do Amazonas, Manaus.

108. PANIZZA. S. Plantas que curam: Cheiro de mato. 28.ed. São Paulo: IBRASA, 1997.

109. PHILLIPSON, J. D.. Phytochemistry and medicinal plants. Phytochemistry. v. 56, p. 237-245, 2001.

110. PIER, A. C. Mycotoxins and micotoxicoses. IN: BIBERSTEN, E. L.; ZEE, Y. C. (Eds.). Review of Veterinary Microbiology. Blackwell Scientific Publication, London, p. 348-355, 1990. 
111. PITT, J. I.; HOCKING, A. D.; GLENN, D. R. An improved medium for the detection of Aspergillus flavus and Aspergillus parasiticus. J. Appl. Bacteriol. v. 54, p. 109-114, 1983.

112. PITT, J. I.; MISCAMBLE, B. F. Water relations of Aspergillus flavus and closely related species. J. Food Prot., Des Moines, v. 58, p. 86-90, 1995.

113. PITT, J. I.; HOCKING, A. D. Fungi and Food Spoilage. 2.ed. Gaithersburg: Aspen Pub. Inc.,1999.

114. PITT, J. I.; BASILICO, J. C.; ABARCA, M. L.; LOPEZ, C. Mycotoxins and toxigenic fungi. Med. Mycol., v. 38, p. 41-46, 2000. Supplement 1.

115. POINTING, S.; JONES, E. B. G.; JONES, M. Radiosensitivity of fungi isolated from waterlogged archaeological wood. Mycoscience v. 37, p. 455458, 1996.

116. RAPER, K. B., FENNEL, D. I. In: WILLIAMS \& WILKINS, The genus Aspergillus. Baltimore, p.361-368, 1965.

117. RATES, S. M. K. Plants as source of drugs. Toxicon, v. 39, p. 603-613, 2001.

118. REDPATH, J. L.; PATTERSON, L. K. The effect of membrane fatty acid composition on the radiosensitivity of $E$. coli. Radiat. Res., v. 75, p. 443-447, 1978.

119. REIF, K.; METZGER, W. Determination of aflatoxins in medicinal herbs and plant extracts. J. Chromatogr. A., v. 692, p. 131-136, 1995.

120. RICHARD, J. L.; BENNETT, G. A.; ROOS, P. F.; NELSON, P. E. Analysis of naturally occurring mycotoxins in feedstuffs and food. J. Anim. Sci., v. 71, p. $2563-2574,1993$.

121. RIDELL, R. W., Permanent stained mycological preparation obtained by slide culture. Mycologia, v. 42, p.265-270, 1950.

122. RIZZO, I.; VEDOYA, G.; MAURUTTO, S.; HAIDUKOWSKI, M.; VARSAVSKY, E. Assessment of toxigenic fungi on Argentinean medicinal herbs. Microbiol. Res., v.159, p. 113-120, 2004.

123. ROCHA, L. O.; SOARES, M. M. S. R.; CORREA, C. L. Análise da contaminação fúngica em amostras de Cassia acutifolia Delile (sene) e Peumus boldus (Molina) Lyons (boldo-do-Chile) comercializadas na cidade de Campinas, Brasil. Braz. J. Pharm. Sci. v. 40, n.4, p. 522 - 523, 2004. 
124. ROMAGNOLI, B.; MENNA, V.; GRUPPIONI, N.; BERGAMINI, C. Aflatoxins in spices, aromatic herbs, herb-teas and medicinal plants marketed in Italy. Food Control, v. 18, p. 697-701, 2007.

125. ROWLEY, D. B.; SULLIVAN R.; JOSEPHSON, E. S. Indicators of viruses in food preserved by ionizing radiation. In: Indicators of Viruses in Water and Food. Gerald Berg (Ed.). Anne Arbor, Michigan, 1978.

126. ROY, A. K.; SINHA, K. K.; CHOURASIA, H. K. Aflatoxin Contamination of Some Common Drug Plants. Appl. Environ. Microbiol. v. 54, n.3, p. $842-$ 843, 1988.

127. RUSTOM, I. Y. S. Aflatoxin in food and feed: occurrence, legislation and inactivation by physical methods. Food Chemistry, v. 59, n. 1, p. 57-67, 1997.

128. SALAMA, A. M.; ALI, M. I.; EL-KIRDASSY, Z. H.; ALI, T. M. A study on fungal radioresistance and radiosensitivity. Zbl. Baket. Abt. // Bd. v. 132, p. $1-13,1977$.

129. SANTOS, P.R.V.; OLIVEIRA, A.C.X.; TOMASSINI, T.C.B. Controle microbiológico de produtos fitoterápicos. Rev. Farm. Bioquim. Univ. São Paulo, v. 31, p. 35-38, 1995.

130. SARDESAI, V. M. Herbal medicines: poisons or potions? J. Lab. Clin. Med., v. 139, p. 343-348, 2002.

131. SCHINDLER, A. F; PLAMER, J. G.; EISENBERG, W. V. Aflatoxin producing by Aspergillus flavus as related to various temperature. Appl. Microbiol., v. 15, p. 1006-1009, 1967.

132. SHARMA, A.; BEHERE, A.G.; PADWAL DESAI, S.R.; NADKARNI, G.B. Influence of inoculum size of Aspergillus parasiticus spores on aflatoxin production. Appl. Environ. Microbiol. v. 40, p. 989-993, 1980.

133. SHARMA, A.; GHANEKAR, A. S.; PADWAL-DESAI S. R.; NADKAMI, G. B. Microbiological status and antifungal properties of irradiated spices. J. Agric. Food Chem., v. 32, p. 1061-1063, 1984.

134. SHILO, Y. M. Toxic action of Aspergillus flavus in animal body. Sbornik Trudov Kharkowskogo Inst., v. 19, p. 63-73, 1940. 
135. SILVEIRA, V. D. Micologia. 5.ed. Rio de Janeiro: Editora da Universidade Federal Rural do Rio de Janeiro, 1995.

136. SIMÕES,C.M.O.; SCHENKEL, E. P.; GOSMANN, G.; MELLO, J. C. P.; MENTZ, L. A.; PETROVICK, P. R., Farmacognosia, da planta ao medicamento. 5.ed. Porto Alegre/ Florianópolis: Editora da UFRGS/ Editora da UFSC, 2003.

137. SOARES, L. M. V.; RODRIGUES - AMAYA, D. B. Survey of aflatoxins, ochratoxin A, zearalenone and sterigmatocystin in some Brazilian foods by using multitoxin thin-layer chromatographic. J. Assoc. Off. Anal. Chem., v. 72, p. 22-26, 1989.

138. SOMMER, N. F.; FORTLAGE, R.G. Ionizing radiation for control of postharvest diseases of fruits and vegetables. Adv. Food. Res. v. 51, 147-193, 1966.

139. SONAGLIO, D.; ORTEGA, G. G.; PETROVICK, P. R.; BASSANI, V. L. Desenvolvimento tecnológico e produção de fitoterápicos. In: SIMÕES, C. M. O.; SCHENKEL, E. P.; GOSMANN, G.; MELLO, J. C. P.; MENTZ, L. A.; PETROVICK, P. R., Farmacognosia, da planta ao medicamento, 5.ed. Porto Alegre/ Florianópolis: Editora da UFRGS/ Editora da UFSC, 2003.

140. SORIANI, R. R.; SATOMI, L. C.; PINTO, T. J. Effects of ionizing radiation in ginkgo and guarana. Radiat. Phys. Chem. v. 73, p. 239-242, 2005.

141. SMOLINSKE, S. C. Herbal product contamination and toxicity. J. Pharm. Pratice, v. 18, n. 13, p. 188-208, 2005.

142. STOLOFF, L., The three eras of fungal toxin research. J. Am. Oil Chem. Soc., v. 56, n. 9, p. $784-788,1979$.

143. SWEIHA H. E. Effect of gamma irradiation on certain soil inhibitant actinomycetes. 1984. Thesis (M.Sc.), Ain Shams Univ., Cairo, Egypt.

144. TASSANEEYAKUL, W.; RAZZAZI-FAZELI, E; PORASUPHATANA, S.; $\mathrm{BOHM}, J$. Contamination of aflatoxins in herbal medicinal products in Thailand. Mycopathologia, v. 158, p. 239-244, 2004.

145. TEIXEIRA, F. E. Natureza, um modismo na cultura alternativa. Pau Brasil, São Paulo, v. 7, p. 77-79, 1985.

146. THE PHARMACOPEIA OF THE UNITED STATES OF AMERICA (USP). $28^{a}$ ed. Rockville: United States Pharmacopeial Convention, 2005. 3013 p. 
147. VAN DER ZIJDEN et al. Isolation in crystalline form of a toxin responsible for turkey $X$ disease. Nature, London, v. 195, p. 1062, 1962.

148. VAN DYCK, P. J.; TOBBACK, P.; FEYS, M.; VAN DE VORDE, $H$. Sensitivity of Aflatoxin $\mathrm{B}_{1}$ to lonizing Radiation. Appl. Environ. Microbiol., v. 43, p. 1317-1319, 1982.

149. VEIGA JÚNIOR, V.F.; PINTO, A. C. ; MACIEL, M.A.M. Plantas medicinais: cura segura? Química Nova, São Paulo, v. 28, p. 519-528, 2005.

150. WHO - World Health Organization. Safety and nutritional adequacy of irradiated food, p.1-17, World Health Organization, Geneva, 1994.

151. WHO - World Health Organization. Quality control methods for medicinal plant materials. (ISBN 924154510 0). Printed in England. Geneva 1998.

152. WYLLIE, T. D.; MOREHOUSE, L. G. Mycotoxic fungi, mycotoxins and mycotoxicoses: mycotoxic fungi and chemistry of mycotoxins. New York: Marcel Dekker, v. 1, p. 537, 1977.

153. YANG, M. H.; CHEN, J. M.; ZHANG, X. H. Immunoaffinity column clean-up and liquid chromatography with post-column derivatization for analysis od aflatoxin in traditional Chinese medicine. Chromatographia, 2005.

154. YOSHISAWA, T. General View on Mycotoxins. Text Book for Group Training Course in Mycotoxin Inspection in Food. JICA, 1999. p. 5 - 22.

155. YOUNG, B.Y.; ILL, Y. J.; HAE, R. P.; HEON, O.; UHEE, J.; SUNG, K. J. Toxicological safety and stability of the components of an irradiated Korean medicinal herb, Paeoniae Radix. Radiat. Phys. Chem. v. 71, p. 115-119, 2004.

156. ZARONI, M. ; PONTAROLO, R, ; ABRAHÃO, W. S. M. ; FÁVERO, M. L. D. ; CORREA JÚNIOR, C. ; STREMEL, D. P. Qualidade microbiológica das plantas medicinais produzidas no Estado do Paraná. Rev. Bras. Farmacogn., v. 14, n. 1, p. 29-39, 2004.

157. ZEVADA, M. Z. Producción de aflatoxinas por cepas aisladas de maiz. Rev. Lat-Am. Microbiol., v. 13, p. 263-266, 1971.

158. ZHDANOVA, N. N.; VASILEVSKAYA, A. I.; ARTYSHKOVA, L. V.; SADOVNIKOV, YU. S.; LASHKO, T. N.; GAVRILYUK, V. I.; DIGHTON, J. Changes in micromycete communities in soil in response to pollution by long- 
lived radionuclides emitted in the Chernobyl accident. Mycol. Res., v. 98, p. 789-795, 1994. 